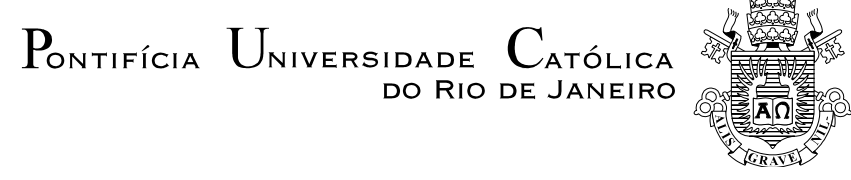

Julio Mendes de Assis

PRÉ-VESTIBULAR COMUNITÁRIO POMPEIA
SANTO AGOSTINHO: História e Significados
na Perspectiva dos Precursores

Dissertação de Mestrado

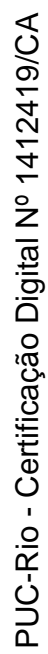

Orientadora: Prof . Andréia Clapp Salvador

Dissertação apresentada ao Programa de PósGraduação em Serviço Social da PUC-Rio como requisito parcial para a obtenção do título de Mestre em Serviço Social.

Rio de Janeiro Setembro de 2016 


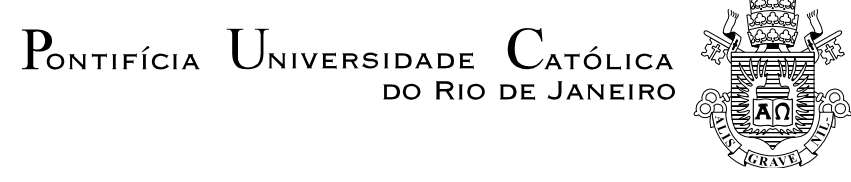

Julio Mendes de Assis

\title{
PRÉ-VESTIBULAR COMUNITÁRIO POMPEIA SANTO AGOSTINHO: História e Significados na Perspectiva dos Precursores
}

Dissertação apresentada como requisito parcial para obtenção do grau de Mestre pelo Programa de PósGraduação em Serviço Social do Departamento de Serviço Social do Centro de Ciências Sociais da PUCRio. Aprovada pela Comissão Examinadora abaixo assinada.

\author{
Prof ${ }^{a}$ Andréia Clapp Salvador \\ Orientador \\ Departamento de Serviço Social - PUC-Rio \\ Profo Jose Carmello Braz de Carvalho \\ PUC-Rio \\ Profo Ramofly Bicalho dos Santos \\ UFRRJ \\ Prof ${ }^{a}$ Valeria Pereira Bastos \\ PUC-Rio \\ Prof $f^{a}$ Mônica Herz \\ Vice-Decana de Pós-Graduação do \\ Centro de Ciências Sociais - PUC-Rio
}

Rio de Janeiro, 01 de setembro de 2016 
Todos os direitos reservados. É proibida a reprodução total ou parcial do trabalho sem autorização da universidade, da autora e do orientador.

\title{
Júlio Mendes de Assis
}

Graduou-se em Serviço Social na PUC-Rio (Pontifícia Universidade Católica do Rio de Janeiro) em 2011. É Mestrando em Serviço Social da PUC-Rio (2016). É Assistente Social na Arquidiocese do Rio de Janeiro. Professor Titular da Disciplina de Cultura e Cidadania do Pré-Vestibular Comunitário Pompeia Santo Agostinho (2009-2016). É Presidente da Rede de Cultura e Cidadania Ricardense (2013-2016).

\section{Ficha Catalográfica}

\author{
Assis, Julio Mendes de \\ PRÉ-VESTIBULAR COMUNITÁRIO POMPEIA \\ SANTO AGOSTINHO: História e Significados na \\ Perspectiva dos Precursores / Julio Mendes de Assis; \\ orientadora: Andréia Clapp Salvador. - 2016.
}

94 f. : il. color. ; $30 \mathrm{~cm}$

Dissertação (mestrado)-Pontifícia Universidade Católica do Rio de Janeiro, Departamento de Serviço Social, 2016.

Inclui bibliografia.

1. Serviço social - Teses. 2. Pré-vestibular comunitário. 3. Movimento social. 4. Educação popular. 5. Cidadania participativa. I. Salvador, Andréia Clapp. II. Pontifícia Universidade Católica do Rio de Janeiro. Departamento de Serviço Social. III. Título. 
Dedico este trabalho aos fundadores, Pe. Antônio Garcia Alonso (in memória), Heros Santos, Rafael Dias, coordenadores, professores voluntários e todos os alunos do Curso Pré-Vestibular Comunitário Pompeia Santo Agostinho. 


\section{Agradecimentos}

A conclusão desta dissertação de mestrado significa que se aproxima o final de mais um ciclo importante na minha vida. Esse trabalho foi realizado com grande alegria e satisfação.

Entretanto alguns obstáculos tiveram de ser superados durante esse processo, problemas de saúde na família, conciliar os estudos com os horários de trabalho. Definitivamente conciliar a vida acadêmica e a vida laborativa é um grande desafio.

Assim, percorrer esse caminho só foi possível porque em nenhum momento estive sozinho, por isso meus sinceros agradecimentos a todos que de alguma forma participaram da construção deste trabalho.

Em primeiro lugar, agradeço à minha família, minha mãe Alzira Emília e minhas filhas Maria Luísa e Anna Elísa. Vocês são a razão da minha vida e tudo que eu faço é pensando em cada uma de vocês.

À minha orientadora Andréia Clapp Salvador, pela parceria de sempre, uma companheira que não se limitou à orientação acadêmica, mas - mesmo com tantas atribuições - esteve presente o tempo todo. Obrigado também pelo compartilhamento dos sonhos e angústias que também fizeram parte dessa trajetória. Não tenho palavras para agradecer a você.

Aos professores do Departamento de Serviço Social da PUC-Rio, por quem tenho grande admiração e respeito pelo trabalho de excelência tanto na graduação como na Pós. Destaco a professora Luiza Helena Nunes Hermel, por ter me incentivado em relação ao tema, a professora Sueli Bulhões, que foi minha orientadora na graduação e me fez despertar interesse pela pesquisa, e a professora Valéria Pereira Bastos, por quem tenho grande admiração e exemplo na profissão. 
Aos caríssimos funcionários do departamento de Serviço Social da PUC-Rio, que estão sempre prontos a nos atender e orientar quando precisamos.

Aos digníssimos professores José Carmelo Braz de Carvalho, Ramofly Bicalho dos Santos e Valéria Pereira Bastos, meus sinceros agradecimentos pela disponibilidade em participar da banca examinadora e pelas contribuições que certamente enriquecerão este trabalho.

Aos colegas de turma pela troca constante dos saberes e pelo prazer de dividir com vocês a sala de aula. Especialmente agradeço à minha querida amiga Thamires da Silva Ribeiro, parceira de luta e caminhada.

Às queridas amigas Geovana Silva, Denise Barros, Luciana Azevedo, Elaine Cubeiro e Tainah Rosa Resplande pela amizade, carinho, admiração e incentivo nessa empreitada. Da mesma forma agradeço ao amigo irmão Anderson Torres pela parceria de sempre.

Enfim, aos companheiros da Rede de Cultura e Cidadania Ricardense pela compreensão nos momentos da minha ausência e pelo compromisso com a nossa comunidade. Poder contar com vocês é muito importante. 


\section{Resumo}

Assis, Julio Mendes; Salvador, Andréia Clapp. PRÉ-VESTIBULAR COMUNITÁRIO POMPEIA SANTO AGOSTINHO: História e Significados na Perspectiva dos Precursores. Rio de Janeiro, 2016. 94p. Dissertação de Mestrado - Departamento de Serviço Social, Pontifícia Universidade Católica do Rio de Janeiro.

O objetivo deste trabalho é fazer a constituição histórica do Curso PréVestibular Comunitário Pompeia Santo Agostinho - CPVCPSA na perspectiva dos precursores. Parte-se do pressuposto que os implementadores do projeto tiveram como influências ou referências movimentos sociais de educação popular, que precederam o CPVCPSA, como o Pré-Vestibular para Negros e Carentes PVNC, que tem similaridade com o pré-vestibular em questão. No entanto, assim como o PVNC, o CPVCPSA também tem como base a Igreja Católica e, no caso do CPVCPSA, este funciona - até os dias de hoje - na paróquia Nossa Senhora do Rosário de Pompeia, situada no bairro de Ricardo de Albuquerque, subúrbio do Rio de Janeiro. Para alcançar o objetivo proposto por esse estudo - e com base na pesquisa de campo - optou-se pela metodologia descritiva e de natureza qualitativa. Para coleta de dados, optou-se pela aplicação de um questionário semiestruturado junto aos precursores, isto é, cinco professores voluntários que ingressaram no "pré", no período de 2001 a 2005, pelo fato de considerarmos esse período como de consolidação do "pré". Posterior à coleta de dados, foi feita a análise das entrevistas e - concomitante à revisão bibliográfica - observamos as motivações que os precursores tiveram para regressar como professor voluntário neste pré-vestibular comunitário, após terem sido alunos do "pré". Ao final do estudo, constatou-se que as motivações dos precursores têm como base o sentido de pertencimento à comunidade local, os laços afetivos que foram construídos e o desejo de contribuir para dar continuidade às atividades do CPVCPSA. Concluiuse também que o significado dessa experiência perpassou a questão da cidadania participativa dos sujeitos, já que os entrevistados da pesquisa, a partir da inserção no Pré-Vestibular, se tornaram agentes multiplicadores e "personalidades emblemáticas". As entrevistas evidenciaram que os precursores traziam trajetórias de sucesso e que o compromisso com a transformação da realidade dos alunos gerou principalmente rebatimentos positivos no próprio pré-vestibular comunitário, na família, na comunidade e no bairro de um modo geral. 


\section{Palavras-chave}

Pré-Vestibular Comunitário; Movimento Social; Educação Popular; Cidadania Participativa.

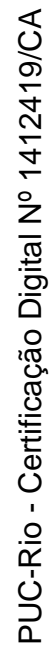




\section{Abstract}

Assis, Julio Mendes; Salvador, Andréia Clapp (Advisor). PREVESTIBULAR COMMUNITY POMPEIA SAINT AUGUSTINE: History and Meaning in the Perspective of Precursors. Rio de Janeiro, 2016. 94p. MSc Dissertation - Departamento de Serviço Social, Pontifícia Universidade Católica do Rio de Janeiro.

The objective of this present work it is to make the historical constitution of the Community Pre-College Course Pompeii St. AugustineCPVCPSA the perspective of precursors. This is on the assumption that the implementers of the project had as influences or references social movements of popular education that preceded the CPVCPSA, as the Pre-College for Blacks and Needy - PVNC, which has similarity to the pre-university in question. However, as the PVNC the CPVCPSA also it is based on the Catholic Church and, in the case of CPVCPSA, this works to nowadays, in the parish of Our Lady of Pompeii Rosary, located in Ricardo de Albuquerque neighborhood, suburb of Rio de Janeiro. To achieve the goal proposed by this study, and based on field research, we chose the methodology descriptive and qualitative. To data collect was chosen by applying a semi-structured questionnaire with the precursors, this is, five volunteer teachers who joined the "pre" from 2001 to 2005, because we consider this period as the consolidation of the "pre". After the data collection, analysis was made of the interviews and, while after the bibliographic review, We observe the motivations that had precursors. They had to join as a volunteer teacher in this community pre-university, after being students of the "pre". At the end of the study, it was found that the motivations of precursors are based on the sense of belonging to the local community, the emotional bonds that have been built and the desire to contribute to continue the CPVCPSA activities. It was also concluded that the meaning of this experience pervaded the issue of participatory citizenship of the subjects, as the survey respondents from the inclusion in the Pre-College, became multipliers and "emblematic personalities." The interviews showed that the precursors brought successful careers and commitment to the transformation of students' reality, generated mostly positive repercussions on the Community pre-university itself, in the family, community and in the general neighborhood. 


\section{Keywords}

Pré-Vestibular Comunity; Social Movements; Popular Education; Participatory Citizenship

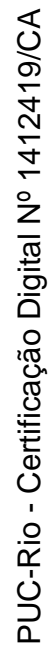




\section{Sumário}

1 Introdução

2 Pré-Vestibulares para Negros e Carentes - PVNC 22

2.1 Pré-Vestibular para Negros e Carentes: O que é a História? 22

2.2 Pré-Vestibular para Negros e Carentes e os Movimentos Sociais 28

2.3 Os Cursos Pré-Vestibulares Comunitários - CPVCs 36

2.3.1 Os Cursos Pré-Vestibulares Comunitários com base na Igreja

Católica

2.4 Políticas de Ação Afirmativas Como Mecanismo de Inclusão dos

Cursos Pré-Vestibulares Comunitários - Populares

3 Curso Pré-Vestibular Comunitário Pompeia Santo Agostinho -

CPVCPSA: O Locus da Pesquisa

3.1 Os Precursores do Curso Pré-Vestibular Comunitário Pompeia Santo Agostinho - O Perfil dos Entrevistados

3.2 A História do Curso Pré-Vestibular Comunitário Pompeia Santo Agostinho

- A sua gênese e formação

3.3 As Motivações dos Protagonistas do Curso Pré-Vestibular Comunitário Pompeia Santo Agostinho

3.4 Principais Influências e Referências dos Precursores do Curso Pré-

Vestibular Comunitário Pompeia Santo Agostinho

3.5 O Significado da Participação no Curso Pré-Vestibular Comunitário

Pompeia Santo Agostinho - Uma experiência de vida

3.6 A Importância do Curso Pré-Vestibular Comunitário Pompeia Santo Agostinho - O olhar dos seus protagonistas 
4 Considerações Finais

5 Referências bibliográficas

89

6 Anexo 1: Roteiro De Entrevista

7 Anexo 2: Apêndice A 


\section{Lista de Tabelas e Figuras}

Gráfico 1 - Sexo $\quad 54$

Gráfico 2 - Declaração de Cor 54

Gráfico 3 - Local de moradia no período do Pré-Vestibular 55

Gráfico 4 - Religião 55

Gráfico 5 - Idade no momento da Pesquisa (Janeiro 2016) 56

Gráfico 6 - Escolaridade Atual 57 


\section{Lista de Siglas}

ALERJ - Assembleia Legislativa do Estado do Rio de Janeiro

CEB's - Comunidades Eclesiais de Base

CELAM - Conferência Episcopal Latina Americana

$\mathrm{CF}$ - Constituição Federal

CPVCs - Cursos Pré-Vestibulares Comunitários

CPVCPSA - Curso Pré-Vestibular Comunitário Pompeia Santo Agostinho

EDUCAFRO - Educação e Cidadania De Afrodescendentes

ENEM - Exame Nacional do Ensino Médio

JAC - Juventude Agrária Católica

JEC - Juventude Estudantil Católica

JIC - Juventude Independente Católica

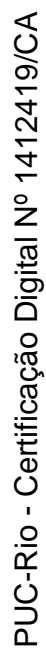

JOC - Juventude Operária Católica

JUC - Juventude Universitária Católica

MEC - Ministério da Educação e Cultura

ONG - Organização Não Governamental

PJ - Pastoral da Juventude

ProUni - Programa Universidade para Todos

PUC - Pontifícia Universidade Católica

PVC - Pré-Vestibular Comunitário

PVNC - Pré-Vestibulares Para Negros e Carentes

Sisu - Sistema de Seleção Unificada

TL - Teologia da Libertação

UERJ - Universidade Estadual do Rio de Janeiro

UENF - Universidade do Norte Fluminense 


\section{1 \\ Introdução}

No Brasil, os Pré-Vestibulares Comunitários ou Populares tiveram no período de redemocratização do país um momento fértil, em que houve uma grande disseminação desse movimento de educação popular, cujo objetivo principal era a inclusão de negros e pobres nas universidades brasileiras. Havia também na esfera política da sociedade a participação de lideranças desses movimentos, que buscavam pressionar o Estado brasileiro com a cobrança de políticas públicas como mecanismos de inclusão de negros e pobres no ensino superior.

Entre os movimentos de educação popular, o Pré-Vestibular para Negros e Carentes - PVNC foi uma experiência exitosa, que surgiu no início da década de 1990, na Baixada Fluminense do Rio de Janeiro. O PVNC foi fundado por algumas lideranças da Igreja Católica, Frades Franciscanos - da Pastoral Afro e também de militantes do Movimento Negro, que não pertenciam à Igreja Católica. Essa experiência foi rapidamente disseminada e houve uma rápida multiplicação dos núcleos do PVNC, principalmente na região metropolitana do Rio de Janeiro.

Os dois grupos que disputavam a direção do PVNC, o campo eclesial ligado à Igreja Católica e o Campo Negro, que tinha na frente os militantes do Movimento Negro, não conseguiram chegar a um acordo em relação à direção política e ideológica do PVNC e, por isso, houve uma dissidência no movimento, resultando na criação da EDUCAFRO, Educação e Cidadania de Afrodescendentes, por parte do grupo ligado à Igreja Católica.

Não obstante à dissidência, o PVNC influenciou muitos grupos que surgiram neste período, devido à sua trajetória exitosa tornou-se referência até mesmo para os grupos que não tinham a questão racial como bandeira principal de luta, mas que tinham a democratização da educação no ensino superior como ponto em comum com o PVNC.

Em 2001, nasce nas dependências da Paróquia Nossa Senhora do Rosário de Pompeia (Igreja Católica) o Pré-Vestibular Comunitário Pompeia Santo Agostinho CPVCPSA, localizado em Ricardo de Albuquerque, no subúrbio do Rio de Janeiro. Ao longo desses 15 anos de funcionamento, este Pré-Vestibular Comunitário possibilitou - 
com a sua ação - que vários alunos ingressassem no ensino superior e realizassem o sonho de cursar uma faculdade.

Durante este período, não foram realizadas pesquisas e estudos que buscassem elucidar como se deu o processo de constituição do CPVCPSA. Sendo assim, sente-se a necessidade de realizar um estudo com objetivo de compreender as questões acerca dos protagonistas dessa histórica.

A motivação para realizar investigação desta natureza nasce a partir da minha inserção no CPVCPSA como professor da disciplina de Cultura e Cidadania, posteriormente como Assistente Social e membro da coordenação do "pré". Isso me possibilitou a aproximação com as questões do campo empírico e despertou o interesse do pesquisador para investigar como se deu o processo de constituição do pré-vestibular comunitário. Sendo assim, juntou-se o engajamento político com o estímulo de pesquisador para realização desse trabalho.

Será destacada nesse estudo a atuação dos professores voluntários que tiveram sua inserção nos cinco primeiros anos do "pré" (2001 - 2006), por considerarmos como os anos de consolidação do CPVCSA. Nesse processo, os professores voluntários, assim como os coordenadores, desempenham funções fundamentais para o funcionamento do PVC. Sem eles não há continuidade do projeto e o PVC deixa de existir. Em especial, os ex-alunos que após se inserirem na universidade regressam para o "pré”, para serem voluntários como professores, coordenadores, entre outras funções. Conforme destaca Santos (2005):

Assim, os pré-vestibulares acabam por se constituir em um espaço público de socialização, um ator plural (ou ideologicamente plural), no qual se torna possível, através do múltiplo pertencimento, a recomposição de identidades coletivas em um cotidiano onde a democracia (essencialmente conflitiva) é radicalizada - as decisões são coletivas e os papéis são múltiplos e fundidos, alunos podem ser (e muitas vezes são) coordenadores, professores, etc. (Santos: 2005; pág. 193).

Considerando que o CPVCSA completou 15 anos de fundação em 2016, faz-se necessário investigar as motivações que esses professores voluntários tiveram para atuar no PVC, tendo em vista que a maioria dos professores voluntários dos "prés" é graduando ainda no início de sua trajetória acadêmica e tem no PVC a primeira experiência na docência. Neste contexto, os PVCs tornaram-se um espaço privilegiado de formação de professores, pois devida à carência de professores das mais variadas 
disciplinas exigidas para o exame do vestibular, o "pré" serve como estágio de docência antecipado.

Segundo Santos:

(...) A autonomia vai, desta forma, se constituir em um princípio orientador dos mecanismos de agregação, com um impacto direto sobre a construção dos projetos e da prática pedagógica que, diante do não controle, vão fazer da inovação e da criação a tônica do ensinar nos pré-vestibulares: cada professor "cria" seu projeto, sua prática pedagógica, sua metodologia, suas atividades, ainda que com variados graus de liberdade. Os "prés" vêm funcionando, desta feita, como importante espaço de formação de professores, tendo vista que grande parte deles tem seu corpo docente composto majoritariamente por estudantes de graduação em cursos de licenciatura, que vivem, nos "prés", sua primeira experiência docente. (Santos: 2005; Págs 193 e 194).

Somada esta autonomia na criação pedagógica das aulas nos "prés" à singularidade dos alunos, que são majoritariamente alunos da rede pública de ensino, os PVs tornaram-se um espaço singular de iniciação da profissão de professor e de formação de educadores populares.

A relevância deste estudo decorre do compromisso desses atores sociais, no sentido de ratificar a importância da continuidade das atividades do CPVCSA para as pessoas que almejam cursar o ensino superior, o significado dessa conquista para as famílias dessas pessoas e a importância desse projeto para a comunidade da Pompeia.

Com a pesquisa, espera-se responder a questão central deste estudo, que consiste em Identificar como se deu o processo de constituição do Curso Pré-Vestibular Comunitário Pompeia Santo Agostinho - CPVCPSA, tendo como ponto de partida a perspectiva dos seus precursores.

Além disso, outras questões que a pesquisa também busca compreender são: as motivações dos precursores do CPVCPSA, identificar as influências e referências que levaram esses sujeitos a atuarem como voluntários no período de consolidação do projeto e assim compreender a importância desse projeto para comunidade da Pompeia e para o bairro de Ricardo de Albuquerque.

Compõem esta dissertação, além desta introdução, dois capítulos e as considerações finais.

No capítulo 2, optou-se pela construção de todo arcabouço teórico que está dividido em três subcapítulos. Estes discorrem: a primeira parte sobre o PVNC, a 
segunda parte sobre os Cursos Pré-Vestibulares Comunitários e a terceira parte sobre as Políticas de Ação Afirmativa.

Vale ressaltar que - para estudar os pré-vestibulares populares - faz-se necessário ter um olhar atento para a história do PVNC, pois este movimento é uma referência no que tange aos movimentos de educação popular, sobretudo os que ganharam mais visibilidade a partir da década de 1990. Além disso, abordou-se o PVNC enquanto movimento social, haja vista que no Pós-Constituição de 1988, criou-se um ambiente de efervescência no Brasil para os "novos movimentos sociais" (Clapp 2011), por colocarem na agenda política do país antigas demandas e novas reinvindicações.

Na segunda parte do capítulo 2, observou-se os Cursos Pré-Vestibulares Comunitários - CPVCs, pois houve uma grande disseminação desta vertente, sobretudo os que surgiram vinculados à Igreja Católica. É importante destacar que - quando houve a dissidência no PVNC e o advento da EDUCAFFRO - alguns grupos que se desvincularam do PVNC passaram a utilizar o termo "comunitário", como é o exemplo do Pré-Vestibular Comunitário da Rocinha. Entretanto isto não significa uma negação da questão racial, mas o termo "comunitário" agregava mais por representar uma maior diversidade do perfil dos alunos destes "prés".

Na terceira parte do capítulo 2, disserta-se sobre as Políticas de Ação Afirmativa como mecanismo de inclusão dos CPVCs-Populares, onde se destaca a participação dos movimentos de educação popular na luta pelas conquistas dessas políticas. Nesta parte, também são ressaltadas outras experiências de ação afirmativa que contaram com a participação dos PVCs, como exemplo, a Ação Afirmativa na PUC-Rio.

No capítulo 3, optou-se por fazer a apresentação do Campo da Pesquisa, o perfil dos entrevistados e a análise dos dados da pesquisa com apresentação dos resultados alcançados neste estudo. Este capítulo começa discorrendo sobre a gênese do CPVCPSA, a história e a identificação dos precursores do PVC, em seguida o capitulo é subdividido em quatro partes, a saber: a primeira parte é referente às motivações dos protagonistas da história, que são os professores voluntários; a segunda parte discorre sobre as referências e influências dos precursores; e a terceira parte apresenta os significados da experiência como professores voluntários do CPVCPSA, por fim, este capítulo versa sobre a representatividade do CPVCPSA para os precursores.

E, por conseguinte, seguem-se as Considerações Finais no capítulo 5. 


\section{Nota Metodológica}

Tomando como objeto de estudo a constituição do processo de formação do Curso Pré-Vestibular Comunitário Pompeia Santo Agostinho e, por conseguinte, a análise das motivações dos professores voluntários que ingressaram nos cinco primeiros anos do PVC - período de consolidação do projeto -, apresenta-se a seguir a metodologia utilizada para o desenvolvimento da pesquisa.

A metodologia é o caminho que foi percorrido para que pudéssemos alcançar os objetivos traçados inicialmente. Este caminho foi percorrido obedecendo algumas etapas pertinentes à pesquisa social, isto é, definição do referencial teórico, construção do projeto de qualificação, elaboração do roteiro de entrevista, as entrevistas propriamente ditas, a organização e análise do material coletado. Enfim, as fases que devem ser observadas para que a pesquisa seja concluída com êxito.

E, ademais, é importante ressaltar que durante todo o processo da pesquisa foram feitas a revisão permanente da bibliografia e a sistematização da literatura referente às categorias de análise: 1- Pré-Vestibulares Comunitários - Populares e 2Políticas de Ação Afirmativa.

Faz-se necessário destacar que a inserção do pesquisador no campo empírico foi importante para a formulação do problema (questão central), a definição dos objetivos e posteriormente a identificação dos sujeitos da pesquisa.

Para alcançar o objetivo proposto pelo estudo e com base nas observações da realidade do campo empírico, optou-se pela realização de uma pesquisa descritiva, de natureza quanti-qualitativa. Contudo trata-se da perspectiva descritiva que não se limita à simples identificação da existência entre variáveis, mas a pesquisa descritiva quando a partir de seus objetivos acaba servindo para proporcionar uma nova visão do problema.

Segundo Gil,

As pesquisas deste tipo têm como objetivo primordial a descrição das características de determinada população ou fenômeno ou estabelecimento de relações entre variáveis. São inúmeros os estudos que podem ser classificados sob este título e uma de suas características mais significativa está na utilização de técnicas padronizadas de coleta de dados. (1999: pág. 44). 
Para a realização das entrevistas, optou-se pela construção de um roteiro de entrevista (vide anexo), com perguntas abertas e fechadas e as mesmas foram realizadas durante os meses de janeiro e fevereiro de 2016.

Para selecionar o universo a ser pesquisado, no primeiro momento foi feita abordagem direta com a atual coordenação do PVC. No segundo momento, pode-se observar o evento denominado Semana de Debate Universitário, realizado anualmente pelo CPVCPSA, onde muitos ex-alunos e professores regressam ao PVC para participar. Desta forma, pode-se identificar o universo a ser pesquisado, isto é, dois coordenadores e cinco professores voluntários, totalizando 07 pessoas.

O recorte temporal foi estabelecido pelo fato de compreender um período de consolidação do PVC nos 05 anos iniciais, de 2001 a 2006, conforme já mencionado neste estudo.

Quanto à localização dos entrevistados e o agendamento das entrevistas, não houve maiores dificuldades, pois a maioria ainda reside nos bairros da época em que atuavam no CPVCSA, isto é, Ricardo de Albuquerque e Parque Anchieta. Desta forma, três (3) entrevistas foram realizadas em pré-vestibulares comunitários, duas (2) no Pompeia Santo Agostinho e uma (1) no CPVC Santa Teresa D’Ávila, uma (1) entrevista foi feita em um espaço neutro e apenas uma (1) entrevista não foi realizada presencialmente "in locus", porque a entrevistada mora na França e o questionário foi enviado por e-mail.

Entretanto vale ressaltar que não foi possível realizar as entrevistas com os três (03) fundadores que foram identificados, sendo que dois (2) não aceitaram o convite por motivos pessoais e um (1) por motivo de falecimento. Contudo este fato não comprometeu os objetivos desse estudo.

Após a realização das entrevistas, foi feita a transcrição, a sistematização e a análise do material, com o uso das categorias indicadas neste projeto e depreendidas da exploração do material colhido. À luz do referencial teórico sistematizado na pesquisa bibliográfica, destacaram-se as categorias Pré-Vestibulares Comunitários ou Populares e Política de Ação Afirmativa, além de outras categorias subjacentes ao objeto da pesquisa, tais como os conceitos de José Murilo de Carvalho, "cidadania participativa" e Evaline Dagnino, "nova cidadania”. 
À luz desse referencial teórico, analisou-se a perspectiva dos entrevistados quanto às motivações dos professores voluntários para atuarem no CPVCSA e as influências e/ou referências que eles tiveram no processo de constituição do projeto social.

Enfim, para a análise e organização dos dados coletados, e a elaboração da dissertação em si, contou-se com o processo de orientação constante, assim como em todo o período de desenvolvimento da mesma. É importante destacar que o tempo - para que todo o processo fosse concluído - é muito curto e isso dificultou o aprofundamento de questões transversais que surgiram ao longo da pesquisa, que não fazem parte dos objetivos desse estudo. 


\section{2 \\ Pré-Vestibulares para Negros e Carentes - PVNC}

O Pré-Vestibular para Negros e Carentes - PVNC é uma das experiências mais exitosas da história recente do Brasil, sobretudo no que tange ao campo social na nova República ou recente redemocratização do país, pois de acordo com o material pesquisado, o primeiro núcleo do PVNC é fundado no ano de 1993, na Baixada Fluminense do Rio de Janeiro. No entanto não podemos ter o risco de compreender o PVNC somente como um cursinho preparatório para que alunos negros e pobres possam prestar o exame do vestibular.

O PVNC não se limita à questão do ensino e aprendizagem, pois sua atuação também se dá no campo político, isto é, nos espaços públicos de participação social e militância política. Contudo essa característica faz do PVNC um movimento social de educação popular, que já no início de suas atividades expandiu rapidamente o número de seus núcleos e posteriormente serviu de referência para formação de diversos cursos com proposta semelhante à do PVNC ou não.

\section{1}

\section{Pré-Vestibular para Negros e Carentes: O que é a História?}

O Pré-Vestibular para Negros e Carentes - PVNC é um movimento de educação popular conhecido em todo Brasil, pois o movimento que tem como principal bandeira a inserção de negros e pobres no ensino superior ganhou notoriedade no cenário político brasileiro desde a sua fundação na década de 1990.

De acordo com os autores que se dedicam a pesquisar o tema dos PréVestibulares Populares-PVPs, as primeiras experiências surgidas no Brasil datam da década de 1970. Entretanto foi na virada da década de 1980 para a década de 1990 que há registros do surgimento de um número expressivo de núcleos do PVNC. Este período histórico é conhecido como o de redemocratização do país, por ser após a promulgação da Constituição de 1988. Contudo merece destaque o PVNC, pois entre os movimentos que surgiram neste período, foi o PVNC que congregou o maior número de núcleos fundados nesse período. 
Segundo Santos (2003),

A ideia da constituição de cursos pré-vestibulares para grupos socialmente desfavorecidos remonta, pelo menos, à década de 1970. Nascimento (2002) localiza em 1976 a criação de um curso voltado para negros, organizado pelo Centro de Estudos Brasil-África no Rio de Janeiro. Na década de 1980 também foram criados outros cursos, mas foi na década seguinte que ocorreu uma difusão massiva desta iniciativa. A expressão mais importante desse processo foi o Pré-Vestibular para Negros e Carentes (PVNC), pelo número de núcleos que criou e congregou, e pelo seu caráter seminal muitos cursos, mesmo que desvinculados dele, surgiram a partir da ação direta ou influência de seus militantes, difundindo seu formato e alguns de seus princípios organizativos e ideológicos. O PVNC constituiu uma rede que chegou a articular mais de setenta cursos pela região metropolitana do Rio de Janeiro. (pág. 130).

O PVNC catalisou vários movimentos que tinham em comum a bandeira da questão racial. Alguns autores destacam que o PVNC nasce no início da década de 1990, com congruência do Movimento Negro e da Pastoral Afro da Igreja Católica, sobretudo com a liderança dos Frades Franciscanos, na Baixada Fluminense - Rio de janeiro.

Segundo Carvalho:

Em 1988, a Campanha da Fraternidade suscita, entre as Pastorais Juvenis, iniciativas em prol da cidadania educacional entre a juventude negra, consolidadas a partir de 1993 na Baixada Fluminense, no âmbito das ações dos Frades Franciscanos nos PVNCs - prévestibulares para negros e carentes (Revista Proposta/Fase, 2001). Na Bahia, antes mesmo de 1994, havia a experiência de um pré-vestibular para negros, Grupo Stive Biko, e nesse ano lá ocorreu o SENUM, um congresso de estudantes negros dissidentes da UNE. Já no contexto universitário da USP consolida-se, após 1996, o Núcleo da Consciência Negra (Andrade, 2002). Desde esses primórdios, os embriões dos CPVCs afirmaram-se crescentemente como um movimento social de cidadania ativa, inclusão social e resgate de uma dívida que o Brasil tem, historicamente, com a sua população afrodescendente. (2005, pág. 24).

$\mathrm{O}$ autor faz um resgate histórico da gênese do PVNC, contextualizando os fatores que favoreceram a criação do movimento. Esses fatores são no âmbito das pastorais e organizações da Igreja Católica, pois essas organizações foram importantes na composição da base fundante do PVNC.

Outra questão importante para compreender o início da trajetória do PVNC são as influências que serviram de referência ideológica e direção política para os fundadores do PVNC. Entre as principais referências estão os grupos ligados à Igreja 
Católica e organizações ligadas ao Movimento Negro. Neste contexto, vale ressaltar algumas dessas referências.

Segundo Santos (2003):

O primeiro núcleo do PVNC foi criado em São João de Meriti - na Baixada Fluminense - em 1993, fruto de debates que já se desenvolviam alguns anos antes, por grupos ligados aos Agentes da Pastoral do Negro (APNs), ligados à militância católica de corte racial, juntamente com outros movimentos eclesiais de corte semelhante, como o Greni (Grupo de Reflexão sobre a Vida Religiosa Negra e Indígena, do qual participavam membros de religiões não-católicas, com destaque para a metodista). O grupo católico já havia conseguido bolsas de estudo junto à Pontifícia Universidade Católica de São Paulo (PUC-SP), e a ideia de um pré-vestibular voltado prioritariamente para as populações "afrodescendentes" foi decisivamente fortalecida após a apresentação, no I Seminário Nacional dos Estudantes Universitários Negros (Senun), ocorrido em Salvador, no ano de 1993, de um curso para negros pelo Instituto Cultural Steve Biko, daquela cidade. A esses grupos, se juntaram outros militantes interessados na iniciativa pela confluência entre o corte racial e a questão educacional. (2003: pág 130).

De acordo com o autor, percebe-se a heterogeneidade de instituições e grupos que foram referências para PVNC. Essas referências tinham em comum a bandeira de luta pela igualdade racial, e essa questão serviu de motivação para congruência de grupos da base religiosa e grupos não religiosos.

No que tange ao primeiro núcleo do PVNC, Santos analisa como se deu a composição do corpo docente e da coordenação em uma primeira experiência, que contava com membros das instituições que se uniram para organização do PVNC.

(-) a equipe do primeiro núcleo contava com quatro coordenadores e dez professores. Dentre esses militantes não ligados a grupos religiosos, três se juntaram ao frei David Raimundo dos Santos para constituir a coordenação do primeiro núcleo: Alexandre Nascimento, Luciano de Santana e Antônio Dourado. (Santos: 2003, pág. 131).

Neste contexto, a diversidade da composição inicial significa que o PVNC teve diversas referências e influências, tanto do grupo ligado ao Católico quanto de militantes do Movimento Negro. Essas influências serviram de base para a organização do PVNC, sobretudo no que se refere às questões políticas e ideológicas que iriam nortear a ação do movimento de educação popular.

Segundo Nascimento (2012): 
Três experiências são fundamentais para entendermos a constituição do movimento dos cursos pré-vestibulares populares: o curso pré-vestibular da Associação dos Trabalhadores da Universidade Federal do Rio de Janeiro - Assufrj (atual Sindicato dos Trabalhadores em Educação da Universidade Federal do Rio de Janeiro - Sintufrj); o curso Mangueira Vestibulares, criado no Rio de Janeiro para atender aos estudantes do Morro da Mangueira; e o curso da Cooperativa Steve Biko, criado em Salvador. Essas experiências foram importantes referências para as pessoas que montaram o primeiro curso denominado de Pré-Vestibular para Negros e Carentes. (pág. 69).

O autor destaca as instituições ligadas ao Movimento Negro, ou seja, os grupos não religiosos que, para o autor, influenciaram e serviram de inspiração para criação do primeiro núcleo do PVNC. Todavia o autor destaca o curso Steve Biko como a principal referência na gênese do PVNC.

O Curso Pré-Vestibular da Cooperativa Steve Biko (atual Instituto Steve Biko) surgiu em 1992 para preparar estudantes negros para os exames vestibulares. O nome Steve Biko foi dado em homenagem ao líder sul-africano, morto pelo apartheid. Esse curso se apresenta como uma forma de combate ao racismo e como afirmação de identidade. Mesmo não sendo uma experiência que surgiu no Rio de Janeiro, o Curso de Cooperativa Educacional Steve Biko foi uma importante referência para o grupo que fundou o PVNC e, por ser a concretização de uma proposta surgida nos debates do movimento social negro, teve grande impacto no interior desse movimento social. (Nascimento: 2012; pág. 71).

Sendo assim, de acordo com os autores citados, percebeu-se que as principais referências e influências do PVNC são constituídas por representações de organizações da Igreja Católica e também de instituições ligados ao Movimento Negro. Neste sentido, os estudos e pesquisa de Renato Emerson dos Santos (2003), (2005) e Alexandre do Nascimento (2012), entre outros autores, apresentam produções teóricas acerca do PVNC, que são referências para o estudo desta temática.

Dito isto, o PVNC contava com a estrutura da Igreja Católica e isto facilitou a criação de novos núcleos nos espaços eclesiais, isto é, nas salas das paróquias. O grupo ligado à Igreja Católica era denominado Grupo Eclesial (Santos, 2003), este grupo foi o principal articulador do PVNC e responsável pela formação da maioria dos novos núcleos.

Segundo Renato Emerson (2003), o chamado formato eclesial foi o método escolhido pelo grupo liderado por Frei David no PVNC. Este formato se baseava na autogestão e articulação do trabalho em rede. Para o autor, ainda no início do 
movimento, isto é, no ano de 1994, o PVNC cresceu tanto nas suas atividades internas dos "Prés" quanto na ampliação externa com novas parcerias e rede de contatos,

nos espaços físicos cedidos pelas igrejas, para a formação de novos núcleos de prévestibulares. O "grupo eclesial" fez importantes articulações com outras organizações religiosas, o que possibilitou a ampliação dos núcleos e o fortalecimento de uma rede de contatos institucionais com capacidade de cessão de espaços. Ficou, assim, impressa "fortemente sua marca ao conjunto: dos seis núcleos que começaram a funcionar já no início de 1994, cinco utilizavam espaços de igrejas ou colégios religiosos, com apoio de lideranças eclesiais (...), o que ampliava o leque de organizações envolvidas". (Santos: p. 132).

Entretanto, o PVNC crescia e catalisava também diversos outros movimentos não religiosos que também tinham como bandeira comum a questão da inserção de negros e pobres no ensino superior. Esse potencial de agregação e multiplicação colocou o PVNC no cenário político social como um dos mais importantes movimentos de educação popular da década de 1990. Contudo destacamos que essa característica é fundamental para a reflexão da atuação do PVNC enquanto movimento social.

Neste sentido, a questão do negro nas universidades era uma pauta antiga do movimento negro, mas essa reinvindicação adquiriu um fôlego novo e maior visibilidade na década de 1990, a partir da organização do PVNC de outros movimentos que se uniram em torno dessa bandeira comum.

O PVNC e outros movimentos sociais passaram a atuar também nos espaços políticos de discussão, pois o momento de reabertura política propiciou um solo fértil para participação dos movimentos sociais nas arenas de discussão e reinvindicações.

Segunda Ângela Paiva:

Essa é uma história longa e cheia de meandros, e certamente estão sendo trazidas aqui apenas algumas das circunstâncias mais importantes que expliquem essa confluência entre atores, ação governamental e a produção de mudanças estruturais na esfera pública. E como terceiro e último ponto a ser destacado para essa confluência na década de 1990, vale lembrar a criação de inúmeros vestibulares comunitários, que trazem uma nova alternativa para que "negros e carentes" possam se preparar para o vestibular. Se antes essa preparação era restrita às classes média e rica pelo alto custo, os prévestibulares comunitários vão trazer novos candidatos para o vestibular. Com as políticas de cotas, esse acesso passa a ser uma realidade efetiva. Como resultado concreto, há uma parcela expressiva de jovens moradores da periferia ou de favelas que passam a estar em condições mínimas de igualdade de chegar ao vestibular. (2010, pág. 32). 
A autora contextualiza o cenário político do país na década de 1990 e destaca o surgimento de pré-vestibulares comunitários - PVCs no contexto da época. Para Paiva, os PVCs tiveram uma importante atuação no campo da educação superior, pois essa atuação alterou a configuração das universidades no tocante à presença de negros e pobres nos bancos das universidades.

Não obstante isso, a importância da atuação do PVNC não se dá apenas no campo pedagógico da educação, mas também no campo das disputas políticas, pois o contexto de reabertura para participação social criou novas possibilidades de intervenção na esfera pública. Neste contexto, a inserção de negros e pobres nas universidades brasileiras passa a ser pauta na agenda política e a luta do PVNC ganha em visibilidade e adesão de outros movimentos.

Os movimentos sociais percebem que o período de reabertura política do país é oportuno para colocarem na pauta da sociedade brasileira suas bandeiras históricas de lutas e também novas demandas que se apresentavam como reinvindicações legítimas, pois o momento de efervescência e de redemocratização do país propicia a criação de novos espaços de debates, tais como, fóruns, conselhos de direitos, conferências, etc., possibilitando a mobilização e articulação desses movimentos para criação de uma agenda ampla de reivindicações.

Segundo Paoli e Telles,

(...) Os movimentos sociais se ampliaram e diversificaram, trazendo para o debate público um amplo leque de temas e questões que traduzem uma litigiosidade sempre renovada, recobrindo as mais diversas dimensões da vida social: questões relativas às discriminações de gênero, raça e etnia, ecologia e meio ambiente, violência e direitos humanos, passando a compor, no decorrer da década, uma agenda pública de debates, projetando na esfera política concepções ampliadas de direitos de cidadania que incorporam as exigências de equidade e justiça nas dimensões societárias e culturais, que afetam identidades, existências e formas de vida. Como mostra Sônia Alvarez, em torno desses movimentos articulou-se uma trama associativa ampla, multifacetada e descentrada, articulando associação de base, grupos de assessoria, ONGs, igrejas, profissionais liberais, sindicatos e mesmo universidades. Nessa trama feita de arenas públicas plurais e heterogêneas, se produz, enfatiza Alvarez, algo como capilaridade dos novos temas e exigências éticas de cidadania, que atravessa diversos grupos sociais, instituições, organizações e partidos e que se traduz em capacidade, por vezes inusitada, de articulação e mobilização de atores coletivos. (Paoli e Telles in Alvarez, Dagnino e Ecobar: 2000; pág. 106).

Dito isto, compreendemos que os chamados "direitos de cidadania" passaram a compor essa agenda de reinvindicações dessas instituições, organizações, grupos, enfim, 
dos movimentos sociais. Entretanto chama a atenção na narrativa dos autores o fato de sublinharem alguns temas que passam a ser constantes na pauta desses movimentos, isto é, as questões de gênero, etnia, raça, meio ambiente, etc. Contudo é importante destacar que os movimentos que pautam o debate em torno dessas demandas ficaram conhecidos como os "novos movimentos sociais".

Identificamos que o PVNC - enquanto movimento social - é parte integrante dos "novos movimentos sociais". Enfim, essa conceituação é utilizada por alguns autores para identificar alguns movimentos sociais que se destacaram na sociedade brasileira no Pós-Constituição de 1988 e que foram de grande importância.

\section{2 \\ Pré-Vestibular para Negros e Carentes e os Movimentos Sociais}

O debate em torno dos movimentos sociais não é uma novidade, pois não é de hoje que a história nos mostra as lutas, embates e disputa entre classes com participação efetiva dos movimentos sociais. No entanto, de acordo com o momento histórico, social e político de cada época, percebemos transformações e mudanças no que se refere à organização e atuação dos movimentos sociais. Neste contexto, sobre o recorte histórico da nossa pesquisa, Gohn contextualiza:

(...) a partir da década de 1990, ocorreu o surgimento de outras formas de organização popular, mais institucionalizadas, como a constituição de Fóruns Nacionais de Luta pela Moradia, pela Reforma Agrária, Fórum Nacional de Participação Popular etc. (...). Emergiam várias iniciativas de parcerias entre a sociedade civil organizada e o poder público, impulsionadas por políticas estatais, como a experiência do Orçamento Participativo, a política de Renda Mínima, bolsa-escola etc. A criação de uma Central dos Movimentos Populares foi outro fato marcante dos anos 90 no plano organizativo. Ela estruturou vários movimentos populares em nível nacional (...). Ética na política foi um movimento ocorrido no início dos anos 90 e teve uma grande importância histórica, porque contribuiu, decisivamente, para a deposição, via processo democrático, de um Presidente da República (...). À medida que as políticas neoliberais avançaram, foram surgidos outros movimentos sociais, contra as reformas estatais (...). Algumas dessas ações coletivas surgiram como resposta à crise socioeconômica, atuando mais como grupos de pressão do que como movimentos sociais estruturados. Os atos e manifestações pela paz, contra a violência urbana, também são exemplos dessa categoria. (Gohn: 2003). 
Outros movimentos também tiveram destaque no Pós-CF 1988, como a luta dos homossexuais, movimentos de defesa da ecologia e do meio ambiente, das mulheres, etc. O movimento pela igualdade racial também ganhou força na década de 1990, sobretudo o movimento de educação popular Pré-Vestibular para Negros e CarentesPVNC e outros similares que surgiram a partir dessa vertente.

A literatura que discorre sobre os movimentos sociais é ampla e vários são os conceitos que definem o que são "movimentos sociais". Nesta perspectiva, dentre os teóricos que se dedicam a esse debate, optamos pela definição de Maria da Glória Gohn.

Ações sociopolíticas construídas por atores sociais coletivos pertencentes a diferentes classes e camadas sociais, articuladas em certos cenários da conjuntura socioeconômica e de um país, criando um campo político de força social na sociedade civil. As ações desenvolvem um processo social político e cultural, que cria uma identidade coletiva para o movimento, a partir dos interesses em comum. Esta identidade é amalgamada pela força do princípio da solidariedade e constituída a partir da fase referencial de valores culturais e políticos compartilhados pelo grupo, em espaços coletivos não institucionalizados. Os movimentos em geral, uma série de inovações nas esferas públicas (estatal e não estatal) e privadas; participam direta ou indiretamente da luta política de um país e contribuem para o desenvolvimento e a transformação da sociedade civil e política. (Gohn: 1997).

Este contexto corrobora com nossa compreensão de que o PVNC não é apenas um curso preparatório para o exame do vestibular, pois essa definição não alcança a amplitude deste movimento. Entretanto Nascimento define o PVNC como "movimento de movimentos", ou seja, são vários movimentos dentro do mesmo movimento.

E, ademais, alguns movimentos sociais que tiveram maior visibilidade no período de redemocratização do Brasil são identificados por alguns autores como os “novos movimentos sociais". Contudo, nesse estudo, o PVNC como Movimento Social de Educação Popular merece especial atenção.

a) Pré-Vestibular para Negros e Carentes enquanto Movimento Social de Educação Popular.

O PVNC é um movimento social de educação popular e sua atuação não se limita na preparação dos seus alunos para o exame do vestibular, mas há também a preocupação em trabalhar a formação dos alunos em outros aspectos, como a 
participação nos espaços sociais e políticos, ou seja, a formação para o exercício da cidadania.

A atuação de lideranças do PVNC nesses espaços, desde sua fundação, foi fundamental para colocar na pauta da sociedade brasileira o debate da desigualdade racial nas universidades brasileiras. A participação nos fóruns, assembleias, congressos e arenas de discussão serviu como instrumento de pressão e questionamento do sistema educacional brasileiro e ao mesmo tempo servia para os alunos como aulas práticas de cidadania.

Segundo Santos:

Os pré-vestibulares populares são, desde os anos 1990, um dos mais importantes movimentos de tensionamento do sistema educacional do Brasil. Aparentemente concebidos/percebidos como uma crítica à elitização da universidade, eles foram difundidos por todo país pela atuação de entidades e militantes do Movimento Negro, que naquela década trouxeram à tona o debate sobre as desigualdades raciais na sociedade brasileira, tendo então a Educação como esfera central de expressão e reprodução. O núcleo organizacional que iniciou a difusão deste movimento foi o PréVestibular para Negros e Carentes (PVNC), criado na Baixada Fluminense por militantes da luta antirracismo, cuja atuação articulava a discussão racial nos campos religiosos, partidário e educacional. (Santos in Carvalho: 2008, pág. 188).

O autor contextualiza como o PVNC se consolidou como um movimento de luta pela igualdade racial no campo da educação, no ensino superior brasileiro, a partir da década de 1990. Essa questão é uma pauta antiga do movimento negro, mas que o PVNC assume como uma de suas bandeiras principais de luta. Entretanto é importante ratificar que a composição heterogênea, ou seja, a inserção de militantes do movimento negro no PVNC é um fator que potencializou o movimento nesse debate.

Neste contexto, também vale ressaltar a organicidade da Igreja Católica e a atuação no meio universitário como um fator que corroborou para que o PVNC se tornasse uma das principais referências da luta pela igualdade racial e social no ensino superior do Brasil. Contudo esses fatores deram visibilidade ao trabalho do PVNC e colocou-o como um dos mais importantes movimentos sociais urbanos da década de 1990.

No tocante ao período de transição democrática do Brasil, alguns movimentos sociais, entre eles o PVNC, ocuparam os espaços de participação política e apresentaram novas demandas, que passaram a fazer parte da agenda social brasileira. 
Neste sentido, a atuação desses movimentos fizeram alguns autores identificá-los como "novos movimentos sociais", conforme destaca Andréia Clapp.

Segundo Andréia Clapp:

Os movimentos sociais passaram a ser chamados de "novos movimentos sociais", tendo em vista as formas originais de se organizar, articular e manifestarem-se. Essas novas configurações nasceram e se entrecruzaram de forma dinâmica, especificamente ao longo das três décadas do século XX, mas foi principalmente na década de 1980 que houve uma efervescência dos novos movimentos sociais no Brasil, principalmente no período de transição democrática. (2008: pág. 128).

A autora destaca o período de efervescência no que diz respeito à conjuntura política e social, além de que esse fator favoreceu o surgimento dos "novos movimentos sociais". Esse destaque é fundamental para a compreensão da atuação desses movimentos, que passaram a ser identificados como "novos" por apresentar novas formas de organização e por acrescentar novas reinvindicações às demandas históricas. Nesta perspectiva, constroem uma agenda em que questões ligadas à identidade, gênero, raça, orientação sexual, entre outras, passam a fazer parte da pauta dos movimentos sociais de maneira mais acentuada a partir do Pós-Constituição de 1988.

Os "novos movimentos sociais", durante as décadas de 1980 e 1990, trouxeram para o cenário político brasileiro novos atores, antigas demandas e questões inéditas, que alteraram especialmente a dinâmica política do país. Nesse novo contexto, começaram a se organizar grupos sociais com identidades definidas - por raça, sexo, etnia, entre outros -, que exigiam seus direitos culturais e coletivos. Era uma nova forma de pensar direito e cidadania. (Clapp: 2008; pág. 128).

No arcabouço dos chamados "novos movimentos sociais", destacamos o PVNC como um dos representantes deste segmento, tendo em vista o seu caráter e atuação. A Constituição de 1988 traz um conjunto de direitos sociais, tais como, educação, saúde, habitação, entre outros.

O PVNC tem como bandeira principal o direito à educação, sobretudo no que diz respeito à população negra, que tem historicamente os seus direitos sendo negados. A materialização destes direitos passa pela participação em espaços políticos para criação de uma agenda que coloque este tema em pauta. Neste contexto, percebemos que o PVNC - junto com outros movimentos sociais de recorte racial - cumpriu esse papel. 
Segundo Paiva:

A segunda, e consequência da mesma anterior, está no surgimento dos novos
movimentos sociais de diversas matizes, movimentos que traduzem tanto reivindicações
antigas, como reforma agrária, como demandas novas, como o movimento gay, que luta
pelo reconhecimento de sua autenticidade na esfera pública. Já o movimento negro
traduz esses dois tipos de reivindicações, para usar a conceituação de Fraser (2003),
tanto reconhecimento de sua identidade, quanto redistribuição de bens sociais,
especialmente aqueles que possam promover uma concepção de cidadania, como
mudanças nas políticas de acesso ao ensino superior, ao mercado de trabalho e acesso à
justiça. Os movimentos sociais trazem novas formas de interlocução no espaço público,
imprimindo maior diversidade na esfera pública, maior participação e novas demandas,
ao explicitarem o conflito (Touraine, 1994) que estava apenas latente na esfera pública.
E o estado brasileiro democrático tem um importante papel nessa animação da esfera
pública: o de mediador dos conflitos. (2010, pág. 28).

A autora destaca o movimento negro no contexto dos "novos movimentos sociais", com importante atuação naquele período. Nesta perspectiva, destacamos o PVNC, que ampliou a questão da educação como um direito universal e a questão reconhecimento do povo negro e o direito a ter acesso às universidades e por consequência acesso a bens e serviços, isto é, o reconhecimento de sua identidade de raça, que não era colocado em pauta com tanta ênfase anteriormente.

Conforme já mencionado, a Constituição Federal de 1988 é um marco histórico, e os avanços no tocante aos direitos sociais são inegáveis. Todavia é preciso que o marco regulatório seja acompanhado de políticas públicas para que direitos sejam materializados. Neste contexto, a atuação dos movimentos sociais e de outros setores da sociedade tem o papel de pressionar o Estado e a sociedade para que os direitos não fiquem somente na legislação.

O PVNC é um movimento social que cumpriu esse papel de reivindicar políticas que possibilitassem o acesso da população negra ao ensino superior, pois o direito universal à educação - subscrito na CF 1988 - não era suficiente para que esta parcela significativa da população alcançasse esse direito.

Segundo Nascimento,

Entretanto foi na primeira metade da década de 1990 que este tipo de organização para lutar por acesso ao ensino superior ganhou popularidade e formas que tornam possível caracterizá-los como um movimento social. Isso começou a acontecer, principalmente, a partir do surgimento dos cursos Pré-Vestibulares para Negros e Carentes (PVNC), na região metropolitana do Rio de Janeiro. Por isso, estamos considerando as experiências 
que foram referências para popularização da proposta de curso pré-vestibular popular na década de 1990. Além disso, a gênese da configuração atual do Movimento dos Cursos Pré-Vestibulares Populares está relacionada aos novos contextos político-econômicos e às novas formas das lutas sociais (os chamados novos movimentos sociais), que surgiram com força na década de 1980. (2012: pág. 69).

De acordo com o autor, o PVNC se destacou por sua atuação na área da educação popular e na luta pela inclusão dos negros no ensino superior, no Brasil. No entanto o PVNC também se preocupa com a formação cidadã e a politização dos seus alunos, pois sua opção pedagógica não se restringe à preparação para o exame do vestibular, mas em ampliar a visão de mundo desses alunos diante das questões impostas pela sociedade.

Neste sentido, o PVNC criou a disciplina de Cultura e Cidadania como recurso pedagógico para trabalhar a perspectiva crítica dos seus alunos e ao mesmo tempo a formação de novos quadros para o movimento, isto é, seu objetivo não se limita à inserção de negros e pobres nas universidades, mas na formação cidadã de sujeitos políticos. No dizer de Santos (2003), "O pré deveria, por conseguinte, preparar o aluno não apenas para o vestibular, mas, sobretudo, para uma vida de luta política pela emancipação e promoção social das populações às quais ele pertence”. (pág. 135). O PVNC formava o aluno para atuar no próprio PVNC e em outros espaços políticos e de lutas por direitos.

Segundo Santos:

Isto se torna patente na criação, ainda em 1994, da criação da disciplina de "Cultura e cidadania" e, sobretudo, na sua consolidação. Ela surge como decorrência das discussões implementadas pelos militantes, que tinham como projeto um pré de corte popular e viam o processo educativo como uma possibilidade de adoção dessa postura. "Cultura e cidadania" foi formulada como o elo de convergência entre a preparação para o vestibular, a conscientização política e a busca de uma proposta pedagógica adequada à realidade e aos interesses dos segmentos sociais envolvidos no PVNC. (2003; pág. 134).

A disciplina de Cultura e Cidadania tem um recorte político, pois teoricamente os conhecimentos desenvolvidos na disciplina não são uma exigência curricular para o exame do vestibular, mas sua importância se dá no sentido de contribuir para uma perspectiva cidadã, de uma forma mais ampla e também como ferramenta pedagógica de formação de novos quadros para continuidade do próprio PVNC. 
A trajetória do PVNC é bastante exitosa e teve um crescimento do número de núcleos em um curto espaço de tempo. Também inspirou a criação de outros cursos prévestibulares populares em diversos lugares e instituições. Muitos desses grupos não tinham a questão racial como bandeira de luta, mas o acesso da população empobrecida ao ensino superior era o que eles tinham em comum.

Segundo Nascimento:

O movimento de Cursos Pré-Vestibulares Populares configura-se como um movimento de movimentos, pois é constituído por múltiplos movimentos (cursos autônomos, redes de cursos que são projetos de ONGs, sindicatos, universidades, associações, igrejas etc.) e constituinte de formas não convencionais de fazer política e organizar a luta (não há uma instância centralizadora, uma direção ou coordenação geral, como nas formas de organização mais tradicionais). Mas podemos dizer, entretanto, que as práticas desse movimento de movimentos convergem para uma demanda comum: o acesso ao ensino superior. (2012; pág. 61).

A expressão criada pelo autor - "movimentos de movimentos" - expressa o que se tornou esse fenômeno social e político, pois a heterogeneidade de movimentos que o PVNC ajudou a agregar em torno de uma demanda comum é um fato que merece ser sublinhado. Dito isto, alguns grupos não se sentiram contemplados com a questão racial, por pautarem outras questões ligadas à identidade, classe e de recorte social, que transcendiam a questão do negro. Contudo é importante reconhecer o PVNC como precursor dos pré-vestibulares populares, que pode ter servido de inspiração para criação de inúmeros cursos pré-vestibulares comunitários ou populares.

\section{b) "Movimentos de movimentos" - outros grupos interligados ao PVNC.}

Alguns movimentos similares ao PVNC surgiram com o mesmo objetivo do PVNC, isto é, a questão da universalização do acesso ao ensino superior. Porém alguns desses grupos tinham algumas divergências ideológicas em relação ao PVNC. E essas questões também tiveram rebatimentos internamente na direção do PVNC, causando conflitos e divisões no movimento.

O PVNC tinha - na sua composição dos grupos que disputavam a direção ideológica do movimento - o campo Negro, ligado aos militantes do Movimento Negro e o campo Eclesial, ligado aos Frades Franciscanos da Igreja Católica, Santos (2003). A disputa pela direção hegemônica do movimento culminou na dissidência entre os dois 
campos e na criação de uma nova vertente de pré-vestibular popular, que foi o EDUCAFRO, Educação e Cidadania de Afrodescendentes.

\section{Segundo Clapp:}

Outra importante referência como organização de pré-vestibulares populares é a Educafro, Educação e Cidadania de Afrodescendentes e Carentes, nascida de uma dissidência do PVNC. Os conflitos internos do PVNC, provocados por divergências com relação à direção política e pedagógica que estava sendo tomada, chegou a provocar a divisão do grupo da direção. Com a crise instaurada, Frei David se afastou e organizou uma nova rede de curso de pré-vestibulares para negros e carentes. (2008; pág. 134).

Entretanto não é o objetivo desta pesquisa aprofundar as questões que causaram a ruptura do PVNC e a fundação da EDUCAFRO, mas identificar outras experiências que são relevantes para compreensão das questões específicas do campo da pesquisa. Nesta perspectiva, é importante destacar que essa dissidência não significou o fim do PVNC, mas sim a possibilidade de agregar novos militantes e a expansão de novos grupos que surgiram a partir dessa experiência.

O projeto inicial, baseado numa perspectiva da formação de um aluno-militante, vem sofrendo vários desgastes. Entretanto, isso não tem significado o término de uma proposta, mas a certeza de uma nova conjuntura, que, mesmo sofrendo alterações, ainda é capaz de aglutinar um grande número de alunos e lutar pela inclusão, nas universidades, de determinados grupos sociais que vivenciam situações de exploração, discriminação e dominação. A expansão dos pré-vestibulares populares e suas inúmeras propostas de ação não retiram o valor do trabalho dessas organizações, mas torna mais complexa a compreensão desses cursos. (Clapp: 2008: pág. 135).

A autora apresenta outra questão importante, que vale destacar, isto é, ao passo que ocorre a dissidência do PVNC, surgem outros grupos que também atuam na lógica da inclusão das "minorias" nas universidades e ao mesmo tempo o PVNC continua ampliando a sua ação. Neste sentido, mesmo com todas essas questões, pode-se dizer que o PVNC serviu de referência para muitos dos cursos pré-vestibulares populares e/ou comunitários que surgiram naquele período.

A dissidência de alguns grupos do PVNC e o surgimento de novos segmentos similares, que tinham uma suposta "negação da questão racial" (Santos: 2003), não anulavam o caráter social e político dos núcleos que se desvencilhavam do PVNC e 
nem das novas experiências que surgiram, pois passaram a agregar outras demandas, tais como de identidades regionais e culturais,

(...). O Pré-Rocinha é um exemplo de tal percurso. Ao sair do PVNC, em 1998, seus membros decidiram modificar seu nome para Pré-Vestibular Comunitário da Rocinha, numa alteração resultante da convergência de duas negações: de um lado, sujeitos que negavam a questão racial como motivação de ações, que estavam no pré até então, mas que consideravam sua denominação racista; de outro, sujeitos - a maioria da comunidade - que apontavam que o nome 'negro' afastava mais do que aglutinava naquela localidade, cuja maioria dos moradores eles afirmavam serem nordestinos que não se identificavam como e nem como negros. (Santos: 2003; pág. 150).

Entretanto se algumas questões políticas e ideológicas foram determinantes para essa dissidência do PVNC e apesar das contradições que possam ter ocorrido durante este processo, é importante destacar que todos esses grupos apresentam como demanda comum o acesso ao ensino superior das camadas mais populares da nossa sociedade. Contudo o termo "comunitário" - adotado pelo pré-vestibular da Rocinha - ou "popular" chama atenção, pois encontramos inúmeros grupos com a mesma nomenclatura em sua forma de identificação.

Os Cursos Pré-Vestibulares Comunitários - CPVCs ou Populares têm muito em comum com o PVNC, pois a luta pela universalização do acesso à educação superior é a questão principal de convergência entre esses movimentos.

Outra questão que merece destaque é que muitas dessas novas classes comunitárias também surgiram nas dependências da Igreja Católica. A organização e estrutura dessa instituição são fatores que favoreceram essa multiplicação de grupos. Portanto, vale ressaltar a importância da compreensão desse processo para esse estudo, pois o campo da pesquisa, o Pré-Vestibular Comunitário Pompeia Santo Agostinho também surgiu em uma paróquia da Igreja Católica.

\section{3 \\ Os Cursos Pré-Vestibulares Comunitários - CPVCs}

O movimento dos Cursos Pré-Vestibulares Comunitários - CPVCS é um movimento de educação popular, com base comunitária e essa particularidade é uma característica que define a maneira como esse movimento se organiza. A organização 
comunitária também é importante como suporte que os CPVCs precisam para manter o "pré" funcionando, pois há o envolvimento das pessoas da comunidade com o desenvolvimento do trabalho.

A gestão dos CPVCSs é realizada de maneira democrática e conta com a participação dos educadores comunitários na tomada de decisões e na troca dos saberes, pois diferentemente dos pré-vestibulares "privados", não há a perspectiva comercial, ou seja, os objetivos são alcançar resultados coletivos que contribuam para o desenvolvimento da comunidade.

Segundo Lucinda (2002):

(...) vemos que em termos globais a Educação Comunitária visa uma articulação de objetivos concernentes à busca de solução de problemas (coletivos) concretos; reforço do funcionamento democrático de participação e poder de cidadãos e cidadãs na gestão pública em geral e da sua própria situação, em particular; promoção da capacitação de grupos de população através da formação, organização e desenvolvimento de relações entre diferentes grupos sociais; ajuda na luta pela justiça social para minorias e grupos sociais desfavorecidos; contribui para a melhoria da qualidade e (re)distribuição de bens e serviços e para a melhoria da qualidade de vida. (pág. 5).

Os grupos sociais a que se refere a autora são formados por pessoas envolvidas na organização de projetos sociais locais e essas pessoas contribuem para a mudança pessoal e também da comunidade. A participação dos atores sociais locais, nestes projetos, coadunam com a forma de participação dos educadores populares dos CPVCs, conforme modelo de gestão destacado neste trabalho.

Neste contexto, outra questão que merece destaque é em relação à população atendida nestes projetos, no dizer de Lucinda (2002), minorias e grupos sociais desfavorecidos, isto é, majoritariamente a população que tem na educação a porta de entrada para outros direitos e para uma melhor qualidade de vida.

A ação dos CPVCs, destinada à população empobrecida, caracteriza-os como movimento social de educação popular e luta pela cidadania dos atores sociais envolvidos, isto é, alunos, professores, coordenadores, entre outras pessoas das comunidades onde estes projetos sociais são desenvolvidos.

Segundo Alexandre Nascimento: 
Nominamos essa mobilização de "Movimento dos Cursos Pré-Vestibulares Populares" por ser ele composto por um grande número de cursos pré-vestibulares destinados à preparação de estudantes oriundos de camadas populares e pertencentes a grupos sociais discriminados e marginalizados (pobres, negros, indígenas, nordestinos etc.). Com o termo "populares", objetivamos fazer referência às camadas sociais, a grupos específicos que, historicamente no Brasil, vivem sob condições de exploração, subordinação, discriminação, tradicionalmente marginalizados em suas expressões singulares e culturais, com direitos fundamentais negados por parte das instituições que existem para garantir direitos, aos dispositivos de bem estar, ao reconhecimento cultural e à participação política. Entretanto o vocábulo "populares" é também utilizado para fazer referência a alternativas e formas criativas de enfrentamento dos problemas, produzidas pelos pobres. (2002: pág. 20 e 21).

$\mathrm{O}$ autor descreve as principais características que tornaram os CPVCs um dos movimentos sociais mais importantes da história recente do nosso país, pois essa parcela significativa da população teria poucas chances de inserção nas universidades brasileiras, se não fosse a ação desses projetos de educação popular. Entretanto esses grupos sociais também são formados para participação política como estratégia para possível mudança desse quadro social de negação de direitos.

No que se refere à ação dos CPVCs, além da questão pedagógica, há também a preocupação com a formação da cidadania dos seus alunos, pois as ações não se limitam à questão do ensino e aprendizagem para a conquista de uma vaga nas universidades brasileiras. O objetivo é também prepará-los para enfrentar os obstáculos dentro e fora da universidade após ingressarem no ensino superior.

Segundo Santos:

Por meio dessas iniciativas, os cursos pré-universitários buscam não somente aprovar os alunos no vestibular, mas também prepará-los para as dificuldades que encontrarão ao ingressar na universidade: mudanças de abordagens didático-metodológicas ou dificuldades de permanência, etc., questões cuja solução passa não só pelo fortalecimento dos alunos, mas também pelo envolvimento em seu meio social. (2005; pág. 202).

A preparação a que se refere o autor é de grande importância para esses alunos e funciona como um suporte para vencer os obstáculos da vida universitária, pois o acesso à universidade é apenas a primeira etapa que esses alunos precisam passar para alcançarem a concretização dos seus projetos de vida. Neste contexto, outra questão no tocante à preparação que os CPVCs proporcionam é em relação à formação política dos atores sociais envolvidos nas classes comunitárias. 
Segundo Lucinda (2002):

Conforme esta referência, é possível que em diversos contextos os educadores comunitários assumam papéis muito diferenciados, de acordo com as vicissitudes do lugar, do campo, das instituições, da sua formação humana, do seu posicionamento político. A diversidade é uma das marcas do/a educador/a comunitário que, em geral, desenvolve uma atividade existencial em paralelo com a profissional; tem postura idealista; e, por fim, apresenta uma identidade própria, muito clara, sem grandes ambiguidades sociais. Sem muito esforço, é possível associar o esboço do perfil do/a educador/a comunitário/a àquele sugerido por Paulo Freire acerca do educador na e pela cidadania. (Pág. 8).

A autora destaca a diversidade de papéis que são assumidos nas classes comunitárias e essa ação resulta na formação integral de todos os atores envolvidos neste processo, isto é, os professores se transformam em educadores populares e os alunos que recebem uma formação mais ampla se transformam em cidadãos ativos na sociedade. Contudo esse conjunto de fatores faz dos CPVCs mais do que um curso preparatório para o exame do vestibular.

Neste contexto, o professor José Carmelo B. de Carvalho contextualiza os CPVCs como movimento social urbano de relevante importância para a sociedade brasileira.

Segundo Carvalho (2005),

Com efeito, o risco reducionista de delimitar os CPVCs a meros espaços pedagógicos necessita ser superado, pela compreensão de que eles se constituem como um dos mais expressivos movimentos sociais urbanos, que vem ganhando crescente presença junto à sociedade política brasileira. (pág. 24).

A definição de que os CPVCs se constituem como movimento social de educação popular e que sua atuação não se restringe à dimensão pedagógica, mas conforme já mencionado nesse estudo - vai além de atuar no âmbito da sala de aula. Contudo o autor ratifica que a dimensão política também é uma característica marcante desses cursos, pois sua ação frente às questões sociais provoca o debate em torno da desigualdade social nas universidades brasileiras.

A criação de inúmeros CPVCs pode ser considerara como um ato político, haja vista que a educação é um direito universal assinalado na CF 1988, que não é assegurado de fato. Esses cursos atuam em duas frentes principais, a primeira é a 
questão pedagógica de preparar os alunos das classes comunitárias para competirem com chances a uma vaga na universidade e a segunda é no sentido de pressionar o Estado brasileiro em face da aparente desigualdade do quadro das universidades brasileiras.

Não obstante isso, Santos (2005) destaca o objetivo dos CPVCs - Populares.

O entrelaçamento das críticas nas quais se baseava a criação dos pré-vestibulares populares produzia, então, um discurso que apontava o próprio fim como objetivo, através da melhoria do ensino público, compreendia não apenas como índices mais elevados de aprovação dos alunos das escolas públicas no vestibular, mas com a realização plena de uma educação que formasse cidadãos críticos da estrutura da sociedade, nela inseridos, educados para igualdade e para os desafios da produção de conhecimento na universidade. (Santos in Carvalho: 2005: pág. 189).

Conforme posto nesta referência, é possível perceber que o objetivo dos CPVCs perpassa por várias questões no tocante ao direito à educação, no sentido de uma formação integral ou plena, para usar as palavras do autor. Todavia a crítica se dá ao sistema de educação, que não contempla a diversidade da população brasileira e também não proporciona aos alunos uma formação com perspectiva crítica à sociedade.

Neste contexto, os CPVCs têm formado muitos alunos pobres de comunidades periféricas com o signo de cidadãos atuantes na sociedade, independente do vestibular, pois no âmbito do cenário da educação brasileira, o vestibular passa por uma lógica da exclusão dessa parcela significativa da população, por isso o caráter político dos CPVCs é sem dúvida uma questão de cidadania no sentido amplo da palavra.

E, ademais, algumas instituições, como sindicatos, ONGs, partidos políticos, instituições religiosas, entre outras organizações, passaram a organizar núcleos de CPVCs em suas dependências, aumentando significativamente o número de prévestibulares de educação popular. Neste contexto, vale ressaltar que a Igreja Católica é uma dessas instituições onde muitos núcleos foram formados e, desta forma, é importante destacar esses processos.

\subsection{1}

\section{Os Cursos Pré-Vestibulares Comunitários com base na Igreja Católica}


A Igreja Católica é uma instituição com um histórico na área social que merece ser destacado. E compreender a relação dos CPVCs com essa instituição histórica é importante para os objetivos deste estudo.

Dito isto, o período histórico que permite uma melhor compreensão da atuação desses movimentos é anterior ao da redemocratização do Brasil, ou seja, o período do regime militar. Todavia, neste período, a Igreja Católica no Brasil sofreu influências das decisões que a instituição tomou nos níveis continental e mundial. Neste período, destacamos alguns acontecimentos importantes, como o Concílio Vaticano II e as Conferências Latino-Americana de Medellin e Puebla, que deram a tônica da ação da Igreja Católica no que tange à dimensão social.

O Concílio Vaticano II é um marco no que diz respeito aos documentos da Igreja Católica, pois se destaca por dedicar grande parte do documento final à abordagem das questões sociais inerentes àquele momento. Sendo este documento em nível universal, teve rebatimentos na instituição como um todo, sobretudo as conferências episcopais da América Latina e do Caribe, denominada Conferência Episcopal Latina Americana CELAM. Andreia Clapp, citando Solange e Andrade (2006), afirma:

Na década de 1970 e 1980, a estrutura da Igreja Católica vai sofrer grandes alterações, principalmente a partir de novas orientações religiosas. Segundo Solange e Andrade (2006), as mudanças que a Igreja Católica começou a sofrer surgiram a partir da influência do Concílio Vaticano II (1662-1965) e das Conferências Episcopais de Medellin (1968) e Puebla (1979). (...). (Pág. 92).

As conferências latino-americanas de Medellin e Puebla trazem um aspecto de destaque, que vai designar a direção da Igreja no que tange às ações no campo social, isto é, a opção preferencial pelos pobres. Cabe ressaltar que a igreja do Brasil, que compõe o CELAM, teve participação atuante nestas conferências, com a presença de representantes conhecidos no Brasil por atuarem frente às questões sociais enfrentadas pelo Brasil naquele período, dentre os quais podemos citar: Dom Helder Câmara, Dom Luciano Mendes, Dom Paulo Evaristo Arns, entre outros.

Essas novas orientações da organização latino-americana serviram de referência para uma ação mais organizada e sistemática da Igreja no enfrentamento das mazelas sociais, como pobreza e suas consequências. É importante destacar que essas orientações rebatem as bases populares da Igreja, mas também os intelectuais, 
acadêmicos, coordenadores que eram responsáveis pela formação e direção dos grupos e movimentos vinculados à instituição.

Essa nova Igreja, que assumiu a "opção preferencial pelos pobres", começou a atingir pessoas e grupos vinculados a instituições e grupos católicos. Essa nova direção católica fortaleceu-se a partir de uma ação dirigida às classes populares, mas que também atingiu acadêmicos, políticos e ativistas que tinham uma formação de esquerda - uma perspectiva religiosa que influenciou a formação principalmente daqueles sujeitos que atuavam intensamente em organizações católicas ou vinculadas a essa organização, como é o caso dos implementadores. (Clapp: pág. 93).

A Igreja Católica no Brasil também acompanhou esta tendência, sobretudo os grupos ligados à Teologia da Libertação ${ }^{1}$. Todavia, dentre os grupos que seguiam essa tendência, destacamos as Comunidades Eclesiais de Base-CEB's, as Pastorais Sociais e os grupos ligados à juventude católica, que ficaram conhecidos devido à participação em ações políticas, sociais e ideológicas no Brasil. Neste sentido, é comum encontrar em produções acadêmicas de historiadores, filósofos, sociológicos, entre outros, que destacam a participação desses grupos em momentos importantes da história do país.

O Sociólogo José Murilo de Carvalho, em seu livro Cidadania no Brasil - O longo Caminho, dedica parte da sua obra em contextualizar a atuação dos grupos da Igreja católica em momentos históricos do país.

Segundo Carvalho,

Dentro da Igreja Católica, no espírito da teologia da libertação, surgiram as Comunidades Eclesiais de Base (CEBs). A Igreja começou a mudar as atitudes a partir da Segunda Conferência dos Bispos Latino-Americanos, de 1968, em Medellin. Em 1970, o próprio Papa denunciou a tortura no Brasil. A hierarquia católica moveu-se com firmeza na direção da defesa dos direitos humanos e da oposição ao regime militar. Seu órgão máximo de decisão era a Conferência Nacional dos Bispos do Brasil (CNBB). A reação do governo levou a prisões e mesmo a assassinatos de padres. Mas a Igreja como um todo era poderosa demais para ser intimidada, como foram os partidos políticos e os sindicatos. Ela se tornou um baluarte da luta contra ditadura.

As CEBs surgiram em torno de 1975. Antes de 1964, os setores militantes da Igreja atuavam nos sindicatos e no movimento estudantil por meio da Juventude Operária Católica (JOC) e das Juventudes Estudantil e Universitária Católicas (JEC e JUC).

1

Teologia da Libertação: A Teologia da Libertação nasceu na Igreja Católica como resposta à contradição existente na América Latina entre a pobreza extrema e a fé cristã de maioria de sua população. Para a T.d.L., esta situação de pobreza fere o espírito do Evangelho, ofendendo a Deus. "A Teologia da Libertação encontrou seu nascedouro na fé confrontada com a injustiça feita aos pobres" (BOFF, 2010, p. 14) 
Dentro do novo espírito de aproximar-se do povo, sobretudo dos pobres, a Igreja passou a trabalhar também com as populações marginalizadas das periferias urbanas. $\mathrm{O}$ trabalho religioso ligava-se diretamente às condições sociais desses grupos e era ao mesmo tempo um esforço de conscientização política. Alguns teóricos da teologia da libertação aproximaram-se abertamente do marxismo. As CEBs expandiram-se por todo país, abrangendo também as áreas rurais. Por volta de 1985, seu número estava em torno de 80 mil. (...). (2011: pág. 183).

Essa contextualização ratifica a importância da atuação das organizações da Igreja Católica no contexto do trabalho social, no período histórico mencionado. Entretanto a atuação nos campos sociais e políticos do país continuaram nos anos posteriores, pois na fase de reabertura política ou período de redemocratização do país também há registros importantes da ação desses grupos. Neste sentido, vale lembrar que no regime militar os direitos políticos foram cerceados e era restrito à participação em movimentos sociais. Portanto, o período seguinte foi de reorganização dos movimentos sociais e de construção de novas formas de exercer a cidadania.

Ângela Paiva também destaca as CEBs e as pastorais que surgiram deste movimento como importantes organizações da sociedade civil, que foram referência tanto no período do regime de exceção como na fase de redemocratização do país.

Segundo Paiva,

Fazendo um pequeno parêntese, cabe aqui lembrar como organizações importantes da sociedade civil lograram fornecer espaços públicos importantes para instâncias geradoras de identidade num momento em que a esfera pública ainda estava sob controle de governos militares. É o caso das várias organizações profissionais que foram lócus de resistência durante o fechamento político ou, ainda, das diversas pastorais que surgiram nas Comunidades Eclesiais de Base da Igreja Católica, que foram cruciais no momento de transição democrática. E esta pode ser uma das apostas no revival da sociedade civil (Costa, 2002): as novas possibilidades de organização no espaço público colocam em relevo a importância da sociedade civil para equação do dilema da desigualdade brasileira. (2010: pág. 29).

A autora acentua a importância da sociedade civil no período de transição, reorganização do espaço público e de possibilidades de colocar na agenda do país a questão das desigualdades sociais emergentes no país. Com isso, as CEBs e as pastorais da Igreja Católica tiveram importante participação nesse processo. Contudo, após a Constituição de 1988, a atuação desses grupos no campo da cidadania se dá na participação no "espaço público", conforme destacado pela autora. 
No que tange aos CPVCs, com destaque para o PVNC, a questão colocada em relevo foi a da desigualdade brasileira no campo do ensino superior. Contudo, a Constituição de 1988 , no artigo $205^{2}$, diz que a educação é um direito universal e dever do Estado, mas não garante mecanismos para que esse direito seja efetivado conforme prescrito na Carta Magma. Nesta perspectiva, os movimentos de educação popular colocam em evidência na sociedade brasileira esse dilema e passam a pressionar o Estado para criação de políticas públicas com objetivo de corrigir esse erro histórico.

Os CPVCs - Populares ocuparam o espaço público para questionar a sociedade e o Estado sobre a ausência de negros e pobres nas universidades e passaram a reivindicar políticas de inclusão direcionadas a esse público. Neste sentido, os movimentos sociais, sobretudo os de educação popular, juntamente com outros setores da sociedade, lutaram pelas políticas de ação afirmativas como mecanismo de acesso ao ensino superior. Entretanto o processo de implementação dessas políticas não se deu naturalmente como um benefício concedido pelo Estado. A participação dos movimentos de educação popular no espaço público contribuiu para que essa questão entrasse na agenda política do país.

\section{4 Políticas de Ação Afirmativas Como Mecanismo de Inclusão dos Cursos Pré-Vestibulares Comunitários - Populares}

As Políticas de Ação Afirmativa são políticas sociais destinadas a grupos menos favorecidos e historicamente discriminados e/ou minorias, por exemplo: mulheres, negros, indígenas, homossexuais, pessoas com deficiência, etc. Contudo, no Brasil, o debate sobre a legitimidade dessas políticas vem sendo permeado de muita polêmica, passando a fazer parte da pauta de reinvindicações dos movimentos sociais junto à sociedade e ao Estado. A partir da promulgação da CF-1988, a pressão dos movimentos sociais ficou mais intensa e teve maior visibilidade na agenda política brasileira. Enfim, polêmicas à parte, o nosso objetivo neste capítulo é compreender como se deu o processo de legitimação das políticas de ação afirmativa no campo do ensino superior, no Brasil, e como foi a participação dos CPVCs nesse processo.

\footnotetext{
2 Art. 205. A educação, direito de todos e dever do Estado e da família, será promovida e incentivada com a colaboração da sociedade, visando ao pleno desenvolvimento da pessoa, seu preparo para o exercício da cidadania e sua qualificação para o trabalho.
} 
Como já mencionamos, as políticas de ação afirmativa são destinadas à população historicamente discriminada. Essa população é composta por grupos sociais que não conseguem acessar direitos ditos como universais. Entretanto, para que haja uma reparação histórica desse suposto "esquecimento", é necessário criar políticas sociais públicas e privadas com o objetivo de corrigir esse atraso histórico no campo do ensino superior.

\title{
Segundo Joaquim Barbosa:
}

\begin{abstract}
Atualmente, as ações afirmativas podem ser definidas como um conjunto de políticas públicas e privadas de caráter compulsório, facultativo ou voluntário, concebidas com vistas ao combate à discriminação racial, de gênero, por deficiência física e de origem nacional, bem como para corrigir ou mitigar os efeitos presentes da discriminação praticada no passado, tendo por objetivo a concretização do ideal de efetiva igualdade de acesso a bens fundamentais, como a educação e o emprego. Diferentemente das políticas governamentais antidiscriminatórias, baseadas em leis de conteúdo meramente proibitivo, que se singularizam por oferecerem às respectivas vítimas tão somente instrumentos jurídicos de caráter reparatório e de intervenção ex post facto, as ações afirmativas têm natureza multifacetária (RESKIN, 1997) e visam a evitar que a discriminação se verifique nas formas usualmente conhecidas - isto é, formalmente, por meio de normas de aplicação geral ou específica, ou por meio de mecanismos informais, difusos, estruturais, enraizados nas práticas culturais e no imaginário coletivo. Em síntese, trata-se de políticas e de mecanismos de inclusão concedidos por entidades públicas, privadas e por órgãos dotados de competência jurisdicional, com vistas à concretização de um objetivo constitucional universalmente reconhecido - o da efetiva igualdade de oportunidades a que todos os seres humanos têm direito. (2001: pág. 135).
\end{abstract}

De acordo com o autor, as políticas são consideradas um mecanismo de concretização de direitos sociais a grupos historicamente discriminados. Neste caso, trata-se de um mecanismo de inclusão de grupos marginalizados ou excluídos. Todavia Barbosa cita o termo utilizado no direito europeu - "discriminação positiva" ou "ação positiva" -, pois é necessário tratar de forma desigual os desiguais ou tratar de maneira diferenciada os que nunca foram tratados com igualdade.

Desta forma, para melhor compreensão desta matéria, destacamos a seguir alguns objetivos que Barbosa atribui às Ações Afirmativas:

- a concretização da igualdade de oportunidades de uma raça em relação à outra, do homem em relação à mulher;

- eliminar os "efeitos persistentes" (psicológicos, culturais e comportamentais) da discriminação do passado, que tendem a se perpetuar; 
- a criação das chamadas personalidades emblemáticas, isto é, possibilitar a constituição de mecanismos institucionais de criação de exemplos vivos de mobilidade social, exemplos vivos, representantes de minorias que alcançam posições de prestígio, que podem servir de motivação para futuras gerações.

Desta forma, sobre as personalidades emblemáticas, vale ressaltar aqui o destaque feito por Barbosa:

Por fim, as ações afirmativas cumpriram o objetivo de criar as chamadas personalidades emblemáticas. Noutras palavras, além das metas acima mencionadas, elas constituíram um mecanismo institucional de criação de exemplos vivos de mobilidade social ascendente. Vale dizer, os representantes de minorias que, por terem alcançado posições de prestígio e poder, serviram de exemplos a gerações mais jovens, que veriam em suas carreiras e realizações pessoais a sinalização de que não haveria chegado a sua vez, obstáculos intransponíveis à realização de seus sonhos e à concretização de seus projetos de vidas. Em suma, com essa conotação, as ações afirmativas atuariam como mecanismo de incentivo à educação e ao aprimoramento de jovens integrantes de grupos minoritários, que invariavelmente resistem ao bloqueio de seu potencial de inventividade, de criação e de motivação ao aprimoramento e crescimento individual, vítimas de sutilezas de um sistema jurídico, político, econômico e social, concebido para mantê-los em situação de excluídos. (Barbosa: 2011; pág. 137).

Compreendemos as chamadas "personalidades emblemáticas" como ponto central das políticas de ação afirmativas pelo fato de servir como incentivo às minorias, no sentido de que essas personalidades são exemplos concretos de que é possível alcançar os objetivos almejados e a realização do projeto de vida dessas pessoas.

No que tange aos objetivos destacados pelo autor, corroboramos em relação à implantação de certa "diversidade" e de uma maior "representatividade" de grupos minoritários nos mais diversos domínios de atividade pública ou privada. Esse objetivo busca eliminar as "barreiras artificiais e invisíveis" que emperram o avanço de negros e mulheres. Contudo as políticas de ação afirmativas também têm como finalidade atingir objetivos de natureza cultural, ou seja, a criação de políticas públicas voltadas para a implantação do pluralismo e da diversidade. Neste caso, em se tratando de um país como o Brasil, onde percebemos visivelmente esse pluralismo e uma enorme diversidade cultural, é discrepante a não diversidade e pluralidade no corpo discente e docente das universidades brasileiras.

A compreensão acerca das políticas de ação afirmativa pressupõe o entendimento dos sujeitos especificados, já que as ações afirmativas são dirigidas para 
os grupos que se identificam - como afirma Piovesan (1998) - por gênero, raça e etnia, idade, orientação sexual, etc., isto é, para o sujeito especificado.

(...) do abstrato, genérico, destituído de cor, sexo, raça, idade, classe social e outros critérios, emerge o sujeito de direito concreto, historicamente situado, com especificidades e particularidades. Daí apontar-se não mais ao indivíduo genérica e abstratamente considerado, mas ao indivíduo especificado, considerando-se categorizações relativas a gênero, idade, sexo, etnia, raça, etc. (1998, pág.130).

Desta forma, a autora contextualiza que não se pode tratar o indivíduo de forma genérica ou abstrata, mas é necessário observar as peculiaridades e particularidades de cada um, isto é, o que a autora chama de especificação do sujeito determinado. Neste sentido, a diferença passa a ser utilizada para a promoção de direitos e não mais para "aniquilação" dos mesmos.

Dito isto, compreendemos que a adoção das ações afirmativas como política pública no Brasil é um tema complexo, que está além da questão do acesso das camadas populares a bens e serviços, ou seja, essa medida traz luz a questões históricas inerentes à nossa sociedade, marcas herdadas desde o período colonial, que não foram superadas e que se mantêm enraizadas até os tempos atuais. Contudo, como as desigualdades sociais atingem diretamente o público alvo das ações afirmativas, o efeito dessas políticas tem o caráter de reparação histórica e/ou podem ser utilizadas para amenizar tais marcas e injustiças a esses grupos historicamente discriminados.

Neste sentido, a adoção das ações afirmativas como política social é fundamental e possui um caráter compensatório, pois o histórico de negação de direitos e desigualdades sociais atinge especificamente essa parte da população, a quem se destinam tais políticas, por isso, segundo Piovesan (2006), são consideradas um instrumento de inclusão social.

Nesse sentido, como poderoso instrumento de inclusão social, situam-se as ações afirmativas. Essas ações constituem medidas especiais e temporárias que, buscando remediar um passado discriminatório, objetivam acelerar o processo de igualdade, com o alcance da igualdade substantiva por partes de grupos vulneráveis, como as minorias étnicas e raciais, as mulheres, dentre outros grupos. (pág. 40).

Portanto, não se trata de uma igualdade relativa ou uma suposição de que todos são iguais, mas sim a igualdade substantiva que coloca os grupos vulneráveis na 
condição de cidadãos e, sendo assim, como portadores de direitos que sem as políticas de ação afirmativa não era possível de ser concretizado.

Contudo é importante ressaltar que a concepção das políticas de ação afirmativas no Brasil se deu também devido à participação de organizações da sociedade civil, dos órgãos de defesas de direitos humanos, os movimentos sociais, a comunidade acadêmica, etc., pois a matéria tem sido alvo de constantes embates no âmbito do legislativo e também do judiciário.

Segundo Moehlecke:

Historicamente, as políticas públicas brasileiras têm se caracterizado por adotar uma perspectiva social, com medidas redistributivas ou assistenciais contra a pobreza, baseadas em concepções de igualdade, sejam elas formuladas por políticos de direita ou esquerda (Munanga, 1996). Com a redemocratização do país, alguns movimentos sociais passaram a exigir uma postura mais ativa do Poder Público diante de questões como raça, gênero, etnia e adoções de medidas específicas para soluções, como ações afirmativas. (2002, pág. 203).

Essa postura mais ativa, a que se refere a autora, tem se traduzido em políticas públicas destinadas ao público das ações afirmativas, por exemplo, a reserva de vagas para pessoas com deficiência, cotas para mulheres no legislativo e cotas raciais para negros nas universidades, entre outras.

Contudo vale lembrar que os movimentos sociais fizeram a sua parte no processo de interlocução com os diversos setores da sociedade e com o Estado. Neste contexto, o Movimento Negro foi muito atuante nos diversos espaços de participação e proposição políticas voltadas à população negra.

O Movimento Negro tomou várias iniciativas e pressionou setores, até que as políticas afirmativas começaram a entrar nas agendas dos governos. Neste sentido, merece destaque sua atuação na Conferência Mundial contra a Discriminação, em 2001, em Durban, África do Sul. Após esse encontro, desencadearam-se ações, no sentido de pressionar o Governo Federal para que cumprisse os compromissos assumidos, visando promover a inclusão. A partir disso, a temática racial começou a se institucionalizar como um dos grandes desafios da sociedade brasileira neste início de século. (Santos in Carvalho, Filho e Costa: 2005, pág. 208 e 209).

Dito isto, uma importante conquista - que pode ser considerada como um dos resultados da atuação dos movimentos sociais - é no campo do ensino superior, pois as políticas de ação afirmativas para o acesso de negros e pobres às universidades 
brasileiras perpassam por esse processo de participação política, nesses espaços citados acima, na mobilização de outros setores da sociedade civil, na pressão junto ao Estado e no envolvimento da academia neste debate, entre outras ações articuladas pelos movimentos sociais.

Outro "ator" que merece destaque no campo da implementação das ações afirmativas é o PVNC, que desempenhou um papel importante para o reconhecimento e institucionalização da referida política.

\begin{abstract}
Esse processo de lutas, institucionalização de políticas de cotas para negros no Brasil tem um importante agente político: O Movimento dos Cursos Pré-Vestibulares Comunitários para Negros. Além de constituir a base concreta que, desde o início dos debates sobre as cotas para negros no final da década de 1990, serve de referência para os proponentes das políticas de cotas, os Cursos Pré-Vestibulares para Estudantes Negros e Negras atuam ativamente no debate, posicionando-se a favor da cota para negros e, mais do que isso, atuando politicamente, interna e externamente, através de aulas, textos, palestras, acordos e debates, audiências públicas, ações judiciais, manifestações e manifestos, em que fundamentam suas posições, defendem, propõem, chamam atenção do Estado e da Sociedade, denunciam e reivindicam direitos e políticas de ações afirmativas de acesso e permanência para estudantes de origem popular negros/as. (Nascimento: 2012, pág.04).
\end{abstract}

Entre várias iniciativas, destacamos um exemplo de implementação de ação afirmativa no campo do ensino superior, através da ação dos movimentos sociais, que foi o programa desenvolvido pela PUC-Rio, que desde 1994 passou a conceder bolsas integrais a alunos oriundos do PVNC e depois dos CPVCs. Esta parceria institucional contou com a interlocução direta de lideranças do PVNC.

Neste período, a PUC-Rio era considerada uma universidade formadora da elite carioca e tinha em seu corpo discente os filhos e filhas das famílias mais abastadas da sociedade carioca. Portanto, a entrada de alunos negros e pobres de áreas periféricas do Rio de Janeiro na PUC-Rio tem um impacto bastante significativo, por isso essa é uma experiência afirmativa exitosa, que nasce na década de 1990 e se mantém até os dias atuais.

A PUC-Rio vem implementando uma política de ação afirmativa desde 1994, com objetivo de favorecer o acesso de camadas populares aos cursos de graduação, prioritariamente estudantes afrodescendentes e economicamente desfavorecidos. $\mathrm{O}$ Programa nasceu de um convênio estabelecido entre a PUC e o Pré-Vestibular para Negros e Carentes (PVNC), um movimento social de educação popular voltado para a inserção de estudantes afrodescendentes e de grupos populares nas universidades. $\mathrm{O}$ aluno do PVNC, quando aprovado no vestibular da PUC-Rio, recebia uma bolsa de 
ação social, o que possibilita cursar a Universidade com uma bolsa de estudos integral. A bolsa de ação social surgiu com a finalidade de atender, especificamente, aos alunos do PVNC, embora abrangesse, mesmo que em menor escala. (Andreia Clapp: 2008, pág. 127).

Todavia é importante registrar que a primeira experiência concreta na concessão de bolsas de estudos para negros e carentes nasce na PUC-SP. Na ocasião, a universidade concedeu 200 bolsas de estudos a estudantes oriundos do movimento negro. Entretanto essa experiência não teve continuidade (Clapp: 2010, pág. 131), mas serviu de referência para o PVNC no Rio de Janeiro.

Ademais, no caso da PUC-Rio, a proposta não partiu por inciativa exclusiva da universidade, mas foi uma resposta concreta às reivindicações do movimento social.

A nova parceria que se estabeleceu entre a PUC-Rio e o PVNC demarcou, então, o início do processo de materialização dessa proposta afirmativa na PUC-Rio. Isto não significa que a ideia nasceu na ou da Universidade. Ela foi uma resposta aos anseios dos movimentos sociais populares - sobretudo daqueles mais conhecidos como "os novos movimentos sociais" -, mas especialmente aqueles vinculados à Igreja Católica, que pôde se materializar no espaço acadêmico. (Andreia Clapp: 2008, pág. 127).

Esta parceria estabelecida entre o PVNC e a PUC-Rio foi uma experiência inicial e merece ser destacada. Outras iniciativas afirmativas no campo do ensino superior também contaram com a participação dos movimentos sociais, especialmente na esfera pública estadual.

A primeira experiência de cotas raciais em universidades públicas no Brasil se deu na Universidade Estadual do Rio de Janeiro - UERJ e UENJ, em 2001, através de uma lei na Câmara dos Deputados do Estado do Rio de Janeiro - ALERJ.

Das primeiras medidas implementadas, podemos citar a política de cotas para estudantes de escolas públicas e para negros na Universidade do Estado do Rio de Janeiro (UERJ) e Universidade do Norte Fluminense (UENF), a primeira experiência de cotas do Ministério do Desenvolvimento Agrário, na gestão do então Ministro Raul Jungmann; e o Programa "Diversidade na Universidade", do Ministério da Educação, na gestão do Ministro Paulo Renato. Este último não tinha o apoio de boa parte da militância, pois era apresentado como uma Educação que resistiu à implementação de cotas. (Nascimento: 2012, pág. 153).

Nisto, ratificamos a importância das políticas de ação afirmativas, de modo especial as que foram criadas com o objetivo de promover o acesso de grupos 
específicos ao ensino superior. Todavia é importante ressaltar outras leis e regulamentações, tais como, o ProUni (Programa Universidade para Todos - 2005), que foi instituído por meio de medida provisória e que o Ministério da Educação - MEC passou a utilizar o ENEM (Exame Nacional do Ensino Médio) como instrumento de seleção de bolsista para o ProUni e também o Sisu (Sistema de Seleção Unificada), que é o sistema informatizado, gerenciado pelo MEC, pelo qual instituições públicas de educação superior oferecem vagas a candidatos participantes do ENEM". (site sisu.mec.gov.br).

Como já comentamos anteriormente, em outras palavras, o processo em que se deu a constituição de tais políticas foi de intensos embates e disputas, pois possibilitar o acesso de cidadãos das periferias do Brasil ao ensino superior é colocar em xeque o "status quo" das elites da sociedade brasileira. Contudo promover políticas públicas que materializam direitos historicamente negados a grupos específicos é garantir cidadania àqueles que nunca tiveram o "direito a ter direitos".

\begin{abstract}
A política de ação afirmativa para educação superior é uma questão em si mesma controvertida: impõe que sejam repensadas não apenas critérios de acesso ao ensino de terceiro grau, tornando-os mais diversificados, mas também, em uma perspectiva mais ampla, questiona o critério do mérito em uma sociedade cuja desigualdade social é uma marca de origem da própria nação. Não é uma discussão fácil: a questão do acesso à educação superior está diretamente ligada à formação das futuras elites do País; e as políticas de ação afirmativa, quaisquer que sejam, interferem exatamente na formação profissional desses quadros, alterando sua configuração futura. Talvez seja por essa razão que as cotas na universidade provoquem muito mais controvérsia do que as cotas para as mulheres nos partidos políticos, ou mesmo cota para negros nos postos de trabalho da administração pública. (Paiva: 2004: pág. 14).
\end{abstract}

As políticas de ações afirmativas no Brasil perpassam por outras questões emblemáticas, que precisam de uma análise mais aprofundada, por isso não é nosso objetivo esgotar esse debate aqui. Todavia essas políticas contestam a hegemonia das elites do país em diversos setores da sociedade, sobretudo no campo acadêmico, pois as políticas de ação afirmativa provocaram uma mudança no perfil do estudante universitário no Brasil.

Segundo Moehlecke:

A avaliação do rumo de políticas tão recentes no Brasil, como o das ações afirmativas, tem necessariamente um caráter temporário e limitações provenientes do contexto político, social e econômico. (2002: Pág. 209). 
Corroboramos com a autora que destaca a fragilidade das recentes políticas diante de uma conjuntura política instável. É importante considerar que - em momentos de crises econômicas - as políticas sociais sofrem rebatimento direto, por isso a existência dos CPVCs ainda é de grande importância no contexto brasileiro.

Essa é uma questão que merece atenção, pois o que realmente está em jogo é a manutenção de estruturas de prestígio e poder, isto é, determinados espaços, como a universidade, configuram-se como lugar de poucos privilegiados em detrimento de outros muitos que não "pertencem" a esse lugar de status quo.

Segundo Barbosa:

Com efeito, a discriminação, como um componente indissociável do relacionamento entre os seres humanos, reveste-se inegavelmente de uma roupagem competitiva. Afinal, discriminar nada mais é do que uma tentativa de se reduzirem as perspectivas de uns em benefício de outros. Quanto mais intensa a discriminação e mais poderosos os mecanismos inerciais que impedem o seu combate, mais ampla se mostra a clivagem entre discriminador e discriminado. Daí resulta, inevitavelmente, que aos esforços de uns em prol da concretização da igualdade se contraponham os interesses de outros na manutenção do status quo. (...). (2011: pág. 133).

As políticas de ação afirmativas, portanto, são mecanismos de inclusão, mas também são instrumentos que proporcionam oportunidades para os que não teriam chance de alcançar lugares ocupados historicamente por grupos privilegiados, isto é, espaços considerados de poder e prestígio.

Essa diversificação no campo universitário significa ocupar um lugar que historicamente pertenceu aos grupos da elite quase que exclusivamente. As políticas de ação afirmativas são avanços e conquistas que contaram também com a participação dos CPVCs - Populares.

Enfim, é importante ressaltar o trabalho das classes comunitárias, que tem resultados significativos em vários aspectos, ou seja, possibilitou a inserção de muitas pessoas no ensino superior. Entretanto os resultados também são significativos no âmbito do exercício da cidadania dos atores sociais que atuam nos CPVCs - Populares. Neste sentido, o objeto da pesquisa é o Curso Pré-Vestibular Comunitário Pompeia Santo Agostinho - CPVCPSA, que completou 15 anos de fundação em 2016. 


\section{3 Curso Pré-Vestibular Comunitário Pompeia Santo Agostinho -
CPVCPSA: O Locus da Pesquisa}

O Curso Pré-Vestibular Comunitário Pompeia Santo Agostinho - CPVPCSA foi fundado no ano de 2001, no seio da Igreja Católica, nas dependências da Paróquia Nossa Senhora do Rosário de Pompeia, que fica localizado no bairro de Ricardo de Albuquerque, na Zona Norte, subúrbio da cidade do Rio de Janeiro.

O CPVCSA é uma experiência local que completou 15 anos de funcionamento e - desde sua fundação - é dinamizado por uma equipe composta por coordenadores e professores voluntários, que ministram aulas das disciplinas curriculares e, a partir de 2009, passou a ter também a disciplina de Cultura e Cidadania.

Em relação aos 15 anos do CPVCPSA, pôde-se perceber a importância de alguns de seus principais atores, os coordenadores e professores, ambos voluntários. Neste contexto, os entrevistados são cinco professores voluntários que atuam na gênese do PVC.

\section{1 \\ Os Precursores do Curso Pré-Vestibular Comunitário Pompeia Santo Agostinho - O Perfil dos Entrevistados}

Considerou-se no presente estudo que os precursores seriam os (3) fundadores, Pe. Antônio, Heros Santos e Rafael Dias e (5) professores voluntários que participaram do período de constituição do PVC. Entretanto não foi possível realizar as entrevistas com os fundadores pelas seguintes razões: o falecimento do Pe. Antônio e os outros dois não quiseram participar por razões pessoais. Porém os cinco professores voluntários foram devidamente entrevistados e estes também são considerados protagonistas dessa história.

Nos gráficos abaixo, estão destacadas as principais características dos entrevistados, isto é, gênero, raça ou cor, bairro de moradia referente ao período que atuaram como voluntários no PVC, religião, idade e escolaridade atual. 
Gráfico 1 - Sexo

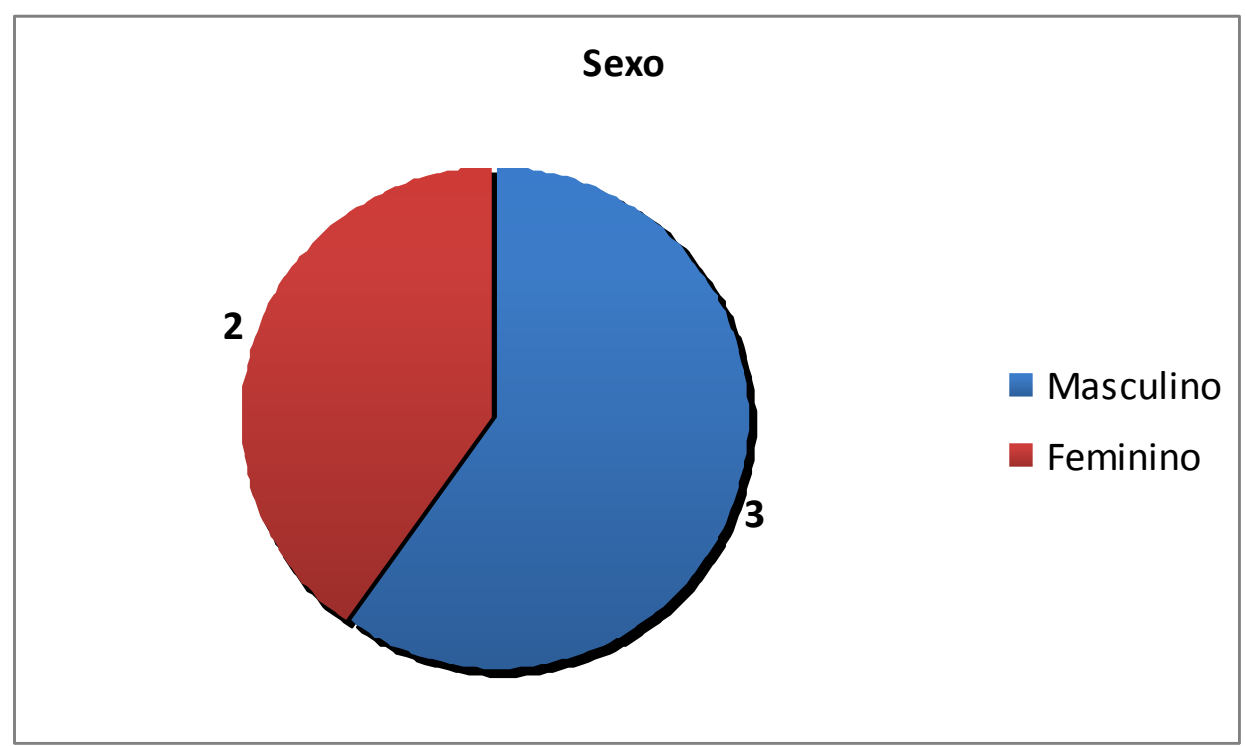

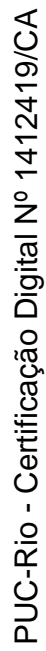

Gráfico 2 - Declaração de Cor

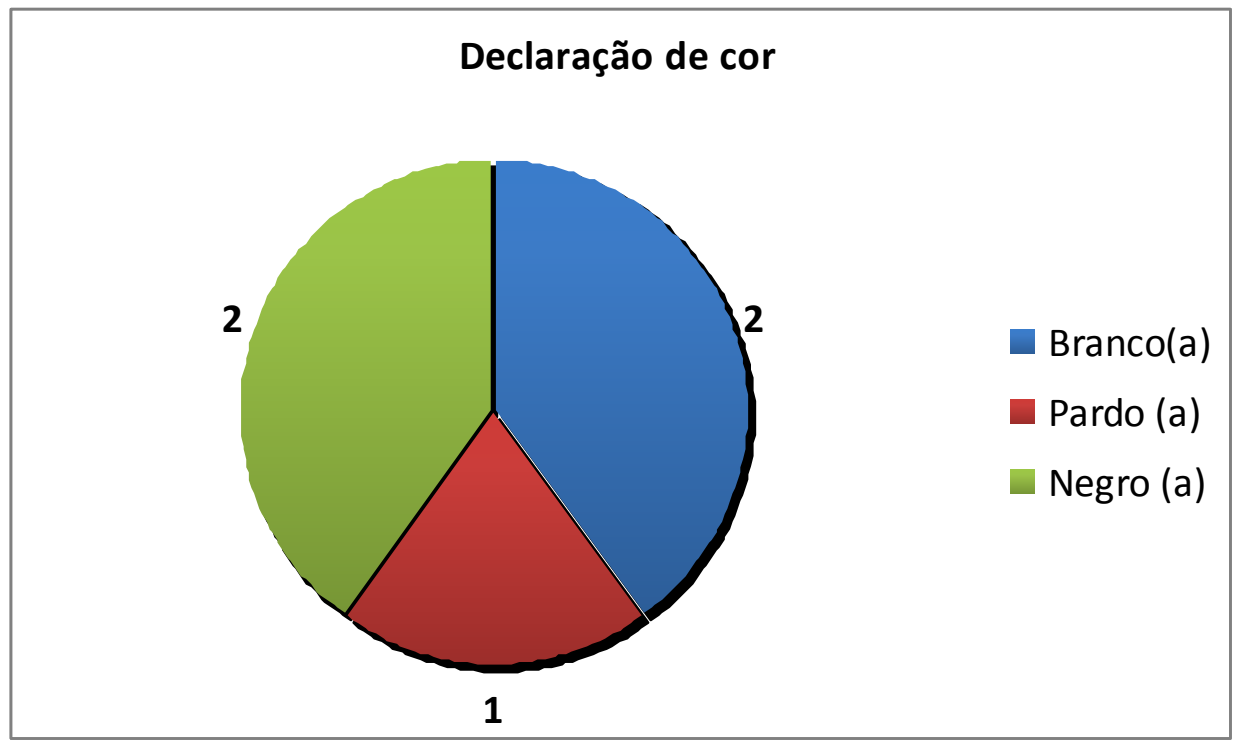

Os gráficos acima demonstram que os entrevistados são homens e mulheres, em sua maioria são negros (considerando negros e pardos), e brancos. 
Gráfico 3 - Local de moradia no período do Pré-Vestibular

\section{Bairro em que morava no período do Pré-Vestibular Comunitário}

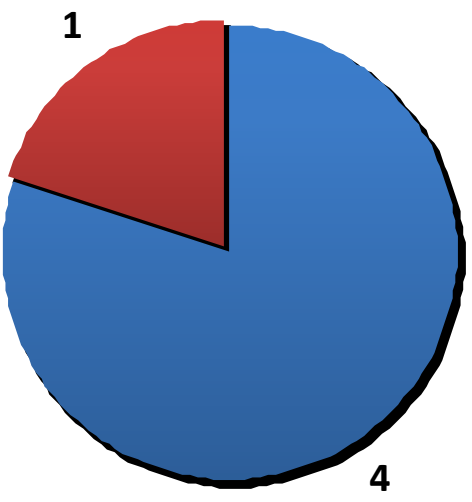

- Ricardo de Albuquerque

Parque Anchieta

No gráfico que identifica o local de moradia dos entrevistados, percebeu-se que estes são oriundos da região onde fica localizado o PVC, isto é, Ricardo de Albuquerque e Parque Anchieta, que são bairros vizinhos na Zona Norte do Rio de Janeiro.

Gráfico 4 - Religião

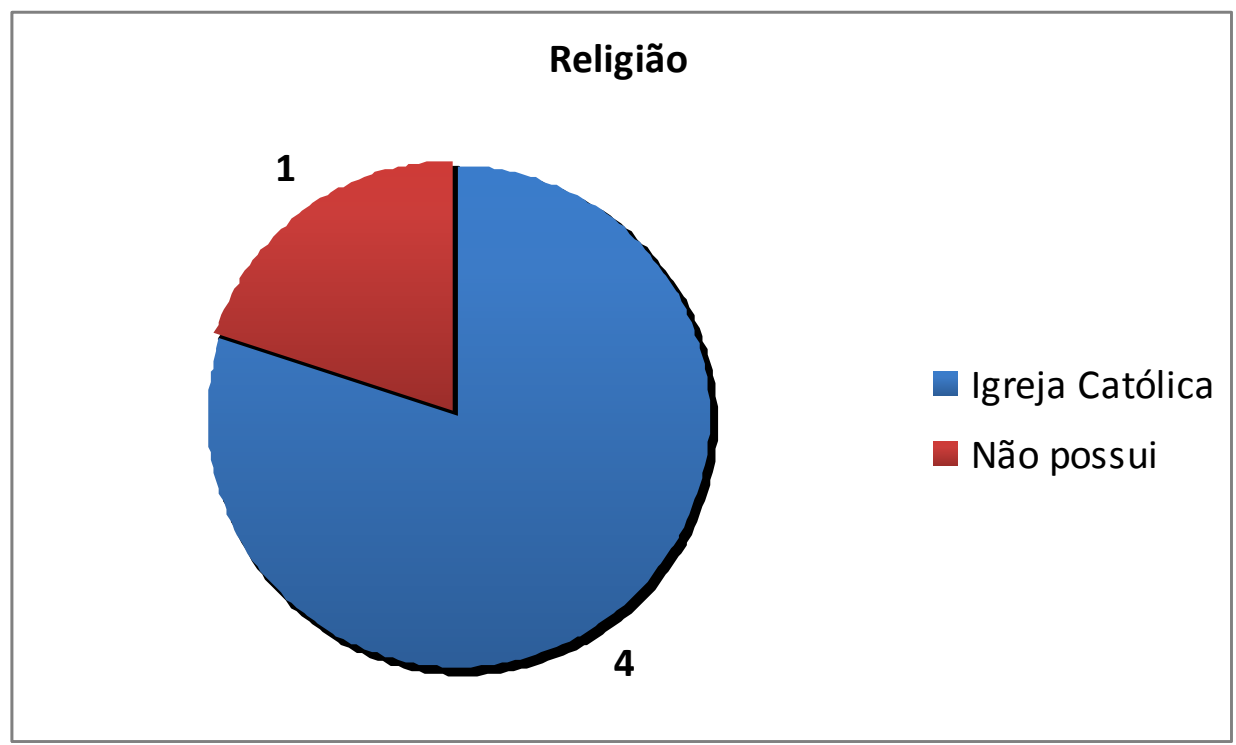


O dado 'religião' consta no roteiro de entrevistas pelo fato do pré-vestibular comunitário acontecer em um espaço religioso, isto é, nas dependências de uma Igreja Católica. Entretanto, apesar da maioria dos entrevistados se identificarem como católicos, este não influenciou a atuação dos professores voluntários no PVC, conforme veremos na análise dos resultados da pesquisa a seguir.

\section{Gráfico 5 - Idade no momento da Pesquisa (Janeiro 2016)}

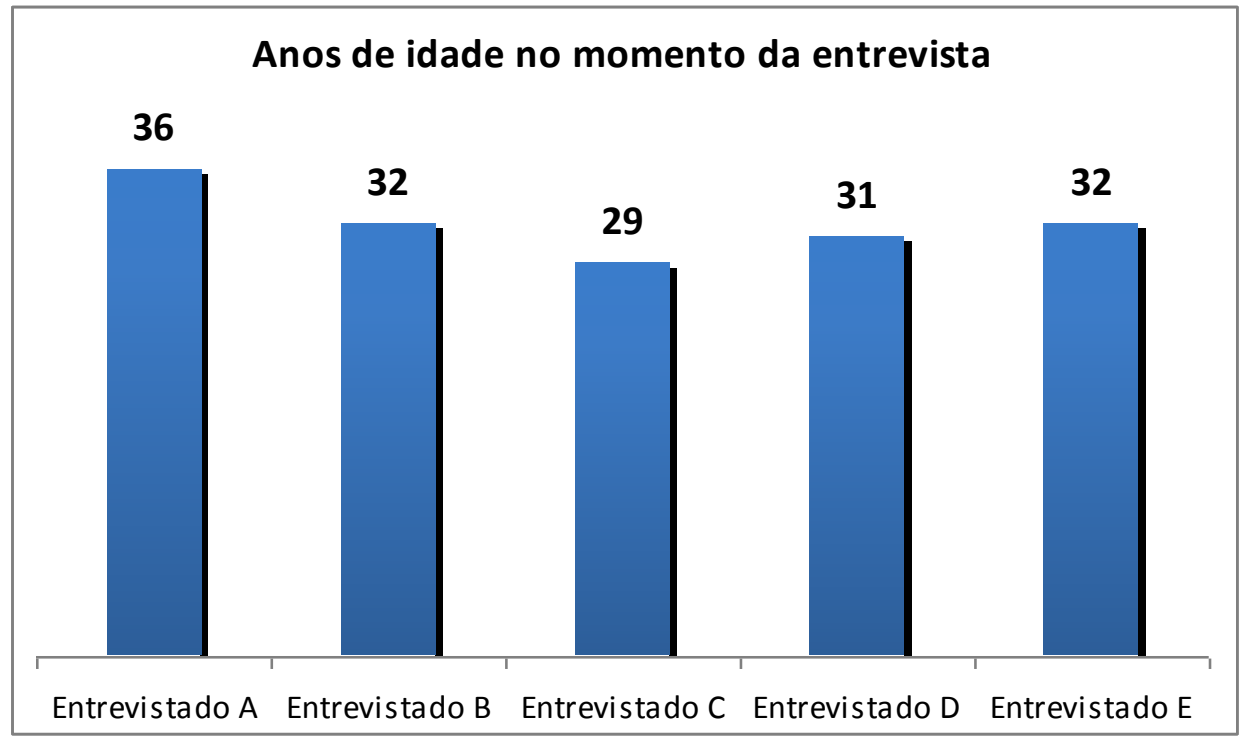

Quanto à idade, é importante destacar que este dado é referente à idade atual dos entrevistados e não a idade da época em que atuavam no PVC, mas como estes participaram da gênese do CPVCPSA (2001 a 2005), pode-se observar que eram bastante jovens quando ingressaram no PVC.

No momento de atuação dos entrevistados no PVC, identificou-se que todos já estavam cursando o $3^{\circ}$ grau.

Estava no quarto período de Faculdade de Letras. (Entrevistado A).

Primeiro período da Faculdade de Pedagogia. (Entrevistado B).

Estava terminando a Faculdade de Economia na Rural. (Entrevistado C). 
Quando eu ingressei aqui, eu tinha acabado de passar no vestibular, então basicamente era um graduando em física. Ok. Essa era minha posição na época. (Entrevistado D).

Estava no $1^{\mathrm{o}}$ ano da Universidade. (Entrevistado E).

\section{Gráfico 6 - Escolaridade Atual}

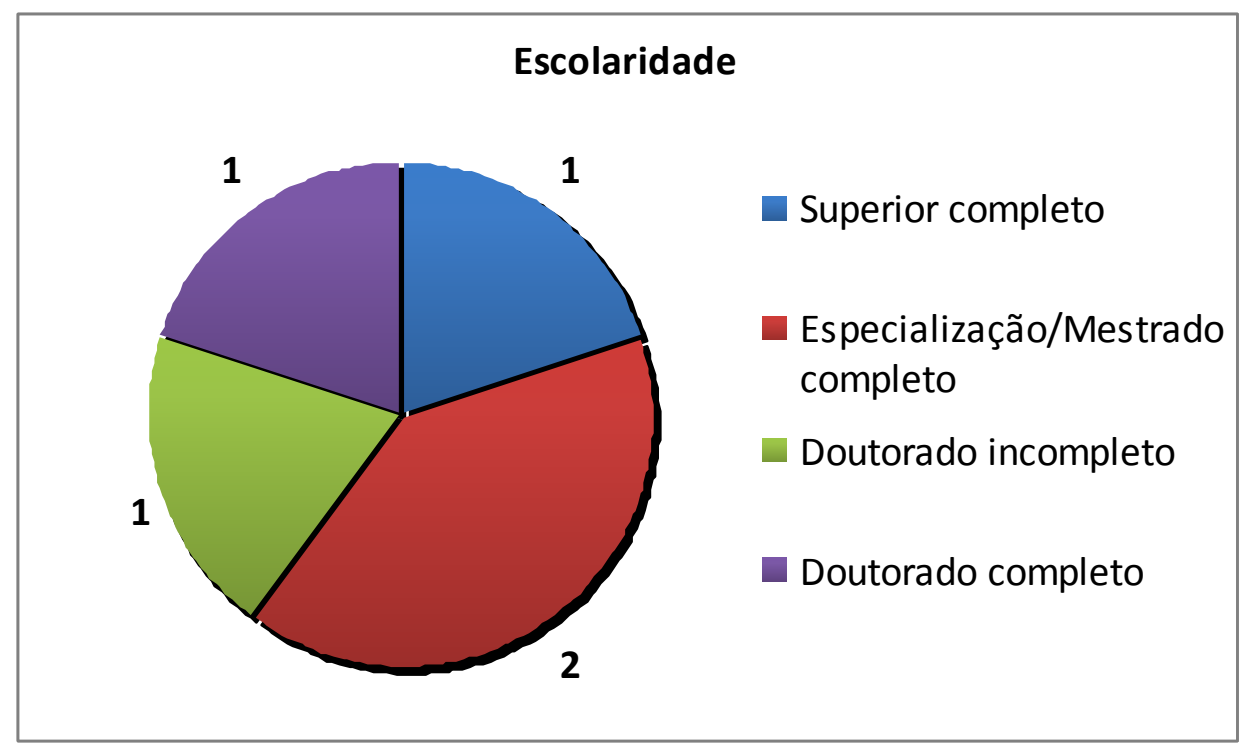

Merece especial destaque a atual inserção acadêmica dos professores voluntários que foram entrevistados na pesquisa. Hoje todos têm o curso superior completo e deram continuidade aos seus estudos, pois 1 tem o doutorado completo, 1 cursando o doutorado, 2 mestrado e especialização, o que demonstra o processo contínuo de formação profissional e a alta qualificação acadêmica.

A seguir, apresentaremos os resultados da pesquisa realizada com os protagonistas da história do Curso Pré-Vestibular Comunitário Pompeia Santo Agostinho. 


\title{
3.2 \\ A História do Curso Pré-Vestibular Comunitário Pompeia Santo Agostinho - A sua gênese e formação
}

\author{
"O que a memória ama, fica eterno". (Adélia \\ Prado).
}

O Curso Pré-Vestibular Comunitário Pompeia Santo Agostinho - CPVPCSA nasce no ano de 2001, nas dependências da Paróquia Nossa Senhora do Rosário de Pompeia, em Ricardo de Albuquerque. O início das atividades se deu a partir do trabalho de membros da paróquia, isto é, pessoas que tinham atuação pastoral e que desenvolviam ações no âmbito social da igreja.

Segundo as entrevistas, a gênese do CPVCPSA tem como fundadores três pessoas que eram atuantes na comunidade paroquial, entre elas o padre da paróquia na época.

\author{
Acho que foram Heros Santos, Rafael Dias e Pe. Antônio. (Entrevistado A). \\ Pe. Antônio, Heros e Rafael. (Entrevistado C).
}

Foi a Heros, até então pelo que eu soube, ela que foi a idealizadora e aí teve depois o professor Rafael, que na época era professor de literatura que ajudou e, de certa maneira, ajudou a botar o projeto para frente. A Heros com certeza foi a idealizadora. (Entrevistado B).

A minha mãe e o Rafael com certeza. (...) A Heros. Assim não há um fundador, mas o Padre Antônio era um incentivador total. (...) ele falava "jovem tem que está estudando, jovem tem que está na sala de aula, porque sem estudo" (...) Eu colocaria o nome dele como fundador. Entendeu? Porque pra mim foi a pessoa que mais incentivou para que as coisas acontecessem, né. É o Rafael Dias o Pe. Antônio e a Heros. (...). (Entrevistado E).

Essas pessoas são reconhecidas pelos entrevistados como os idealizadores do PVC, pois foram estes que organizaram o projeto, mobilizaram os voluntários, envolveram a comunidade e, enfim, deram início às atividades do CPVCPSA. Nas entrevistas, também foram identificados um segundo grupo de pessoas a serem considerados como protagonistas no início da formação do PVC, o grupo dos primeiros professores voluntários.

(...) quando eu cheguei, na verdade, o pré-vestibular já estava acontecendo, acho que já tinha um ano aproximadamente. As pessoas que participavam lá ativamente no prévestibular e continuaram ativamente após um longo período de tempo (...). Tem o 
suporte grande que era daqui da igreja, o pessoal da cantina, os zeladores, etc., que agora não vou conseguir me lembrar o nome de todo mundo. Assim que o ano virou e eu me tornei professor e alguns dos meus colegas que também tinham sido bem sucedidos no vestibular e se destacaram em alguma disciplina e acabaram virando professores também. Eu consigo citar o Fabio José e o Adelto Camilo. (Entrevistado D).

De acordo com o entrevistado acima, o pré-vestibular comunitário contava com a estrutura da igreja e o apoio dos primeiros professores voluntários, por isso constatase que estes foram personalidades importantes na gênese do CPVCPSA. Neste contexto, os entrevistados destacaram que a base do corpo docente era formada por ex-alunos que, após ingressarem nas universidades, retornaram para atuar como professores das disciplinas que não tinham professores. Sobre a constituição do corpo docente, o Entrevistado B afirmou:

(...) No decorrer do ano de 2002, alguns professores foram tendo que deixar o curso, principalmente por questões profissionais, outras, pessoais, então acabou que nós não ficamos com todos os professores até o final de ano de 2002, e aí, ou seja, quem é que dava aula para os alunos? Éramos nós alunos mesmos. (...) a nossa motivação já começou ali durante a preparação, pelo menos em 2002 nós tivemos essa questão, é nós, outros anos eu sei que com certeza foi melhorando porque aí nós mesmos nos sentimos numa obrigação de estar atuando, isso já no primeiro ano. Eu no primeiro período de UERJ já estava dando aula de história do Brasil, o Leandro passou para física, deu aula de física. (...) Eu fiz o Pré-vestibular em 2002, passei pra UERJ e comecei a dar aula em 2003. (Entrevistado B).

A fala do entrevistado mostra que a sua atuação como professor voluntário se deu a partir da própria inserção no curso universitário, quando - ao mesmo tempo em que o entrevistado dava aula no PVC - ele também fazia sua graduação. Um segundo aspecto, no que se refere à ação voluntária dos protagonistas, foi que a inserção se deu a partir do momento em que não havia professores para ministrar algumas disciplinas, o que exigiu uma imediata inserção dos estudantes como professores voluntários, conforme relatos abaixo:

Eu ingressei como aluno mesmo pra tentar o vestibular e depois regressei como professor a pedido da Heros, que estava precisando de professor de Geometria. Ela pediu para eu pegar a disciplina de Geometria no curso a partir de 2007. (...) E já se foram nove anos. (Entrevistado C).

(...) entrei no pré-vestibular da Pompeia para me preparar para o vestibular que eu quis prestar. (...) E, no ano seguinte, eu recebi um convite formal da coordenadora da época 
que era a Heros pra ser professor do pré-vestibular depois de eu ter sido aprovado no vestibular pra UFRJ. (Entrevistado D).

Desta forma, pode-se, então, constatar o importante trabalho de formação de agentes multiplicadores e a mobilização de novos voluntários a partir da percepção dessa necessidade real, isto é, a carência de professores voluntários de algumas disciplinas que são fundamentais no processo de preparação para o vestibular. Neste contexto, é importante destacar a prática do trabalho voluntário como um fator fundamental no desenvolvimento das ações do CPVCPSA.

Segundo Santos (2005),

(...) - o trabalho voluntário de professores e coordenadores - em um contexto marcado por desmobilização, esvaziamento da militância de diversos movimentos sociais no Brasil e, paradoxalmente, pela emergência de valores como solidariedade e participação, ainda que marcados por uma negação da dimensão política de sua participação. (...) Assim, os pré-vestibulares populares acabam por se constituir em um espaço público de socialização, um ator plural (ou ideologicamente plural), no qual se torna possível, através do múltiplo pertencimento, a recomposição de identidades coletivas em um cotidiano onde a democracia (essencialmente conflitiva) é radicalizada - as decisões são coletivas e os papéis são múltiplos e fundidos, alunos podem ser (e muitas vezes são) coordenadores e professores, etc. (2005: pág. 192 e 193).

O contexto em que o autor ressalta a importância do trabalho voluntário nos "prés" é bastante complexo, pois sua argumentação destaca a desmobilização e o esvaziamento da militância em alguns movimentos. Por outro lado, nos movimentos de educação popular, pode-se observar um crescimento da ação voluntária, sejam motivadas por uma questão de solidariedade ou pelo viés da participação política. Contudo, sem entrar no mérito do debate em relação à questão da militância política difundida nos pré-vestibulares populares, é importante ratificar o aspecto do voluntariado na consolidação da ação dos PVCs, conforme podemos observar no presente estudo.

Outra questão relevante, no que se refere ao processo de constituição do CPVCPSA, diz respeito sobre como era feita a divulgação do PVC no início das suas atividades.

Em um evento que eu estava na Pompeia, e aí a Heros (...) falou que já estava funcionando, ela até me perguntou se eu queria já começar a fazer (...) mas no outro ano em 2002 eu estava lá. (Entrevistado B). 
Eu sempre fiz parte aqui da comunidade. No primeiro ano que começou a iniciativa do projeto em 2001, na época tomei conhecimento, enfim conhecia algumas pessoas que estudavam no curso, eu via os movimentos aqui de $2^{\circ}$ a $6^{\circ}$ à noite e sábado pela manhã. Então sempre foi muito... Sempre tive muito conhecimento do que estava acontecendo no curso de pré-vestibular. (Entrevistado C).

Conversando com alguém, que estava se preparando para o vestibular, a pessoa sugeriu que eu viesse aqui na igreja que ela sabia que tinha um pré-vestibular comunitário e foi por isso que eu vim para cá. (Entrevistado D).

De acordo com os depoimentos acima, percebeu-se que a comunicação era no conhecido "boca a boca", pois era a maneira utilizada pelas comunidades para mobilizar e divulgar os projetos e ações locais, conforme constatado nas entrevistas.

Esta forma de comunicar é acrescida pelo sentimento de pertencimento desses professores voluntários à comunidade da Pompeia, conforme destacado nas entrevistas acima.

A história do CPVCPSA começa com a ação de agentes locais, pessoas que atuam em uma determinada Igreja (Nossa Senhora do Rosário de Pompeia), pertencentes à comunidade conhecida como Pompeia, e estas pessoas que iniciaram esse projeto mobilizaram outras pessoas da própria comunidade para serem os professores voluntários desse PVC, sobretudo ex-alunos recém ingressados no curso superior.

\section{3}

\section{As Motivações dos Protagonistas do Curso Pré-Vestibular Comunitário Pompeia Santo Agostinho}

Não tenho um caminho novo. O que eu tenho de novo é um jeito de caminhar. (Thiago de Melllo).

Segundo o dicionário da língua portuguesa, motivação é o ato de motivar e motivar é: 1. Expor os motivos, ou explicar as razões de. 2. Dar motivos a. 3. Despertar o interesse. 4. Incentivar.

As principais motivações identificadas nas entrevistas para os professores voluntários atuarem no CPVCPSA são: possibilitar a continuidade das atividades do "pré" e o sentimento de agradecimento com retribuição ao PVC e os laços criados de afetividade e identificação com a comunidade local. 
No tocante ao argumento destacado pelos entrevistados, em que havia a preocupação com a continuidade das atividades, se dava principalmente devido à carência de professores voluntários e o possível risco de ter interrompido o funcionamento do CPVCPSA. Neste contexto, alguns depoimentos merecem destaque.

(...) De querer ajudar, de manter este projeto, de dar continuidade a esse projeto. Teve um pouco essa questão também de querer fortalecer o projeto, que eu acho muito importante (...) E acho que a necessidade de dar continuidade desse projeto, que é um projeto importante para a comunidade, pra paróquia e para a sociedade como um todo. (Entrevistado C).

(...) E, neste mesmo ano que eu tive a comprovação que o pré-vestibular dava retorno para a comunidade, para os alunos dedicados, mas também percebi que havia uma dificuldade em encontrar professores voluntários para manter o projeto correndo, especificamente para minha disciplina que eu fiz, física. Então eu sabia da situação de física mesmo, porque no ano anterior quando eu estudei nós tivemos que fazer grupos de estudos por causa da falta de professores, então eu sabia dessas duas coisas, eu achei que eu podia contribuir nesse sentido, entendeu? Cobrir uma dessas duas partes que era proporcionar uma fonte alternativa de estudo para o pessoal, então voltaria como professor para manter o trabalho correndo que eu já tinha visto que funcionava. Acho que esse foi o principal motivo. (Entrevistado D).

Ao perceberem a importância da continuidade das atividades do PVC para atender à demanda de vestibulandos da comunidade da Pompeia, os entrevistados sentiram-se motivados pela ação voluntária como professor, porque eles tinham a compreensão de que a falta de professor para algumas disciplinas significava o sério risco de interrupção das atividades do CPVCPSA.

A preocupação com a continuidade do PVC é um dos motivos destacado por quase todos os entrevistados e perpassa por boa parte da pesquisa, pois os entrevistados fizeram questão de ressaltar a importância do PVC para a comunidade da Pompeia e por esse motivo - o CPVCPSA não poderia acabar.

Neste contexto, um dado que deve ser considerado como importante é o fato dos entrevistados terem sido alunos do CPVCPSA, pois a experiência pessoal contribuiu muito para que esses sujeitos regressassem ao PVC como professores voluntários.

Um segundo motivo destacado pelos entrevistados foi o sentimento de gratidão e retribuição pelo PVC.

Como eu mesma fui aluna alguns anos antes, e graças aos meus professores voluntários eu pude ingressar nos estudos superiores, então eu quis retribuir o bem que fizeram por mim. (Entrevistado A). 
(...) A primeira foi uma questão de gratidão em relação ao que eu consegui. (...) Mas teve a questão de retribuição, de querer voltar para retribuir aquilo que eu aprendi. (Entrevistado C).

(...) a motivação parte muito primeiro da sua experiência, ou seja, você ver os resultados. (...) então você percebe que é um trabalho que dá certo a partir do momento em que você, que cada um acredita no outro, na ajuda que outro pode dá, então eu acho assim, que a motivação ela surgiu mesmo da nossa experiência, da nossa motivação, da gente ter de nós mesmos acreditarmos em primeiro lugar e saber que esse crédito, essa força, ela poderia ser passado para outros. (Entrevistado B).

De acordo com os entrevistados acima, o sentimento de gratidão é destacado por quase todos os entrevistados. Esse sentimento de gratidão é o que move a vontade de retribuir ajudando outras pessoas que estavam na mesma situação em que se encontrava anteriormente. Portanto, o sentimento de gratidão somado ao desejo de retribuir o bem que receberam foram os principais motivos para os entrevistados assumirem o compromisso social com a comunidade da Pompeia e com o CPVCPSA em si.

E, ademais, essas duas principais motivações destacadas aqui foram importantes para o processo de constituição do CPVCPSA, pois foi formada uma base sólida, composta por pessoas comprometidas com o projeto e que desempenharam as funções de coordenadores e professores voluntários.

Outro aspecto destacado pelos entrevistados como motivação foram os laços afetivos criados entre professores voluntários, coordenação, com a comunidade da Pompeia e com a missão do CPVPSA, conforme os relatos abaixo:

(...) uma questão de convivência aqui na comunidade paroquial, aqui na Pompeia. (Entrevistado C).

(...) Então, eu acreditava no conceito de pré-vestibular comunitário que acontecia aqui na igreja da Pompeia. (...) Então, eu entendi que o grupo que existia aqui fazia a coisa funcionar, tá. Então, com tanto esses contratempos de pré-vestibulares comunitários, que é alta rotatividade tanto de alunos quanto de professores, eu sentia que mesmo assim o saldo era sempre positivo. O cara entrava aqui e saia com certa bagagem pra fazer o vestibular, então essa sensação que liderou a minha volta pra se tornar professor, e a outra coisa importante que aqui eu tinha, eu acabei criando um vínculo de amizade, cara. Então, tinha aquela sensação de segunda família aqui. Aí, então, era tudo próximo de todo mundo e isso facilitou bastante. Até aí são motivos secundários, mas também foi importante pra mim na época pra tomar essa decisão de vir pra cá, porque no final ninguém gosta de trabalhar num ambiente hostil. Então, principalmente você sendo voluntário, então, pelo fato do ambiente ser agradável facilitou enormemente a minha vinda para cá. (Entrevistado D). 
A criação de laços afetivos e o ambiente familiar do CPVCPSA funcionaram como motivação para os entrevistados e favoreceu a ação dos professores voluntários do PVC. Todavia as motivações destacadas acima levaram ao engajamento desses atores sociais ao PVC e ao compromisso com a resolução das demandas desse movimento, por exemplo, a carência de professores voluntários para determinadas disciplinas.

Os Pré-Vestibulares Comunitários trouxeram novos atores sociais para espaços de participação social e esses novos atores passam a ter contato com diversas questões inerentes à realidade das comunidades, o que faz do PVC um espaço de reflexão dos problemas das comunidades e de busca de soluções para atender às demandas que são apresentadas.

Não obstante isso, a partir da prática como educador comunitário, os professores voluntários não se limitam à questão do ensino e aprendizagem dos conteúdos pedagógicos curriculares exigidos pelo exame do vestibular, mas os educadores comunitários são envolvidos em diversas questões que transcendem o âmbito da sala de aula.

Segundo Lucinda:

O/a Educadora/a Comunitário seria o agente socioeducativo que se encontra, por um lado, num campo de tensão entre problemas concretos das pessoas e as soluções viáveis em curto prazo e, pelo outro lado, nos problemas em nível micro e na procura de soluções duráveis no âmbito de mudanças sociais mais amplas. Devido à sua especificidade, estas intervenções educativas deverão ser no âmbito local, abordadas numa perspectiva sistêmica e integrada, realizadas em moldes diversos da educação não-formal e educação popular. (2002: págs. 7 e 8).

Neste contexto, as motivações dos professores voluntários passam do estágio inicial, isto é, o objetivo primeiro - que é a inserção de alunos pobres nas universidades - e alcança a dimensão da educação popular como "Prática da Liberdade" aos moldes de Paulo Freire, ou seja, a educação comunitária como ferramenta de libertação dos mecanismos de discriminação e exclusão.

A inserção de professores voluntários no PVC com o objetivo de suprir as demandas imediatas, por exemplo, a carência de professores, foi apenas o começo da transformação desses agentes locais em sujeitos políticos atuantes na comunidade e na sociedade. O conceito de Educação Popular - amplamente difundido por Paulo Freire - é 
a base principal da maioria dos CPVCs - Populares. Este conceito foi sistematizado por Carlos Brandão (2006), que cita a crítica feita por Paulo Freire ao sistema vigente de educação.

A educação popular: 1) constitui passo a passo ("aos tropeços", dirão os seus críticos) uma nova teoria, não apenas de educação, mas das relações que, considerando-a a partir da cultura, estabelecem novas articulações entre a sua prática e um trabalho político progressivamente popular das trocas entre o homem e a sociedade, e de condições de transformação das estruturas opressoras desta pelo trabalho libertador daquele; 2) pretende fundar não apenas um novo método de trabalho "com o povo" através da educação, mas toda uma nova educação libertadora, através do trabalho do/com o povo sobre ela - este é o sentido em que a educação popular projeta transformar todo o sistema de educação, em todos os seus níveis, como uma educação popular; 3) define a educação como instrumento político de conscientização e politização, através da construção de um novo saber, ao invés de ser apenas um meio de transferência seletiva, a sujeitos e grupos populares, de um "saber dominante" de efeito "ajustador" à ordem vigente - este é o sentido em que ela se propõe como uma ampla ação cultural para a liberdade, a partir da prática pedagógica no momento de encontro entre educadoreseducandos e educandos-educadores; 4) afasta-se de ser tão somente uma atividade "de sala de aula", de "escolarização popular", e busca alternativas de realizar-se em todas as situações de práticas críticas e criativas entre agentes educadores "comprometidos" e sujeitos populares "organizados", ou em processo de organização de classe; 5) procura perder, aos poucos (o que nem sempre consegue), uma característica original de ser um movimento de educadores e militantes eruditos, destinado a "trabalhar com o povo", para ser um trabalho político sem projeto próprio e diretor de ações pedagógicas sobre o povo, mas a serviço dos seus projetos de classe. Este é o sentido em que há, hoje em dia, um consenso de que a missão do educador popular é participar do trabalho de produção e reprodução de um saber popular, aportando a ele, ao longo do trabalho social e/ou político de classe, a sua contribuição específica de educador: o seu saber erudito (o da ciência em que se profissionalizou, por exemplo) em função das necessidades e em adequação com as possibilidades de incorporação dele às práticas e à construção de um saber popular. (Brandão: 2006; págs. 46 e 47).

O autor chama atenção para a diferença da educação popular para a educação do sistema formal de ensino, pois a prática da educação popular leva em consideração a realidade e particularidades de cada lugar. A atuação no PVC como educador popular é um ato político e - para muitos professores - é o primeiro espaço de militância em um movimento social.

Os professores voluntários do CPVCPSA apresentaram algumas motivações que foram destacadas neste estudo, mas é importante ressaltar que o compromisso assumido com o PVC perpassa pela dimensão pedagógica do "pré" da preparação do vestibular, mas as motivações dos entrevistados coadunam com a questão da formação cidadã que transcendem os limites da sala de aula. 
Uma segunda questão apresentada nas entrevistas diz respeito às influências e/ou referências dos professores para atuarem como voluntários no PVC. Sendo esta também uma questão importante para a compreensão do processo de constituição do CPVCPSA.

\section{4 \\ Principais Influências e Referências dos Precursores do Curso Pré- Vestibular Comunitário Pompeia Santo Agostinho}

Histórias, nossas histórias. Dias de luta, dias de glória. (Charlie Brow Jr.)

A compreensão de como se deu o processo de constituição do CPVCPSA perpassa pela identificação das principais influências e referências dos precursores do PVC, pois essa questão coaduna com as motivações dos primeiros professores voluntários e com a própria história do PVC.

De acordo com as entrevistas realizadas, as principais influências e referências foram os fundadores que fizeram parte da primeira coordenação do "pré" e os primeiros professores voluntários CPVCPSA. Neste contexto, alguns depoimentos merecem destaque.

É referência... as pessoas, todas as pessoas aqui da época que eram professores e coordenadores sempre foram exemplos de pessoas que gostavam de ajudar os outros. Então essas pessoas Rafael Dias, a Heros mesmo, entre outros, Fabio, Adelton e assim por diante (...). Mas essas pessoas que foram a referência pra mim, de fazer a coisa funcionar e motivar a gente, trazer a gente pra perto e assim por diante. (Entrevistado D).

(...) minha mãe Heros é uma influência café com leite. Mas é uma pessoa que mais me influenciou até hoje, a querer ajudar os outros (....). Então, a maior influência que eu tenho é ela. Assim a pessoa que me motivou, e sempre que eu, às vezes, saia chateada com o aluno, porque era agressivo, e a minha mãe sempre falava que você tem que pensar também o que essa pessoa tem, não só dinheiro, mas em casa, falta de atenção. Então, ela é a pessoa que mais me influencia. (Entrevistado E).

Eu acho que a referência partia muito dos professores, eu tive bons professores, eu acho que a referência principal de luta foi a Heros, que era coordenadora e o Rafael, na época, era professor de Literatura (...) eu acho que tinha também uma questão muito interessante, que não era algo também que eles falavam assim, olha você tem que vir para cá ajudar, não era isso, acho que o próprio posicionamento deles, a maneira como eles lidavam com o trabalho e superando as dificuldades, acho que pelo menos para mim foi o principal até mesmo para criar outro pré-vestibular na região, então não tem como não, pelo menos na minha visão, não me referir a ele. (Entrevistado B). 
Desta forma, pode-se, então, perceber que as referências são lideranças da comunidade da Pompeia, isto é, as pessoas que idealizaram o projeto e que atuavam como coordenadores e professores voluntários. Neste contexto, a forma como conduziam o trabalho, ou seja, o posicionamento diante das questões do "pré" influenciavam outras pessoas, sobretudo os professores voluntários, a vontade de participar do PVC, por isso constatou-se que essas lideranças locais são as principais referências do CPVCPSA.

Outra liderança destacada por um dos entrevistados foi o padre da paróquia, pelo protagonismo e incentivo para o desenvolvimento do PVC, o Padre Antônio se tornou uma importante referência para os professores voluntários do CPVCPSA.

Olha, a primeira referência... eu não posso deixar de citar o Padre Antônio. Sempre foi uma pessoa que apoiou esse projeto. Ele tinha o desejo que esse projeto continuasse, acho que ele tinha a visão desse projeto, que era muito importante para a realidade da comunidade. (Entrevistado C)

O entrevistado acima apresenta a figura do padre da paróquia como um incentivador do PVC na igreja, ressaltando o seu apoio como fundamental para a continuidade do PVC. A visão do Padre de que o PVC era importante para a realidade da comunidade chamou atenção do entrevistado e esta atitude influenciou o mesmo na sua decisão de atuar como professor voluntário no CPVCPSA. Portanto, de acordo com o depoimento acima, pode-se constatar que o Padre Antônio foi uma referência importante para os precursores voluntários do CPVCPSA.

Conforme já mencionado, outro grupo que também foi destacado como referência - pela maioria dos entrevistados - é formado pelos primeiros professores voluntários do CPVCPSA, ou seja, parte do corpo docente também teve participação neste aspecto.

(...) Outra referência que eu tenho é que tive muita sorte aqui, foram os professores em especial. (...) Dos professores, vou citar o Fabio José, que saiu desse curso e fundou outro na paróquia próxima. Professores que sempre cativaram muito a gente. Como o professor Rodrigo de História, o próprio professor Leandro, que já é doutor professor em Física. Então, foram influências muito importantes que motivaram a voltar, foram referências importantes pra mim, até depois quando voltei a dar aula. Referência de 
postura e de comportamento na sala de aula. (...) São algumas referências que eu não posso esquecer. (Entrevistado C).

No tocante à questão das principais influências e referências dos precursores do CPVCPSA, pode-se então constatar que foram algumas lideranças do próprio PVC, isto é, coordenadores, o padre da paróquia e os professores voluntários, a postura na condução do trabalho e a forma como atuavam, o que os tornou exemplos a serem seguidos.

Não obstante a isso, no projeto da pesquisa, havia a hipótese de que os precursores do CPVCPSA tivessem como referências outros pré-vestibulares populares da época, como exemplo, o PVNC ou o EDUCAFRO, pois estes movimentos serviram de referência para muitos PVCs que surgiram nessa época, sobretudo os situados na região metropolitana do Rio de Janeiro. Entretanto não houve nenhuma menção a estes movimentos ou a quaisquer influências externas à comunidade da Pompeia.

É importante destacar que este estudo não tem como objetivo fazer uma comparação entre o CPVCPSA e outros grupos ou movimentos de educação popular, mas ressaltamos a importância que estes movimentos tiveram para o movimento de educação popular, principalmente a partir da década de 1990, para criação e consolidação de muitos núcleos de pré-vestibulares populares ou comunitários.

Ademais, de acordo com as entrevistas, pode-se perceber que não havia no CPVCPSA um trabalho específico de formação de novos quadros ou a preparação do aluno para militância. No entanto, as pessoas citadas pelos entrevistados tornaram-se referências dos professores voluntários, devido à forma como eles atuavam no PVC, e esta conduta fazia o efeito de agentes mobilizadores de voluntários para a causa do CPVCPSA.

Desta forma, constatou-se que o CPVCPSA é uma experiência local, com base comunitária e as referências são agentes sociais locais que atuavam na perspectiva da transformação da realidade da comunidade. Ainda assim, é possível perceber que a cultura da participação política na esfera "micro" também tem o alcance de resultados concretos, que servem de incentivo para inserção de novos atores na cena pública.

Segundo Santos: 
Essas manifestações simbióticas, onde o político aparece claramente transfigurado, onde agendas se cruzam e dialogam - de maneira não harmônica, e sim essencialmente conflituosa, mas sem que isso legitime a construção de instrumentos ou mecanismos institucionais de segregação ou expulsão - constituem espaços de agregação e convergência de indivíduos oriundos de segmentos sociais distintos, com atuações e envolvimentos distintos, portadores de valores e projetos societários diversos. Num ambiente social, onde os valores emanados pelas ideologias de base liberal apontam para a competição, individualismo e concorrência, emergem solidariedade e uma cultura de valorização da participação, associativismo e de obrigação social, onde os indivíduos buscam inserir-se em iniciativas que apontem para a superação do perverso quadro social. (2003: pág. 128).

Conforme esta referência e com base nos relatos das entrevistas, pode-se, então, perceber que o CPVCPSA é um espaço de participação política e de formação de novas lideranças, pois o trabalho desenvolvido no período de consolidação do PVC serviu de base para capacitação de novos educadores populares, que, por sua vez, deram continuidade às atividades do CPVCPSA - que já completou 15 anos de existência.

Uma terceira questão identificada nas entrevistas é quanto ao significado da participação dos professores voluntários no PVC. Essa é uma questão importante, que foi apresentada através de relatos e expressa como foi a experiência de fazer parte da história do CPVCPSA.

\section{5 \\ O Significado da Participação no Curso Pré-Vestibular Comunitário Pompeia Santo Agostinho - Uma experiência de vida}

É fundamental diminuir a distância entre o que se dize $o$ que se faz, de tal forma que, num dado momento, $a$ tua fala seja a tua prática. (Paulo Freire).

Ao perguntar qual o principal significado da participação para os professores voluntários, alguns aspectos foram destacados pelos entrevistados. Em primeiro lugar, o significado da formação profissional como professor, o segundo é referente à cidadania e o terceiro é a importância que o CPVCPSA teve na trajetória de vida dos professores voluntários. 
No tocante à formação profissional como professor, o fato de ter sido professor voluntário no PVC contribuiu para a formação profissional dos próprios entrevistados. Sobre este aspecto, algumas entrevistas merecem destaque.

Ter participado do Pré foi minha primeira experiência como professor e foi bem lá no Pré que eu tive a certeza que gostaria de continuar nesta profissão (...) Uma das coisas que eu aprendi, depois da minha experiência como professor voluntário, é o prazer de ensinar. De querer aprender mais para depois repassar. (Entrevistado A).

(...) Porque, quando eu comecei atuar lá, eu tinha 17 anos, eu passei com 17 anos, então, eu comecei a dar aulas no $1^{\circ}$ ano da universidade. Era um estágio, então, tinha que estudar, era obrigada a estudar, correr atrás e era muito legal, porque assim tinha que pesquisar. As pessoas sabiam que eu era nova e gostavam de testar de provocar mesmo, pra saber se eu estava sabendo as coisas. Os alunos "como é que uma pessoa de 17 anos vai dar aula para uma pessoa..." sei lá, tinha uma senhora que eu adorava, a dona Silvania, até hoje eu encontro com ela e ela fala "minha professorinha", ela tinha 60 e poucos anos (...). E me ajudou muita a dar aula, quando eu me formei, eu tinha tirado de letra, não tinha mais medo do aluno, do aluno me perguntar alguma coisa. Eu acho que me preparou para duas situações. Primeiro para o ensino público. Porque realmente o perfil dos alunos de lá eram do ensino público. Então você já esta preparado, não em relação ao comportamento, mas em relação ao aprendizado que aquele aluno não tem e precisa de você. (Entrevistado E).

Os entrevistados acima ressaltam a experiência de se tornar docente devido à atuação como voluntário no PVC e destacam esse espaço como lugar da primeira experiência profissional como professor. Todavia o Entrevistado E ressalta também o perfil dos alunos do "pré" como uma questão importante no processo de formação profissional, pois estes apresentam demandas singulares, que fazem do exercício da profissão um desafio ainda maior.

E, ademais, a questão do perfil dos alunos do PVC é algo que chama atenção, pois - conforme já destacado aqui - a atuação no PVC se deu no início da trajetória profissional desses professores, ou seja, eles ainda não tinham experiência como docente. Desta forma, as demandas trazidas pelos alunos do "pré" não se limitavam à questão do ensino e aprendizagem dos conteúdos curriculares, mas muitas vezes são questões relacionadas à realidade em que vivem esses alunos.

Segundo Santos (2005),

(...) Heterogeneidade dos alunos - é a tônica da composição do quadro dos prévestibulares populares. Heterogeneidade etária, de trajetórias escolares, de papéis sociais, de disponibilidade para o envolvimento com o curso, de visão política, etc. Os "prés" reúnem alunos que vêm de escolas públicas, cuja qualidade tanto pode ser boa 
como questionável, mas as condições sociais são predominantemente ruins. Mais do que isso, os pré-vestibulares populares têm como marca a busca da não-exclusão e com isso abraçam essa luta, alunos que há anos (e, muitas vezes, décadas) não têm qualquer contato com o estudo. São pessoas na faixa dos 40, 50 e, às vezes, até 60 anos que, apesar de não figurarem em estatísticas oficiais de exclusão universitária (os dados oficiais consideram apenas os jovens entre 17 e 24 anos), também se sentem excluídos da universidade, mas a tem como projeto de vida, que vai disputar espaço, em suas realidades, com os papéis de pai, mãe, dona de casa, trabalhador, chefe de família, etc. Ao requalificarem sua exclusão e serem inseridos no pré-vestibular, durante as aulas, esses alunos se juntam a jovens de 16, 17 anos, muitos deles recém-egressos dos bancos escolares, ou ainda concluindo o ensino médio. (2005; pág. 198).

Na citação acima, o autor ratifica a questão destacada pelas entrevistas quanto ao perfil singular dos alunos dos "prés" e ressalta este fator como um diferencial na formação de novos docentes. Desta forma, pode-se constatar que o fato dos entrevistados terem começado suas carreiras profissionais no PVC proporcionou uma bagagem profissional significativa, que estes carregam até hoje. Assim, a experiência como professores voluntários no CPVCPSA preparou os entrevistados para o enfrentamento dos desafios inerentes à profissão de professor.

Neste contexto, sobre a experiência da formação profissional, percebeu-se também que o PVC não tem como proposta somente formação pedagógica dos professores voluntários, mas tem como objetivo preparar esses professores para a busca de alternativas criativas para o exercício da docência. Essa questão pode ser observada no seguinte relato:

(...) A experiência de ter dado aula, ela significou, eu não gosto muito de falar essa palavra obrigação, retribuição, porque, assim, na verdade, assim em nenhum momento eles colocavam que a gente tinha que voltar para ajudar e foi uma coisa que eu levei comigo (...) mas eu acho que para mim era muito importante estar ali ajudando enquanto educador, enquanto futuro professor (...) acho que é um grande espaço de experiência, quer dizer, se eu for colocar assim, talvez das experiências que eu tive profissionalmente como professor, acho que é o espaço onde você tem mais liberdade para criar, não que não tenha regras, que você não tenha obrigações, tem muita gente que pensa dessa forma (...). Então, eu acho que é uma experiência onde eu pude aprender a ser professor, em primeiro lugar, (...) então, lá acho, assim, eu aprendi, acho que eu trilhei um pouco, errei também nesse processo no ser docente, no ser professor. (Entrevistado B).

O entrevistado acima ratifica que a experiência da iniciação profissional também foi o principal significado de ter participado do CPVCPSA e ressalta o PVC como um lugar privilegiado para dar os primeiros passos na docência, pois essa experiência marcou a sua trajetória profissional como educador. 
Uma questão destacada pelo entrevistado B merece especial observação, trata-se da autonomia que é dada pelos PVCs aos seus professores para criação de alternativas pedagógicas, para a prática da docência. Essa autonomia proporciona aos professores voluntários do "pré" uma formação diferenciada, para usar o termo utilizado pelo entrevistado B, "a experiência contribuiu na formação de educador". Neste contexto, Santos afirma:

\begin{abstract}
Além disso, os "prés" já funcionam como um espaço "real" de formação de educadores populares. Neles trabalham esses "novos" educadores (ainda em processo de formação acadêmica), assim como os que concluíram o curso superior, em uma experiência didático-pedagógica de interlocução com saberes populares. Isso lhes permite uma experiência de processo de formação, marcado por um pacto social distinto daquele que predominantemente ocorre em nossas escolas (porque a escola e a sala de aula são pactos sociais). E - devemos destacar - este processo de formação de professores é distinto daquele experimentado nos colégios de aplicação, principal referência de experiência de formação de novos docentes. Nossos colégios de aplicação são espaços de formação, onde o corpo discente é, predominantemente, de classe média, o que condiciona padrões característicos de uma escola pública comum. A experiência docência nos "prés" permite - ou melhor, exige - desse professor uma aproximação com os saberes dos alunos, para estabelecer um diálogo e conferir qualidade à formação. (...) Nesse sentido, os "prés" acabam sendo, mais do que um espaço de formação de professores, um lugar de formação de educadores populares! Educadores esses que se identificam com os alunos, neles se reconhecem e, por isso, se permitem valorizar seus saberes. Dos conflitos, das dificuldades e limitações, dos dilemas políticos, dos desafios pedagógicos, nasce o novo, o inovador. Das angústias cotidianas experimentadas por aqueles que constroem os "prés", nascem experiências inovadoras de inestimável riqueza, ainda que esta não seja percebida pelos próprios criadores. Sistematização e troca dessas experiências, bem como a discussão de sua natureza intrinsecamente política, passam a ser desafios fundamentais, para continuar e potencializar tais iniciativas. (2005; pág. 203).
\end{abstract}

Sendo assim, essa formação profissional diferenciada dos professores voluntários dos PVCs tem como representação o signo de "educador popular". Todavia não é redundante ressaltar a sútil diferença entre professor e educador, pois, nos PVCs, os professores voluntários das mais diversas disciplinas, como português, matemática, história, entre outras, não se limitam a trabalhar conteúdos pedagógicos desconectados da realidade de seus alunos e essa experiência concreta com o cotidiano desses alunos é o que os torna educadores diferenciados.

Desta forma, com base nas entrevistas destacadas aqui e a contextualização de Santos (2005), pode-se então constatar que um dos principais significados da participação dos professores voluntários no CPVCPSA é a formação profissional como 
professor de uma forma ampla, ou seja, a preparação para os desafios do exercício profissional.

Além disso, um segundo significado identificado nas entrevistas é em relação à cidadania dos entrevistados, pois esse aspecto foi ressaltado pela maioria dos entrevistados.

\begin{abstract}
A gente aprende muito enquanto pessoa vendo realidades de alunos tão distintos, vendo as dificuldades que eles apresentam e isso contribui muito para a formação de cidadania da gente. Eu tinha uma visão antes de participar do curso, até mesmo depois que passei pelo curso, eu tinha uma determinada visão, e quando comecei a dar aula essa visão muda. A gente vê que algumas realidades precisam de mais suporte, precisam de mais atenção, algumas coisas que são faladas assim como realidade, como coisas impostas, como a voz de massa também não são bem aquilo. E quando você entra em realidade de cada um em particular, que apresentam suas dificuldades, isso muda a gente enquanto pessoa, enquanto cidadão. Eu acho que essa foi a grande mudança, assim, em linha de divisão, realmente de que é um trabalho desses é importante, que esse trabalho precisa continuar ainda hoje mesmo com todas as facilidades do ENEM. (Entrevistado C).
\end{abstract}

O depoimento do entrevistado acima relata a mudança que ocorreu na sua vida a partir da experiência no CPVCPSA, pois o contato com as diversas realidades apresentadas pelos alunos do "pré" proporcionou a mudança da sua visão de mundo e da sociedade. Porém o significado de 'tornar-se cidadão' está relacionado com a construção coletiva da cidadania dos seus alunos. Percebeu-se, então, que a experiência deixa de ser individual e passa a ser coletiva, ou seja, a mudança não é apenas do indivíduo, mas as pessoas transformando-se juntas.

Já a cidadania - na perspectiva do Entrevistado C - está no compreender-se como cidadão através do olhar para os outros indivíduos e no reconhecimento desses indivíduos como portadores de direitos, ou seja, como cidadãos. E, ademais, esta perspectiva foi percebida a partir da atuação no CPVCPSA.

Em relação à questão da cidadania, essa questão também foi percebida no seguinte depoimento:

Foi engrandecedor. Vou dizer pra você, desse tempo todo de vida que eu tenho, acho que foi uma das melhores coisas que já fiz, assim, que foi ser professor de prévestibular comunitário. Então, eu olho pra trás e vejo várias experiências boas que eu tive de vida, tipo, tive a oportunidade de presenciar a pessoa com uma dificuldade, é uma situação difícil mesmo de vida da pessoa, e eu estava ali do lado contribuindo, mesmo que de uma forma bem pequena. Porque o mérito é $90 \%$ da pessoa, a força de vontade dela de querer vir batalhar e no final conseguir atingir o objetivo dela, que aqui 
no caso é o vestibular. Essas experiências, assim, são difíceis de descrever, mas que acrescentam bastante na sua vida. Acho que isso contribuiu muito para quem eu sou hoje como pessoa. Agradeço muito ao pré-vestibular por ter me dado essa oportunidade, desse momento de vida de várias pessoas. (Entrevistado D).

O significado para o entrevistado é em relação à contribuição da formação da cidadania dos seus alunos e isso contribuiu para sua formação pessoal, ou seja, essa experiência acrescentou valores à sua própria vida como pessoa humana e como cidadão. Neste contexto, percebe-se que o compreender-se cidadão está relacionado com a ação do entrevistado na sociedade para a construção da cidadania coletiva, mais especificamente no PVC.

Percebe-se também, nas entrevistas, a função política e social do CPVCPSA, pois o compromisso com a formação da cidadania coletiva é percebido na maioria dos depoimentos e está relacionado com a experiência de ter participado do PVC.

No tocante à questão da cidadania, os entrevistados destacaram também a visão política que o professor voluntário do PVC passa a ter a partir da experiência como docente no "pré".

Eu acho que é questão de responsabilidades, de você também ser responsável pelo crescimento da sua sociedade, acho que o pré-vestibular comunitário dá essa visão política, que talvez o pré-vestibular privado, talvez não tem essa preocupação. O prévestibular privado ele tem a obrigação de números de alunos sejam classificados. Não, eu não estou falando que os alunos do Pré-vestibular privado não vão poder ter posicionamento político, não vão ter talvez essa preocupação, mas acho que a gente tem uma vantagem, a gente que estuda em pré-vestibular comunitário e é professor de prévestibular comunitário, a gente começa com esse posicionamento mais cedo, porque é algo que é quase que é uma... eu estou falando por mim, né, mas pra mim foi algo quase que natural essa questão de me sentir também responsável pelo outro, também entender que eu também sou responsável pela sociedade, até em alguns momentos não só dentro da sala de aula, mas também na questão de ouvir o aluno, ouvir as demandas dos alunos (...) enfim, então são muitas demandas que te obrigam a estar ali com o aluno, não só na questão da preparação intelectual para o vestibular, mas acho que vai além, você conversar, de você procurar saber das histórias de vida de cada um deles, de uma certa maneira. (Entrevistado B).

O entrevistado acima destaca a função política do CPVCPSA, isto é, a missão de ampliar a visão de mundo dos alunos e a compreensão do seu papel na sociedade. No entanto amplia-se também a compreensão dos objetivos do PVC, que vai além de possibilitar o acesso dos seus alunos nas universidades, mas também trabalha a 
perspectiva crítica da sociedade como condição "sine qua non" dos pré-vestibulares comunitários e/ou populares.

Outra questão destacada pelo Entrevistado B é a diferença entre o PVC e os Prévestibulares privados, pois, de acordo com o depoimento acima, o PVC tem a preocupação com as demandas individuais de cada aluno. Neste sentido, há o rompimento com a cultura da competição pela disputa de vagas e em contrapartida há a valorização da perspectiva coletiva, o que significa formar cidadãos responsáveis uns pelos outros em uma sociedade que cada vez difunde mais o individualismo.

Neste contexto, o significado da cidadania não se restringe somente aos professores voluntários e aos alunos do CPVCSA, mas alcança toda a comunidade, conforme sinaliza o depoimento abaixo.

Olha, é uma sensação de dever cumprido. Digamos assim: De você contribuir para... na verdade, é uma utopia. Tenho essa utopia a partir desse projeto, a partir das nossas aulas, né, a gente consegue fazer com que o aluno ingresse na faculdade. Mas eu sempre pensei muito mais do que isso, meu objetivo enquanto professor aqui foi que o aluno se mantivesse na Universidade e concluísse. É aquela utopia a gente querer que a pessoa mude sua realidade de vida, como muitos mudaram, e isso mude a realidade de sua família, e muitos mudaram, e mude a realidade do bairro... e que mudou também. Então, essa utopia que a gente sente e que dá forças pra gente continuar também com esse curso (...). E, no geral, no segundo ponto é a própria motivação do curso como um todo. Você ter a retribuição do aluno de que o curso como um todo foi muito importante pra ele no processo. Que é um processo difícil, né, de reconhecimento de identidade, um processo difícil de escolha, né, e a gente sabe que fez parte. É claro que eu nunca acreditei que a gente fosse parte como ferramenta principal, mas como secundária, porque o principal é sempre a vontade do aluno, o empenho dele, a força que a família dá. Mas, mesmo como suporte secundário, a gente se sente muito orgulhoso no sentido de ter feito parte da construção da vida daquele cidadão. (Entrevistado C).

O relato da experiência pessoal do entrevistado é apresentado como significado da transformação da realidade local através da ação do PVC. Mas o entrevistado também ressalta que a cidadania acontece em primeiro lugar no âmbito individual, a partir dos alunos, depois essa mudança é ampliada e contempla a família, a comunidade e o bairro. Desta forma, a questão da cidadania é ratificada pela maioria dos entrevistados como um dos principais significados da participação no CPVCPSA.

Desta forma, é importante compreender a cidadania nos diversos aspectos em que é destacada pelos entrevistados, especialmente no tocante à educação como ferramenta para cidadania, pois esse foi um dos principais aspectos que os professores voluntários atribuíram ao CPVCSA. 
(...) E, assim, eu vejo que é uma constante, você sempre vai ter vontade de ajudar o outro de alguma forma, entendeu? Só que eu acho, pela educação é a maneira que você ajuda mais. Você pode da um quilo de não sei o quê, mas tem uma frase da minha professora lá da UFF, que ela sempre falava "a única coisa que ninguém tira de você é o conhecimento". Então, é o máximo que você pode dar pra pessoa. Entendeu? É isso, então, acho que só fez com que eu quisesse mais transformar o outro, entendeu? Até hoje é assim, eu vejo na minha vida como professora isso. (Entrevistado E).

O Entrevistado acima ressalta a educação como um mecanismo importante para formação da cidadania dos alunos do PVC, pois o compartilhamento do conhecimento possibilita que esses alunos alcancem seus objetivos e conquistem outros direitos de cidadania. Neste contexto, a educação é compreendida como porta de entrada para os demais direitos necessários para uma vida com dignidade, por isso que essa questão é bastante enfatizada pelos entrevistados.

Além do mais, a compreensão de cidadania - que é amplamente destacada pelos entrevistados - é a cidadania construída coletivamente e com o protagonismo de todos os atores sociais envolvidos no PVC, não se trata de uma cidadania concedida ou dada como benesse, mas sim conquistada com muita luta pelos participantes dos CPVCs Populares. Outrossim, percebeu-se que - para os entrevistados - a questão da cidadania é tão importante quanto a inserção dos alunos nas universidades.

Esta concepção de cidadania pela educação, a que se refere a Entrevistada E, remete a Paiva ao citar Bryan (1998), Santos (1995) e Roche (1987).

\footnotetext{
Atualizando o conceito de cidadania, Bryan Tunner (1988) vai defender a importância de se acrescentar fatores culturais e históricos à concepção evolucionista de Marshall, para que se possa interpretar a realização da cidadania nas distintas democracias modernas. Deve-se então falar de direitos culturais e de uma cidadania social, como propõe Boaventura Souza Santos (1995), no momento em que for possível a articulação entre a representação e a participação numa nova maneira de se fazer política. Mas em todas essas análises há um denominador comum: a necessidade da educação universalizada como fator diferenciador para o alcance da cidadania e da inteligibilidade das práticas discursivas. Se para Marshall a educação é o "pré-requisito" para sua concretização, Roche (1987) vai enfatizar que as políticas para ampliação de acesso à informação, à educação universalizada e aos meios de comunicação de massa vão ser "dimensões práticas cruciais da cidadania, em particular da cidadania social" (p. 381). A educação universalizada funcionou, assim, como a dimensão vital que possibilitou não só a maior participação social de grupos que até então não eram capazes de participar, como também (e condição para essa participação) o desenvolvimento cognitivo para a competência comunicativa, para usar um conceito habermasiano, para que a esfera pública burguesa pudesse ser, então, alargada. (Paiva: 2010; Págs., 20 e 21).
} 
A autora e a entrevistada destacam a educação como ferramenta fundamental de acesso à cidadania, isto é, como um direito preliminar para conquista de outros direitos de cidadania. Todavia corroboramos com Paiva (2010) quando a autora ratifica a importância da educação como direito fundamental que possibilita a participação social de novos grupos, os quais não tinham oportunidades de participar da cidadania social, ou seja, é a ampliação do universo pessoal e coletivo desses indivíduos.

Sendo assim, constatou-se, então, que para os entrevistados a cidadania representa a oportunidade de participação em diversos espaços da sociedade, como a universidade e outros espaços de construção do conhecimento, pois esse acesso - que foi historicamente negado a essa parcela significativa da população - limitava o direito desses indivíduos a uma cidadania plena.

Um terceiro aspecto destacado pelos entrevistados - como significado da participação no CPVCPSA - é em relação ao que representou na trajetória de vida dos professores voluntários, quer dizer, o que ficou de importante dessa experiência.

(...) Então, é a coisa que eu mais sinto falta, eu acho hoje em dia. De você, porque é muito legal quando você vê que um aluno não sabe, tem muita dificuldade e você ajudou. Mesmo que seja uma turma de vinte (20), mas você ajudou dois (2), aquilo ali preenche, sabe, mesmo não tendo salário. As pessoas dizem "ah, voluntariado", outro dia eu estava lendo que em outros países isso é muito mais comum, o voluntariado, do que aqui. Aqui a gente tem essa coisa... Pra mim, eu acho que preencheu assim, tem alunos que foram nossos alunos e que já estão na universidade, tem mestrado. Sabe e te encontra na rua e fala "nossa, eu fiz isso, fiz aquilo" e você sabe que é um grãozinho daquilo. Eu acho que é a maior recompensa. (Entrevistado E).

A Pompeia, o espaço pré-vestibular da Pompeia é o espaço que eu tenho muito carinho até hoje. Se hoje eu estou no doutorado, eu sempre falo isso, começou ali. (Entrevistado B).

(...) a trajetória de vida da gente é composta por vários fatores. E aí se eu tivesse que colocar, eu diria o seguinte: que o pré-vestibular, ele me deu a base ali, é o início de tudo. Então, toda a minha trajetória acadêmica de ensino superior começa ali. OK! É claro que o pré-vestibular poderia ter me ajudado no ingresso à universidade e, por exemplo, em algum momento futuro eu ter abandonado e ir fazer outra coisa, trabalhar por necessidade de grana. Porque é outro aspecto desse tipo. Mas o pré-vestibular não pode ser só objeto no meio da sua trajetória, ele está lá pra te ajudar com a base. Eu acredito que a base é o princípio de tudo. Tudo o que você vai fazer lá na frente, você precisa de algum tipo de suporte, e o pré-vestibular dá esse suporte pra quem não tem condições de arcar com as despesas de fazer um curso de pré-vestibular lá fora pago. Ok! Então, ele é a base disso aí. Quando você quantifica o fato de chegar aonde eu 
cheguei, eu sou doutor em física, Ok! Quanto o pré-vestibular contribuiu, eu não sei te dar uma quantidade exata, mas pra mim foi importante. (Entrevistado D).

Sendo assim, pode-se perceber nas entrevistas que ter participado do CPCPSA tem um significado importante em relação ao "Projeto de Vida" dos entrevistados. Entretanto percebeu-se também que essa experiência não representa somente a concretização dos "projetos individuais de vida" dos entrevistados, mas também a importância de contribuir para a realização dos projetos de vida dos alunos do PVC.

Desta forma, a experiência de ter sido professor voluntário tem como significado o sentimento do dever cumprido, pois ao perceberem os resultados concretos do PVC, ou seja, as trajetórias vitoriosas dos ex-alunos, isso tem a representação simbólica da recompensa pelo tempo de vida dedicado ao projeto.

Neste contexto, constatou-se que o CPVCPSA também serviu de "base" concreta para trajetória de vida exitosa dos entrevistados, haja vista que estes destacam a excelente formação acadêmica e profissional que alcançaram e atribuem esse êxito ao fato de terem como base o CPVCPSA.

Sendo assim, uma quarta questão destacada na entrevista é a importância do CPVCPSA no olhar dos protagonistas da história.

\title{
3.6
}

\section{A Importância do Curso Pré-Vestibular Comunitário Pompeia Santo Agostinho - O olhar dos seus protagonistas}

\begin{abstract}
De tudo, ficaram três coisas: a certeza de que ele estava sempre começando, a certeza de que era preciso continuar e a certeza de que seria interrompido antes de terminar. Fazer da interrupção um caminho novo. Fazer da queda um passo de dança, do medo uma escada, do sonho uma ponte, da procura um encontro. (Fernando Sabino).
\end{abstract}

As entrevistas destacadas neste estudo são carregadas de representações que fazem parte da história do CPVCPSA e, conforme já mencionado aqui, essa história se entrelaça com as histórias de vida dos protagonistas deste processo. Desta forma, os 
últimos relatos representam o sentido do CPVCPSA para os entrevistados, isto é, o que ficou de importante para os protagonistas da história, o que merece especial atenção.

Sendo assim, os entrevistados destacaram como sentido do CPVCPSA algumas questões que estes consideram importante: a continuidade e ampliação dos CPVCs; a importância de reconhecer o trabalho das pessoas que se dedicam aos PVCs; a gratidão e o reconhecimento aos professores, coordenadores que passaram pelo CPVCPSA ao longo desses quinze anos; e a compreensão que o PVC, ainda hoje, é uma referência importante para a região onde está situado.

Quanto à questão da continuidade e ampliação dos CPVCs, destaca-se o seguinte depoimento.

Olha, eu acho, e pela perspectiva que eu tenho hoje com a escola pública que era um projeto que nunca tinha que acabar, não deveria acabar. Todas as comunidades deveriam ter, todas as paróquias deveriam oferecer. Porque por mais que tenha esses setores de alimentos aí de ajudar as pessoas nessa parte, e como eu falei antes é a gente ajudar o outro com educação ainda é a melhor solução, entendeu? Se cada paróquia puder, não só paróquia, mas igrejas evangélicas, mas se pudesse oferecer isso para as crianças. (Entrevistado E).

O entrevistado enfatiza a importância do CPVCPSA no contexto da educação como ferramenta de transformação da realidade. Ao destacar que o projeto deve continuar com suas atividades, o entrevistado apresenta sua visão crítica sobre o ensino público e ressalta a importância da disseminação de outros Pré-Vestibulares Comunitários e cita, como exemplo, o CPVCPSA.

Conforme o relato apresentado, a questão ressaltada foi a necessidade da continuidade dos CPVCs - Populares. Entretanto percebeu-se que o entrevistado tem como perspectiva a ampliação dos pré-vestibulares comunitários, pois afirma que “(...) todas as paróquias deveriam oferecer (...) não só paróquias, mas igrejas evangélicas também (...)". Essa afirmação é bastante significativa e traz o contexto de que a educação ainda apresenta problemas que precisam ser superados.

No tocante à questão da educação, é importante reconhecer os avanços recentes, sobretudo em relação às políticas de acesso ao ensino superior no Brasil. No entanto não se pode negar que ainda existem muitas lacunas que precisam ser observadas, por isso a fala recorrente do entrevistado chama atenção para esta questão. 
Neste contexto, não é objetivo desse estudo fazer uma análise da educação brasileira na atualidade, mas pode-se perceber que para o entrevistado o PVC ainda é de suma importância para ampliar as possibilidades dos alunos oriundos das escolas públicas, que têm no ensino superior o caminho para mudar a realidade em que vivem.

Segundo Lucinda (2002):

A visão que os indivíduos têm ou vão ter da sociedade passa muito pela questão dos valores, da educação e da capacidade de avaliar a contribuição que pode oferecer em termos da construção de projetos coletivos. Esse tem sido um campo de lutas, que são travadas em diversas trincheiras e a meta esperada é a mudança, é a transformação ainda que em escalas menos ambiciosas. (Pág. 3).

Desta forma, constatou-se, então, que o PVC ainda é uma importante ferramenta de inclusão de alunos das comunidades periféricas e também para a construção de novos projetos societários, conforme os valores que são disseminados nos "prés" e que foram amplamente destacados pelos entrevistados nesse estudo.

Essa é uma questão importante do ponto de vista da pesquisa, porque ratifica a importância da continuidade dos CPVCs nos tempos atuais e também a criação de novos cursos, pois temos um número cada vez mais reduzido de "prés" de recorte popular ou comunitário.

No tocante ao sentido do reconhecimento do trabalho das pessoas que se dedicaram ao longo desses quinze anos ao CPVCPSA, temos o seguinte relato:

(...) $\mathrm{O}$ que eu poderia dizer do pré-vestibular, que às vezes a gente não comenta ou comente acreditando que comente pouco, e enfatizar que você montar um prévestibular, coordenar um pré-vestibular, você conseguir colher recursos tanto financeiro quanto humanos, que no caso são os professores que dão a vida do dia a dia do prévestibular é extremamente difícil. Eu nunca participei diretamente de nenhuma coordenação, mas sempre fui muito próximo dos coordenadores que estiveram aqui na Igreja da Pompeia e no pré-vestibular da São Francisco de Assis. Então eu vi que essas pessoas se dedicavam grande parte do tempo delas, às vezes mais tempo do que o próprio professor, os professores durante todo aquele tempo em sala de aula e o coordenador além de fazer e ter todas as atividades extraclasses, ele também estava presente no pré-vestibular durante as aulas pra ver como estava o andamento, como estava a evasão, se a turma estava muito cheia, coisas simples do dia a dia, como tem muito aluno, a gente está precisando de cadeira, a infraestrutura da sala está funcionando, como está a questão de energia elétrica, ventilador, etc. Todos esses pequenos detalhes que no final fazem a diferença. Isso dá um grande trabalho, quem é coordenador sabe do que eu estou falando. Então, muitas vezes a gente se esquece de fazer isso. Então, acho importante deixar meu respeito aqui, que eu só tenho a agradecer a todos os coordenadores que participaram do pré-vestibular, dos que 
participam atualmente, mesmo não fazendo parte, eu só queria reconhecer o trabalho dessas pessoas, que é um trabalho importante que eles... são a vida do pré-vestibular. Sem um bom coordenador, a coisa desanda. (Entrevistado D).

O depoimento do entrevistado acima expressa - em um primeiro momento sentimentos de gratidão e respeito pelos protagonistas da história do CPVCPSA. O entrevistado destaca também a importância de reconhecer o trabalho dos coordenadores do PVC, pois, na sua perspectiva, essas pessoas são os principais responsáveis pelo êxito do CPVCPSA.

Desta maneira, percebeu-se que o trabalho dos coordenadores e a maneira como eram tratadas as questões do cotidiano do PVC ficaram marcadas como um modelo de gestão diferenciado, isto é, a preocupação com a evasão dos alunos, o respeito aos professores, entre outros detalhes, é o que caracteriza o compromisso social do "pré" com as pessoas e com a comunidade.

Neste contexto, ao destacar os desafios enfrentados pela coordenação do CPVCPSA, o entrevistado reconhece a importância das pessoas que se dedicam para o bom funcionamento do PVC. Entretanto o respeito demostrado na entrevista remonta ao que a história do CPVCPSA representa para todas essas pessoas e também para a comunidade.

Dito isto, na maioria das entrevistas, predomina o sentimento de gratidão e respeito ao CPVCPSA, por tudo que esse projeto representa para os protagonistas dessa história. Sendo assim, referente ao sentido da gratidão aos professores e coordenadores do PVC, o relato abaixo destaca essas questões.

Agradecimentos, a gente tem muito a agradecer a todos esses que contribuíram. Foi importante para mim, foi importante para os alunos que passaram por aqui, todos os professores que por aqui passaram. Eu acho que eles merecem grande louvor, que esse pré-vestibular contribuiu para o desenvolvimento humano e de muitas pessoas e desse bairro também. Pessoas hoje que já têm mestrado e doutorado, cursando o doutorado. Posso citar aqui o Leandro que terminou lá fora, tem título de PHD. Passou por essas cadeiras como aluno, Fabio José que passou por essas cadeiras como aluno e hoje é professor e está cursando doutorado e fundou outro pré-vestibular e fundou um curso preparatório, a Gisele que hoje não está nem mais aqui no Brasil, foi para a França. Essas pessoas que tiveram suas vidas mudadas, do bairro, de suas famílias. Agradecer a todos esses profissionais que voltaram e contribuíram, agradecer aos nossos alunos que sempre foram pacientes conosco, com todas as falhas que um curso desse pode apresentar. Porque os professores muitas vezes ingressam inexperientes, muitos os que passaram por aqui como professores tiveram sua primeira experiência de docência aqui, eu me incluo aqui entre eles, apesar de nem ter uma carreira de docência propriamente 
dita, porque sou economista. Eu voltei para contribuir como docente numa disciplina de matemática. Então agradecer a todas essas pessoas e personalidades que passaram por aqui, Rafael, Pe. Antônio... passando por aqui, dando a sua contribuição. Acho que é isso! (Entrevistado C).

Ao expressar a gratidão para com os implementadores e professores do CPVCPSA, o entrevistado utiliza a sua fala para fazer a memória histórica das personalidades do PVC e ratifica a importância do projeto para a comunidade e para o bairro. Além disso, o entrevistado ressalta o "desenvolvimento humano" e as trajetórias exitosas das pessoas que passaram pelo "pré" como resultado qualitativo da ação do CPVCPSA.

No tocante ao que o CPVCPSA representa para o entrevistado, contatou-se que o que ficou de importante foi o sentido da transformação social ocorrida na comunidade, a partir da atuação dos precursores do CPVCPSA. E, ademais, merece destaque a ênfase que é dada às pessoas que contribuíram para a concretização do PVC, pois essas pessoas são consideradas como exemplos de que é possível chegar aonde se deseja, é o que Joaquim Barbosa (2011) chama de "personalidades emblemáticas".

(...) Vale dizer, os representantes de minorias que, por terem alcançado posições de prestígio e poder, serviram de exemplo às gerações mais jovens, veriam em suas carreiras e realizações pessoais a sinalização de que haveria chegada a sua vez, obstáculos intransponíveis à realização de seus sonhos e à concretização de seus projetos de vida. (...). (2011: pág. 137).

Neste contexto, com a constatação de que os precursores do CPVCPSA são "personalidades emblemáticas", isto é, “exemplos vivos de mobilidade social", é importante para ratificar o trabalho do CPVCPSA, pois, através deste projeto, percebese a mudança na perspectiva de vida das pessoas, das famílias e até mesmo da comunidade, conforme destaca o entrevistado.

Constatou-se, então, que os coordenadores e os primeiros professores voluntários são as "personalidades emblemáticas" do CPVCPSA e esse é um fato importante que ficou marcado, pois a maioria dessas personalidades são ex-alunos do PVC, que regressaram como professores voluntários e, desta forma, tornaram-se exemplos vivos do compromisso do CPVCPSA com seus alunos e com a comunidade. 
Outra constatação do que representa o CPVCPSA é no sentido de compreender o PVC como uma referência para a região e como um espaço importante de abrir caminhos, conforme destacou o entrevistado abaixo.

(...) É um espaço de respeito que eu tenho, de motivação, assim, que eu fico muito feliz, é no ano passado, um curso que no ano passado completou 15 anos, então é um curso que ainda continua com suas atividades, ainda é uma referência muito grande para a região, então, acho que a consideração que eu faço, que eu desejo que esse curso continue durante bastante a possibilitar, a gente sabe hoje dia que é uma questão totalmente diferente, talvez da época que eu entrei em 2002, porque eu acho que mudou muita coisa nessa questão ao acesso à universidade, então, hoje em dia tem muitas políticas que estão de uma certa maneira motivando, pode ter suas críticas, mas acho que ampliou bastante o acesso ao ensino superior, eu não sei, eu percebo que talvez, eu não sei se a procura hoje está tão grande como antigamente, pelo fato de hoje em dia de você ter muitos mecanismos para o ingresso na universidade. Então, mas mesmo assim eu considero que o Pré-vestibular da Pompeia é um espaço para mim importantíssimo para a região de abrir caminhos, eu sempre penso na questão da Pompeia como foi na minha vida, porque eu não sei talvez se eu não passasse naquele ano, o que seria? Será que eu seria professor universitário? Será que eu estaria no doutorado? Sinceramente eu não sei, talvez sim, talvez não, mas que bom que aconteceu naquele ano, naquele espaço, naquele momento. (Entrevistado B).

O entrevistado acima ressalta o sentido do CPVCPSA, que na sua perspectiva merece todo respeito e admiração pela trajetória histórica desse PVC, e este depoimento é muito importante para elucidar o que representa o CPVCPSA para a região onde o projeto é desenvolvido, desde sua fundação até os dias atuais.

Ele também destaca que o PVC é "uma referência muito grande para a região”. Todavia é importante ressaltar que - além da questão afetiva demostrada no depoimento acima - percebeu-se também que o entrevistado ratifica a importância da continuidade do CPVCPSA, pois na sua percepção trata-se de "um espaço de abrir caminhos", de criação de novas possibilidades e perspectivas.

Outra questão identificada no relato acima é referente à demanda atual dos "prés" e à necessidade da continuidade dos CPVCs, pois o entrevistado ressalta o avanço das políticas de acesso às universidades. Visto que as políticas de ação afirmativa, como acesso ao ensino superior, de fato ampliaram o número de alunos oriundos dos "prés" nas universidades, porém sendo esta ainda uma questão importante a ser aprofundada, isto é, se a conquista de tais políticas significou realmente a superação de toda a demanda dos CPVCs - Populares.

Segundo Joaquim Barbosa: 
Tal estado de coisas conduz a duas constatações indisputáveis. Em primeiro lugar, à convicção de que proclamações jurídicas por si sós, sejam elas de natureza constitucional ou de inferior posicionamento na hierarquia normativa, não são suficientes para reverter um quadro social que finca âncoras na tradição cultural de cada país, no imaginário coletivo, em suma, na percepção generalizada de que a uns devem ser reservados papéis de franca dominação e a outros, papéis indicativos do status de inferioridade, de subordinação. Em segundo lugar, ao reconhecimento de que a reversão de um tal quadro só é viável mediante a renúncia do Estado à sua histórica neutralidade em questões sociais, devendo assumir, ao revés, uma posição ativa, até mesmo radical se vista à luz dos princípios norteadores da sociedade liberal clássica. (pág. 134).

A análise contextual do jurista Joaquim Barbosa é importante para se compreender que as políticas de ação afirmativa, por si só, não são suficientes para superação de um quadro historicamente enraizado, com marcas profundas de desigualdades sociais. No entanto não se trata de fazer a negação dos avanços e conquistas das políticas já mencionadas aqui, mas de compreender que ainda é muito cedo para avaliar a consolidação das políticas de ação afirmativa para o ensino superior como superação da demanda dos PVCs.

Não obstante isso, a ação dos CPVCs é de fundamental importância para as comunidades periféricas, pois ainda existe uma demanda significativa nesses lugares. Todavia, de acordo com a entrevista, pode-se constatar a importância da continuidade do CPVCPSA e, de acordo com alguns relatos da pesquisa, é ressaltada a necessidade de criação de novos núcleos.

Neste contexto, a questão destacada na entrevista merece um estudo mais aprofundado e uma análise dos avanços e entraves das políticas de ação afirmativa no Brasil e o papel dos CPVCs - Populares no contexto atual. Entretanto não é objetivo deste estudo fazer a análise mais aprofundada dessas questões.

No que diz respeito à importância do CPVCPSA para o Entrevistado B, pode-se constatar que foi importante para sua trajetória pessoal, isto é, suas conquistas nos campos acadêmico e profissional, pois o PVC representa o começo de sua trajetória. Além disso, percebeu-se também que o CPVCPSA tem grande importância para a região onde fica localizado e por ser uma referência local.

Desta forma, constatou-se nas entrevistas que a visão dos protagonistas do CPVCPSA é a representação da importância que este projeto tem para a trajetória de vida dos entrevistados. Sendo a história do CPVCPSA permeada de resultados 
concretos no tocante à realização de "projetos de vida" dos entrevistados e também para o desenvolvimento humano local, por isso foram observadas várias manifestações de sentimentos, como gratidão e reconhecimento.

Enfim, é importante ratificar que a quase totalidade dos entrevistados ressaltaram a importância da continuidade das atividades do CPVCPSA e a função social e política do "pré". Desta forma, as possibilidades criadas a partir deste PVC foram destacadas durante toda a pesquisa, pois este projeto tem um grande significado para as pessoas da comunidade da Pompeia e para os moradores do bairro de Ricardo de Albuquerque.

Para uma análise mais aprofundada deste tema, é necessário considerar outras questões que não cabem neste estudo, mas, em primeira instância, com base na observação empírica dos anos de atuação no CPVCPSA, é possível afirmar que a procura é menor do que há uma década. Neste contexto, corroborando com o depoimento do entrevistado acima, os mecanismos criados pelas políticas de ação afirmativa possibilitaram um maior acesso da "clientela" dos PVC. Entretanto não há como afirmar que as políticas de ação afirmativa superam as demandas dos CPVCs Populares. 


\title{
4 \\ Considerações Finais
}

\begin{abstract}
Eu queria agradecer também você ter me convidado para participar dessa entrevista, da oportunidade de eu dar meu ponto de vista a respeito dos acontecimentos. (Entrevistado D).
\end{abstract}

A tarefa de fazer o processo de constituição do Curso Pré-Vestibular Comunitário Pompeia Santo Agostinho - CPVCPSA foi importante no sentido de fazer a memória histórica da gênese, reconhecer o trabalho dos precursores desse projeto e para ratificar a importância que esse PVC ainda tem para a comunidade da Pompeia, mesmo após 15 anos de funcionamento. Neste contexto, algumas questões importantes foram destacadas pelos entrevistados acerca dos significados do CPVCPSA, isto é, representações simbólicas que constituem a trajetória histórica desse importante projeto de educação popular.

O CPVCPSA traz no nome a marca da comunidade da Pompeia e este é um dos significados mais importantes desse estudo, haja vista que o sentimento de pertencimento a essa comunidade está relacionado à motivação dos professores voluntários para atuarem no PVC.

Desta forma, é importante considerar o aspecto comunitário como uma característica que define o que é o CPVPSA e como este projeto se consolidou ao longo dos seus 15 anos de atividades initerruptamente. Sendo assim, percebeu-se que a comunidade da Pompeia é a base de sustentação do PVC e o apoio que a paróquia oferece para realização deste trabalho tem ajudado muito na continuidade deste trabalho.

Sendo assim, a criação de laços afetivos e o estabelecimento de vínculos entre as pessoas que atuaram no PVC reforçaram o sentimento de pertencimento à comunidade $\mathrm{e}$ também serviram de motivação para que os primeiros professores voluntários atuassem durante bastante tempo no CPVCPSA. Neste contexto, o fato dos entrevistados reconhecerem a importância do PVC para o desenvolvimento da comunidade da Pompeia serviu também para que estes se sentissem como responsáveis pela continuidade do CPVCPSA, por isso regressaram para o "pré" como professores voluntários. 
Neste contexto, os precursores do CPVCPSA identificaram algumas lideranças locais, pessoas da própria comunidade da Pompeia, como as principais referências que influenciaram os primeiros professores voluntários. Este dado também é significante para considerarmos que o CPVCPSA é uma iniciativa local e sua ação é na perspectiva da promoção humana e do desenvolvimento da comunidade.

A história do CPVCPSA é composta por muitos significados, que foram destacados pelos entrevistados e apresentados ao longo desse estudo. Todavia vale ressaltar a "cidadania" como um aspecto que representa a síntese dos significados que o PVC deixou nos protagonistas dessa história.

Considera-se aqui a cidadania no sentido amplo da palavra, isto é, a "cidadania plena", construída coletivamente com a participação de todos os atores sociais envolvidos neste processo. Sendo que o processo de construção da cidadania dos entrevistados se deu de forma dinâmica, isto é, na relação direta com os outros indivíduos. Neste sentido, a cidadania é apresentada pelos entrevistados como signo do "ser", ou seja, atuar no CPVCPSA significou transformar-se em cidadãos através da prática cotidiana do "ser" em benefício dos outros indivíduos e da comunidade.

Não obstante, considera-se aqui a noção de "nova cidadania" e do "direito a ter direitos" (Dagnino, 1994). Este conceito é um contraponto à lógica "estadania", destacada por José Murilo de Carvalho (2011), pois no caso do CPVCPSA, pode-se constatar o protagonismo dos atores sociais do PVC na conquista da própria cidadania, simbolizada pelo direito ao ensino superior como porta de entradas a outros direitos de cidadania.

Interessante ressaltar que a cidadania aparece também, nas entrevistas, no sentido da profissão de professor, isto é, CPVCPSA serviu como um espaço de formação de professores ou uma espécie de estágio que significou a primeira experiência como docente. Vale também destacar que as ações do "pré" não são restritas à parte pedagógica de ensinar conteúdos cognitivos necessários para o exame do vestibular, mas existe um trabalho complementar, que leva em consideração a realidade social de cada aluno e busca a compreensão das dificuldades apresentadas por cada indivíduo. Neste contexto, o CPVCPSA imprimiu nos professores voluntários a identidade de "educadores populares" nos termos em que acentuou Paulo Freire (2011) e que transcende a formação profissional para a formação da cidadania plena. 
Outro aspecto significante, considerado nesse estudo como importante, é o fato dos precursores do CPVCPSA serem percebidos como "personalidades emblemáticas", pois são exemplos vivos de mobilidade social e também são testemunhas reais da eficácia da ação do PVC, pois essas próprias "personalidades emblemáticas" regressaram ao CPVCPSA - como professores voluntários - para dar testemunho de que é possível construir uma trajetória de vida bem sucedida e mudar a própria realidade, da família e da comunidade. Contudo, para que os projetos individuais de vidas sejam concretizados, é preciso trabalhar coletivamente para que outros também possam chegar aonde eles chegaram.

Desta forma, sobre o que ficou de importante do CPVCPSA para os entrevistados, foi a importância da continuidade das atividades do PVC. Os relatos finais dos entrevistados foram no sentido de sublinhar a história do CPVCPSA, que deve ser divulgada para que este projeto seja valorizado e para que seja dado o devido reconhecimento para as pessoas que ajudaram a construir essa trajetória de sucesso.

Neste contexto, uma questão que foi apresentada merece ser aprofundada em outros estudos: é o fato de ainda haver necessidade de CPVC ou Populares, apesar de que as políticas de ação afirmativa aumentaram significativamente o acesso de pessoas pobres no ensino superior.

Essa questão foi identificada ao longo desse estudo e, por isso, é importante que seja feita uma análise mais profunda desses fatores, pois, nas referências pesquisadas, pode-se concluir que o número de pré-vestibulares é menor do que há 15 anos. Entretanto, nesse estudo, não houve - como objetivo - produzir elementos para compreensão dos rebatimentos das políticas de ação afirmativa nos CPVCs - Populares.

Enfim, o depoimento que abre esse capítulo parece despretensioso, mas é tão importante quanto todos os depoimentos apresentados neste estudo, pois representa a vontade do entrevistado de tornar pública a história do CPVCPSA e essa vontade foi percebida em todos os entrevistados, haja vista que os depoimentos direcionados ao CPVCPSA quase sempre expressaram sentimentos, como carinho, gratidão, reconhecimento, retribuição, entre outros. Portanto, acredito que esse estudo presta um serviço à sociedade por contar a História e os Significados do Curso Pré-Vestibular Comunitário Pompeia Santo Agostinho na Perspectiva dos Precursores. 


\section{Referências bibliográficas}

ALVAREZ, Sônia. DAGNINO, Evelina e ESCOBAR, Arturo (org). Cultura e Política nos Movimentos Sociais Latino-Americanos. Ed. CFMG. Belo Hirizonte. 2000 .

BENEVIDES, Maria, Victoria. Cidadania e Direitos Humanos. Ed. IEA/USP. São Paulo.

BOFF, Leonardo (Org). a Teologia da Libertação Balanços e Perspectivas. Ed. Ática. São Paulo. 1996.

BRANDÃO, Carlos, Rodrigues. O que é Educação Popular. Ed. Brasiliense. São Paulo. 2006.

CARVAlHO, José, COSTA, Renato e FILHO, Hélcio. Cursos Pré-vestibulares Comunitários - Espaços de mediações pedagógicas. Ed. PUC-RIO. Rio de Janeiro. 2005.

CARVAlHO, José, M, de. Cidadania no Brasil - O longo caminho. Ed. Civilização Brasileira. Rio de Janeiro. 2011.

CARVALHO, José, Sérgio. Educação, cidadania e direitos humanos. Ed. Vozes. Petrópolis. 2004.

CNBB. Diretrizes Gerais da Ação Evangelizadora da Igreja no Brasil - 2008 2010. Documento 4. Editora CNBB. Brasília. 2008.

DAGNINO, Evelina. Os Anos 90: Política e Sociedade no Brasil. Ed. Brasiliense. São Paulo. 1994.

FREIRE, Paulo. Educação como Prática da Liberdade. Ed. Paz e Terra Ltda. Rio de Janeiro. 2011.

GIL, Antônio, C. Métodos e Técnicas de Pesquisa Social. Ed. Atlas S.A. São Paulo. 1999. 
GOHN, Maria da Glória. Teoria dos Movimentos Sociais: paradigmas clássicos e contemporâneos. São Paulo: Loyola, 1997.

GOMES, Joaquim. A recepção do Instituto da ação afirmativa pelo Direito Constitucional brasileiro. Revista de Informação Legislativa. Brasília, 2001.

LEITE, Robson, de. O Alfabeto da Cidadania. Editora Mundo e Missão. São Paulo, 2013.

LUCINDA, Maria da Consolação. Novamérica. (2002) "Sociedade, Direitos Humanos e Cidadania: Desafios para a educação no Brasil. Relatório de Pesquisa. Candau, V.M. (Coord).

MINAYO, Maria Cecília de Souza. Pesquisa Social teoria, métodos e criatividade. $14^{a}$ Edição. Ed. Vozes.

MOELHLECKE, Sabrina. Ação Afirmativa: História e Debates no Brasil. Cadernos de Pesquisa No. 117, novembro de 2002.

NASCIMENTO, A. do. O movimento dos Cursos Pré-Vestibulares para Negros e a Política de Cotas nas Instituições de Ensino Superior. Cadernos Imbondeiro. João Pessoa, v.2, n.1, 2012.

PAIVA, A. R. Ação afirmativa na Universidade: reflexão sobre experiências concretas. Brasil-Estados Unidos. Rio de Janeiro: Editora PUC, 2004.

PASTORAL DA JUVENTUDE. Plano Trienal - 2005 - 2007. Vamos fincar nosso pé e fazer a nossa História. Centro de Capacitação da Juventude - CCJ. São Paulo, 2005.

PIOVESAN, Flávia. Direitos humanos e o direito constitucional internacional. São Paulo: Max Limonad, 1996.

SALVADOR, Andreia Clapp. A Gênese da política de ação afirmativa da PUC-RIO. Uma parceria entre Universidade e Movimento Social. Rio de Janeiro. Ed. PUC-RIO, 2008.

Ação Afirmativa na PUC-Rio: a inserção de alunos pobres e negros. Ed. PUC-Rio, 2011.

SANTOS, R.E. Racialidade e novas formas de ação social: o pré-vestibular para negros e carentes. In: SANTOS, R.E; LOBATO, F. (Orgs.). Ações afirmativas - políticas públicas contra desigualdades raciais. Rio de Janeiro: DP\&A, 2003. 


\section{6}

Anexo 1: Roteiro De Entrevista

Pontifícia Universidade Católica do Rio de Janeiro.

Departamento de Serviço Social.

Programa de Pós-Graduação - Mestrado

Disciplina: SER 3000 - Dissertação de Mestrado

Professora/Orientadora: Andréia Clapp Salvador

Aluno: Julio Mendes de Assis

ROTEIRO DE ENTREVISTA

Entrevistado (a) $\mathrm{n}^{\circ}$

Data

Ano de inserção no Pré-Vestibular Comunitário da Pompeia?

1) Dados Pessoais

a) Idade

b) Sexo

c) Qual a sua cor ou raça?

d) Localidade/Bairro em que morava no período do Pré-Vestibular Comunitário?

e) Você trabalha? Em que?

f) Qual a sua escolaridade?

g) Qual a sua religião?

2º) Sobre a inserção no Pré-Vestibular Comunitário da Pompeia

a) Quando você ingressou no Pré-Vestibular Comunitário da Pompeia qual era a sua função? Em que ano foi? Você ainda continua até os dias de hoje?

b) Como você ficou sabendo do Pré-Vestibular Comunitário da Pompeia?

c) Quais foram os motivos que levaram você a ser voluntário no Pré-Vestibular Comunitário da Pompeia? 
d) Quais as referências ou influências que levaram você a participar do PréVestibular Comunitário da Pompeia?

e) Quando você ingressou como voluntário no Pré-Vestibular Comunitário qual era a sua formação?

\section{0) Sobre a Experiência no Pré-Vestibular Comunitário da Pompeia}

a) O que significou pra você ter participado como voluntário no Pré-Vestibular Comunitário da Pompeia?

b) Você foi aluno do Pré-Vestibular Comunitário da Pompeia? Se sim, o que motivou você a regressar como voluntário?

c) Que mudanças você percebe na sua vida após a sua participação como voluntário no Pré-Vestibular da Pompeia?

d) $\mathrm{Na}$ sua perspectiva, quais foram os fundadores do Pré-Vestibular Comunitário da Pompeia? 


\section{Anexo 2: Apêndice A}

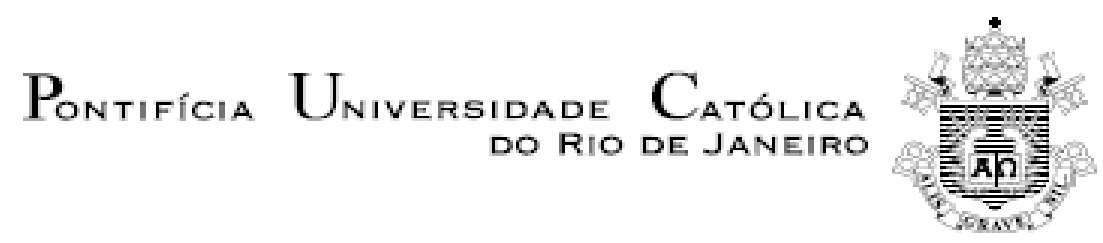

\section{TERMO DE CONSENTIMENTO LIVRE E ESCLARECIDO}

\section{Pesquisa: Pré-Vestibular Comunitário Pompeia Santo Agostinho: História e Significados na Perspectiva dos Precursores.}

Prezado (a), você está sendo convidado (a) para participar da pesquisa intitulada "Pré-Vestibular Comunitário Pompeia Santo Agostinho: História e Significados na Perspectiva dos Precursores." de responsabilidade do pesquisador Julio Mendes de Assis, mestrando vinculado ao Programa de Pós-Graduação em Serviço Social da Pontifícia Universidade Católica do Rio de Janeiro (PUC - Rio), orientada pelo Profa. Dra. Andréia Clapp Salvador.

O projeto de pesquisa apresenta como objetivo principal a compreensão do processo de constituição histórica do Pré-Vestibular Comunitário Pompeia Santo Agostinho.

Sua contribuição é de extrema importância para o desenvolvimento desse estudo, caso concorde em participar da pesquisa, desde já esteja ciente que suas respostas serão tratadas de forma anônima e confidencial, isto é, em nenhum momento será divulgado o seu nome em qualquer fase do estudo. Os resultados serão apresentados em conjunto, não sendo possível identificar os indivíduos que dele participaram, assegurando seu anonimato. As pessoas, por acaso, referidas durante a entrevista também terão suas identidades mantidas em sigilo. Os dados coletados serão utilizados apenas nesta pesquisa e os resultados divulgados em eventos e/ou revistas científicas.

A sua participação é voluntária, isto é, a qualquer momento você pode recusar-se a responder qualquer pergunta ou desistir de participar e retirar seu consentimento. Sua recusa não trará nenhum prejuízo em sua relação com o pesquisador ou com a instituição.

As entrevistas serão gravadas, e posteriormente, será realizada a transcrição das mesmas. O conteúdo das entrevistas, armazenados em arquivo, será destruído após 5 anos do término da pesquisa. Sua participação não importará em nenhum custo ou quaisquer compensações financeiras. 
A devolução dos resultados desta pesquisa ocorrerá através de sua apresentação no Pré-Vestibular Comunitário Pompeia Santo Agostinho.

Você receberá uma cópia deste termo onde consta o telefone/ e-mail e o endereço do pesquisador principal, e demais membros da equipe, podendo tirar suas dúvidas sobre o projeto e sua participação, agora ou a qualquer momento.

$\mathrm{Eu}$ abaixo assinado (a) concordo em participar voluntariamente desta pesquisa. Declaro que li e entendi todas as informações referentes a este estudo e que todas as minhas perguntas foram adequadamente respondidas pela equipe da pesquisa.

(Assinatura do entrevistado)

(data)

(Nome do pesquisador)

(data)

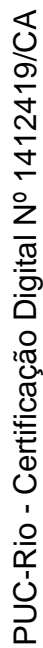

Telefone do mestrando do curso de Serviço Social da Pontifícia Universidade Católica do Rio de Janeiro Julio Mendes de Assis: 21/995329448. E-mail: juliopjleste1@gmaill.com

Telefone do orientador Profa. Doutora da Pontifícia Universidade Católica do Rio de Janeiro Andréia Clapp Salvador: 21/3527-1290. E-mail: aclapp@ puc-rio.br 